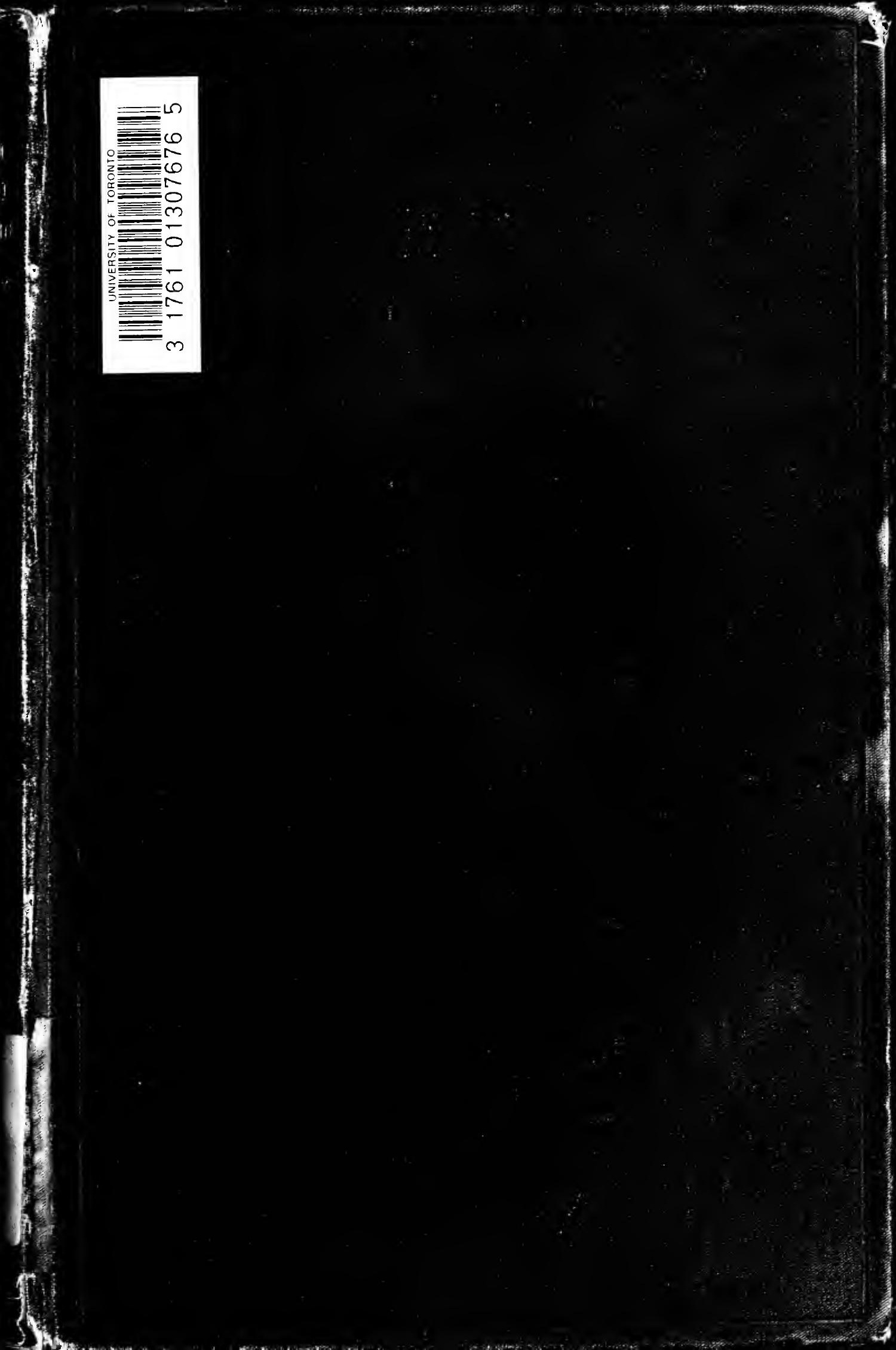


$\checkmark$ 
Digitized by the Internet Archive in 2008 with funding from Microsoft Corporation 
THE COLONIAL POLICY OF WILLIAM III IN AMERICA AND THE WEST INDIES 


\section{CAMBRIDGE UNIVERSITY PRESS}

C. F. Clay, Manager

LONDON : FETTER LANE, E.C. 4

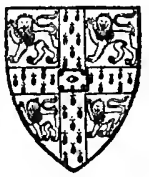

NEW YORK : THE MACMILLAN CO. BOM BAY

$\left.\begin{array}{l}\text { CALCUTTA } \\ \text { MADRAS }\end{array}\right\}$ MACMILLAN AND CO., LTD.

TORONTO : THE MACMILLAN CO. OF

CANADA, LTD.

TOKYO : MARUZEN-KABUSHIKI-KAISHA

ALI. RIGHTS RESERVED 


\title{
1114 COLONIAL POLICY OF WILLIAM III \\ IN AMERICA AND THE WEST INDIES
}

\author{
BY \\ G. H. GUTTRIDGE \\ Scholar of St John's College, Cambridge
}

S5

PRINCE CONSORT PRIZE ESSAY

I 922

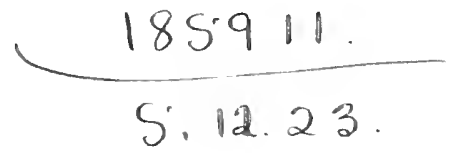

CAMBRIDGE

AT THE UNIVERSITY PRESS

I 922 
PRINTED IN GREAT BRITAIN 


\section{PREFACE}

THE period from 1689 to 17 I 4 in Colonial history has received 1 a far smaller proportion of consideration than those periods immediately preceding or following it; and yet it would appear likely that the years which saw the Revolution and the establishment in England of a new dynasty, with important foreign connections and important constitutional significance, should bear in colonial development a share at least equal to those periods considered at greater length. This essay is therefore designed to form the beginning of a link between the historical consideration of the Restoration colonial policy and that of the years prefacing the separation. One of the main difficulties in considering colonial policy before the War of Independence lies in the fact that there are few outstanding events which can be taken as starting points for investigation; and in this respect the possibilities of the Revolution of 1689 appear hitherto to have been overlooked. In the matter of point of view from which events have been treated I can therefore claim originality. Starting from the assumption-which the work of distinguished historians, especially the late Mr G. L. Beer, has clearly established-that the Navigation Laws formed the basis of English colonial policy, at least to the end of the seventeenth century, I have attempted here to examine the part played in colonial development by the Revolution of 1689 and the establishment of the new monarchy in England; and also to ascertain the general trend of progress in colonial relations during the period, wherever the Revolution and other noteworthy events of the reign afford special opportunity. The study thus involved has resulted only in an increasing conviction of the importance of the period.

The materials on which this essay is based are mainly provided by the Colonial State Papers, preserved in the Public Record Office and calendared under the editorship of the Hon. J. W. Fortescue and Mr Cecil Headlam. I have found by experience that for ordinary purposes of historical construction 
the Calendars give the information required although there is at least one occasion in which an important document is entirely omitted (i.e. the Board of Trade Report of I701); but the original documents have been consulted in the most important instances, as also other relevant manuscript authorities preserved in the Record Office and at the British Museum, whilst referncee has frequently been made to treatises and pamphlets of the period, in the above collections and in the Cambridge University Library. Some of these, as also the secondary authorities of importance, have been classed together in the bibliography which forms an appendix to this essay.

In dealing with a subject of such breadth, considerable use has necessarily been made of those secondary authorities which have touched on the events of William III's reign, or dealt at length with neighbouring periods of colonial history. In this connection, I have been specially indebted to G. L. Beer's Old Colonial System, for the economic situation prior to 1689 , to O. M. Dickerson's American Colonial Development, for the history of the Board of Trade from 1696 to 1765 , and to Francis Parkman's series dealing with the French in Canada, especially the volume entitled Count Frontenac and New France under Louis XIV.

I have added copies of three maps constructed during or within a few years of the period in question; and also, as appendices, matter dealing with colonial administrative method and with the state of population in the colonies.

For the original suggestion which led to an essay on this subject I must express my gratitude to $\mathrm{Mr} \mathrm{H}$. W. V. Temperley; whilst to $\mathrm{Mr}$ E. A. Benians I am especially indebted for much helpful criticism and suggestion.

G. H. G.

Cambridge,

August, 1922. 


\section{CONTENTS}

CHAP.

PAGE

I. INTRODUCTORY • • • • • • . I I

II. THE REVOLUTION OF I689 IN THE COLONIES

(a) The Revolution in New England • . . 13

(b) The Revolution in New York • • • . 26

(c) The Revolution in Maryland . . . . 32

(d) The Quieter Colonies • . . . . . 36

(e) The Colonial Importance of the English REVOlution . . . . . . . . 40

III. THE WAR WITH FRANCE IN NORTH AMERICA

(a) The Declaration of War a . . . . 44

(b) Defence and Offence on the Mainland 1689-93 47

(c) The War in the West Indies . . . . . 59

(d) Defence in America 1693-7 . . . . . 74

(e) The Interval of UnRest I697-1702 • . . 83

( $f$ ) The West Indies 1697-1702 • • • • 92

$\checkmark(g)$ Conclusions . . . . . . . . . 95

IV. THE POLITICAL ASPECTS OF COLONIAL POLICY

(a) Colonial Administration a $\quad$ • $\quad$ • 99

(b) The Period of Phips and Fletcher . . . 103

(c) The Southern Colonies . . . . . . I I I

(d) The Period of Bellomont • . . . . I I 7

(e) The West Indian Governments . . . I3I

$(f)$ The Political Situation a . . . . 146 
CHAP.

V. THE ECONOMIC ASPECTS OF COLONIAL POLICY

(a) The Navigation System • • • • • • I5O

(b) The Defects of the System and of Its AdMINISTRATION • • • •

(c) The Trade Laws and Scottish Activity . . 170

(d) The Economic Development of the Colonies . 173

CONCLUSION APP.

A. Select Bibliography • • • • • • $\quad$ - 182

B. An Example of Administrative Method • • . 184

C. The Population of the Colonies ․ . • • 185

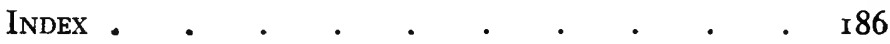

\section{MAPS}

I. The North American Continent i696 (Sauson, Atlas

Nouveau) . . $\quad$. $\quad$. . . . . . I

2. The American Colonies about i 7 ro (Mole, Atlas) 44

3. The West Indian Islands 1696 (Sauson, Atlas Nouveau) 132 


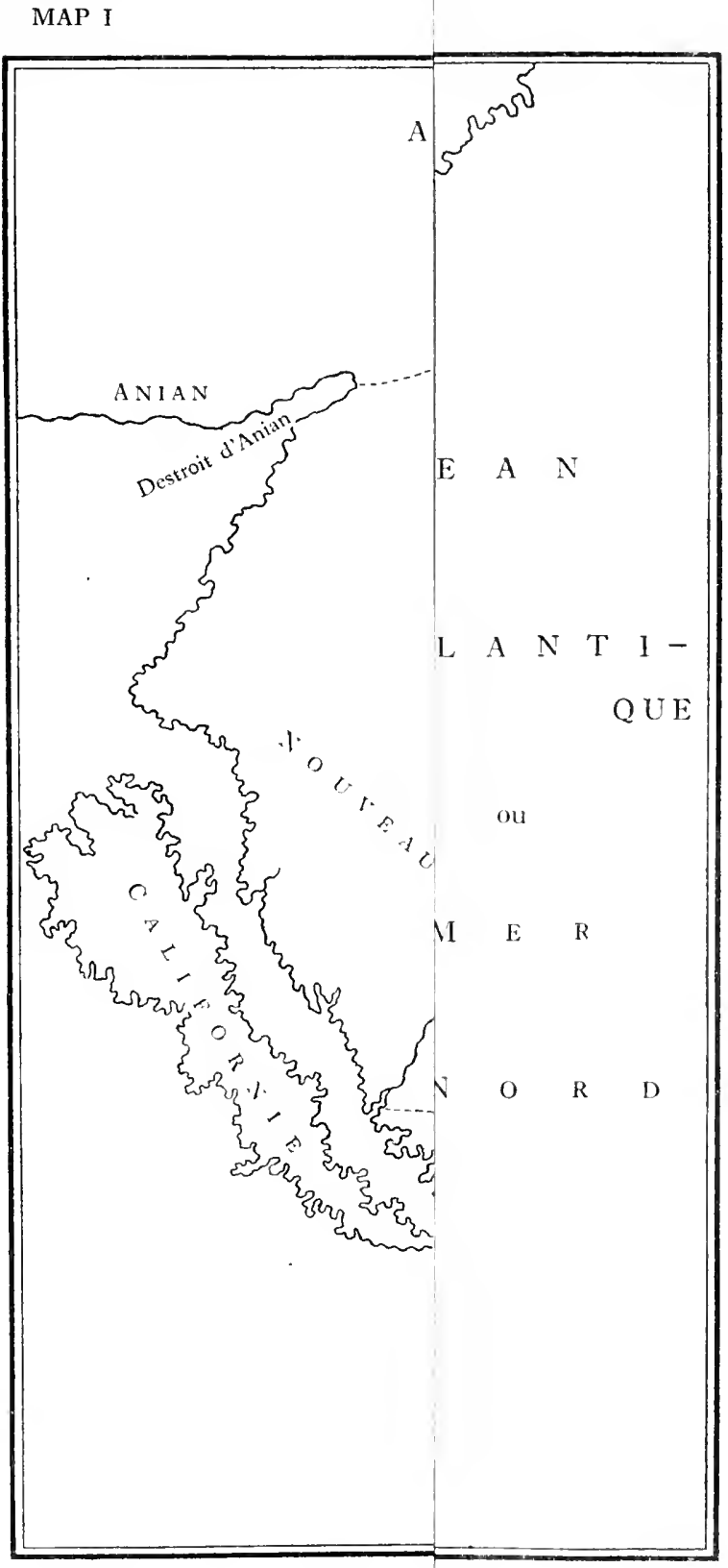




\section{CHAPTER I}

\section{INTRODUCTORY}

\section{Early colonial policy}

In the early years of English colonization, the home government shewed neither a definite nor a consistent policy. 'The early Stuarts were the witnesses of a new movement, the development of which they could not clearly foresee; and their attitude was therefore hesitating and tentative. The remarkable tale of exploration and adventure which distinguished the Elizabethan age came to an end; and the interest of Englishmen in the New World took a fresh direction. The merchants who first visited America in search of the precious metals now began to see great possibilities in a more solid though less spectacular commerce; and sought to plant trading settlements. For this purpose they made application to the King for charters of privilege. James I attempted at first to confine the Virginia Company to the purely commercial activities of the new settlement there, but soon found it necessary to give wider powers of government to the company; and the charter subsequently given to the Governor and Company of Massachusetts Bay was of such a kind as to enable the entire government of that settlement to be carried on in the colony itself. The fertility of the soil speedily ensured the stability of the newly-established. colonies, provided that the first difficulties of organization could be overcome; and the development of Virginia and the similar plantations in the West Indian islands, depending chiefly upon the production of tobacco and sugar, was rapid. Moreover, about the same time, religious dissension at home induced Puritans, and later, Roman Catholics, to take advantage of the new openings and to establish societies where their religious opinions would at least not be penalized. By this means settlements spread over considerable areas in New England and Maryland. The latter colony was also the type of the alternative method of government used by the Stuarts-that of the proprietorship. Lord Baltimore was given 
powers of government within the settlement, with powers to make laws there; and as the century advanced the number of proprietary and charter governments increased, until the trend of colonial policy turned again to more intimate royal controla development which had been suggested in 1623 by the abrogation of the Virginia Company's charter, and the transference of political government to a governor and council appointed by the King ${ }^{1}$.

The beginning of the colonizing movement led naturally to the expression of ideas on the problems emerging therefrom, and more generally on the whole question of colonization. At first there was a tendency to welcome the new settlements as a dumping ground for the surplus population of the home country. There is much testimony to the bad character of many of those sent out to the colonies, although it is doubtful if, prior to 1650 , convicts were transported thither without special mitigating circumstances ${ }^{2}$; and many of those considered unfit for the full extent of citizenship in England-religious dissidents, political prisoners-were by their very disqualifications rendered especially suitable to the pioneer work of colonization. Apart, too, from this aspect of the new settlements as a means of disposing of political and criminal offenders, there was a widespread opinion in England that the prevalence of poverty and its attendant evils could be checked by sending away part of the surplus population from which those evils were believed to derive. As the century progressed, however, this view was greatly modified ${ }^{3}$. In view of this popular opinion of the merits of colonization, it is not surprising that those who left the old world for the new should definitely express their wish to be independent of the country which had thus driven them to emigration; and in practice this independence was very great under James I and Charles I. Massachusetts could say in 1646 :

1 Charles I's royal proclamation of 1625 had expressed the resolution to have 'one and uniform course of government in and through all our whole monarchy.' But little had been done to justify the resolution. (Egerton, Hist. of Brit. Col. Pol., p. 44.)

2 See Egerton, op. cit. p. 40.

3 Beer, Origins of Brit. Col. System, Chap. II, and Old Colonial System, Chap. I. 
We have absolute power of government...to correct, punish, pardon, govern and rule the people absolutely...The laws of the Parliament of England reach no further, nor do the king's writs under the Great Seal go further

[i.e. than while they lived in England]. Barbados in 1651 protested against being 'subjected to the will and command of those who stay at home ${ }^{1}$.'

The supremacy of the parliament in the Civil War resulted in definite claims over the reluctant colonies. A charter was granted to Rhode Island, formed by separation from, and against the wishes of, Massachusetts ; and other instances appear of assertion of rights by the home government, accepted unwillingly by the colonies. Cromwell's accession to power carried on this policy. Cromwell himself, the first great Englishman to think imperially, actually suggested the settlement of Ireland from New England, as a means of diminishing a now formidable tendency to separation, whilst shortly before, the government had approved a suggestion from Colonel Modyford to solve the problem as far as Barbados was concerned, by representation in the English parliament. Cromwell's period of rule was however too short for a reorganization of the colonial system. The capture from Spain of Jamaica in $1655-9$, then a barren and ill-populated island, was destined to rank as an important colonial development, but it was not highly prized at the time. By now trading interests had become paramount and the logical result was the Dutch war, foreseen by Thomas Mun as early as $1628^{2}$. The same interests induced Cromwell to encourage the deportation of vagrants; and instructions were issued for the Major-Generals to arrange for transportation of undesirables with merchants trading to the colonies.

\section{The Navigation Laws}

In $165 \mathrm{I}$ appeared an ordinance which represents the beginning of the series of restrictive statutes concerning English and colonial trade - the beginning, that is, of those Navigation Laws which were at the same time important and destined to be enforced. (Previous measures of like nature had failed in at least

1 See Egerton, op. cit., p. 58.

2 England's Treasure by Foreign Trade, I895 edn., p. III. 
one of these respects.) The Act of $1_{5} 6_{5}$ was aimed at Dutch shipping, and forbade exportation to, or importation from the colonies of any goods, except in English ${ }^{1}$ or plantation-built ships. The development of the principle of Navigation Laws under the Restoration government started from this ordinance, and carried the system far beyond what was there intended. The Act of 1660 provided for preference to be given to English or Irish shipping in importation from Europe, and for a complete monopoly of the coasting trade. In both these cases, colonial ships were included as English. Trade with other parts, outside Europe; was confined to English (including colonial) or Irish ships, and these were compelled to use the place of production or the usual port for that trade. (A later exception was made in the case of Spanish and Portuguese colonial produce, which could be shipped direct from those colonies.) Finally, English trade with the English colonies had to be in English, Irish or colonial ships. As an afterthought to this series, a clause was added providing that no sugar, tobacco, cotton wool, indigo, ginger, or dyeing woods produced in the English colonies could be shipped elsewhere than to England, Ireland or some other English colony ; and to enforce this clause, bonds were ordered to be taken from ships in England and in the colonies, to be forfeited if they took the goods elsewhere than where this act allowed. Further, by the Staple Act of 1663 , no European goods with certain exceptions ${ }^{2}$, could be imported direct to the colonies, but must be landed in, and re-exported from England. In 1673 export duties were imposed on goods of the enumerated class as above, on being shipped from one colony to another, complaints having arisen that by first taking the goods to another colony the restriction on shipping direct to Europe was evaded. The duty was in practice alternative to the forcing of bond. If bond was not given to take the goods to England only, the duty was to be levied, in the hopes that thereby illegal trade would be made unprofitable. It is worthy

1 The term 'English' meant English-built, with a master and threequarters of the crew English subjects.

"Such as salt for the Newfoundland, etc., fisheries, horses and provisions from Scotland and Ireland, and wine from the Madeiras and the Azores, with doubtful inclusion of that from the Canaries. 
of note also that, probably by technical oversight, the bonds taken from English merchants trading to the colonies bound them to bring back the goods obtained there to England only; whilst the colonial bonds required the merchants to take their goods to England or any other colony (with the qualifications mentioned above in the payment of duty). When this rule was enforced, at the end of the Restoration period, colonial merchants were thus given a monopoly of the inter-colonial trade. By this series of statutes, Scotland was excluded from participation in English colonial trade, although the royal dispensing power availed at times to the contrary; but individual Scotchmen had the right of settling in the colonies and trading there as English subjects, according to popular opinion, although controversy on this point prevailed throughout the century ${ }^{1}$. The justification for the restrictions on colonial trade was mainly on the ground that England bore the burden of Imperial defence. In so far as this statement often implied or definitely included the whole of that burden, there was to be some ground for modification in the period following the Revolution. A secondary compensation was found in the privileges given to colonial products in the home market. Enumerated commodities were rated much lower in the tariff of import duties than similar foreign products; and cultivation of tobacco, the only one of those commodities which could be successfully grown in England, was prohibited there, the colonial monopoly being enforced with great effort, in face of considerable difficulty ${ }^{2}$.

\section{The old colonial system}

On this framework the colonial policy of the Restoration was built up. The period following the accession of Charles II was one of vitality and expansion in many directions. Charles himself took especial interest in trade and the plantations, and his example was followed by Clarendon, Arlington and other less known but careful students of policy. As a result of this renewed interest in colonization, certain precepts of the age emerged, giving a clue to much of the colonial history at that time. In

1 See Beer, Old Colonial System, I, p. 88 et seq.

2 Beer, $I b$. especially Chap. III. 
the first place, the idea of an over-populated England was disappearing, and instead, the doctrine that men were the wealth of a nation was coming to the fore. Thus it was objected that the colonies drained England of her true wealth, and should not be encouraged. The answer usually given was that the labour of the emigrants was of greater value to the home country after their settlement in the New World than it was at home, the example often given being that of the West Indian planter who employed perhaps twenty negroes to the one white man of whose labour England was deprived. Additional value was also obtained from the profit of plantation-grown commodities, either of different or of superior quality to those produced at home $^{1}$, and from the colonies' function as market for home production. From this precept, two more were readily deduced. If labour was needed in the colonies, and yet should not be spared from England, the obvious source was from the criminal classes, and from other undesirables of similar or higher category. Thus, religious dissidents, such as Quakers, were sent from prison to the colonies; Irish rebels were sent over to Barbados in 1666 , and many of the rebels of 1685 found labour in Barbados and Jamaica ${ }^{2}$. Ordinary malefactors were often 'ordered' by the colonies which needed labour. Secondly, if the justification for genuine emigration rested on the employment of negro labour or on the cultivation of goods for which high prices could be obtained in Europe, then it followed that encouragement should be given only to those colonies in which these conditions were fulfilled. Hence followed the disapproval of the New England colonies, which was a marked feature of the Restoration period. This disapproval may be further understood when statistics revealed the proportion of trade between England and the Northern colonies-New England, New York and Pennsylvania - as a little more than one-tenth of the whole trade with American and West Indian Colonies ${ }^{3}$. A further justification for colonial activity was in the training of seamen and the employment of shipping. But here again the North failed, owing

1 See Penn, Benefit of Plantations (1029 E ${ }_{5}$ in British Museum Catalogue).

2 See below, pp. $165^{-6}$.

${ }^{3}$ Beer, Old Colonial System, Chap. I, p. 42. 
to its relatively small trade, whilst its fisheries rivalled those of Newfoundland, the settlement of which was purposely discouraged in order that the fisheries might attract more shipping by the absence of a fixed colony as base.

Allusion has been made to the question of imperial defence. At various times in the reign of Charles II, land forces were stationed at Barbados, Jamaica and St Kitts, to protect this nest of profitable plantations from sudden onslaught, in New York, for fear of French invasion, and in Virginia, because of Indian inroads; but at the end of the reign these garrisons had decreased, mainly through difficulties of pay, to a small force at the English part of St Kitts, and two companies of infantry at New York. The English government had also in certain cases, notably that of Jamaica, spent money on fortifications in the colonies.

A typical feature of the Restoration colonial policy-due to the combination of revived interest with a plenitude of deserving and undeserving courtiers whom the restored monarch delighted to honour - was the system by which large areas of land in the colonies were granted as proprietaries to private individuals. New Amsterdam, conquered from the Dutch in I664, was handed over to James, then Duke of York, who immediately transferred the part between the rivers Hudson and Delaware to two faithful friends, Berkeley and Carteret, to found New Jersey. A similar arrangement provided for the settlement of Carolina under eight noble proprietors, and also for that of the Bahama Islands; whilst the grant of Pennsylvania to its Quaker founder formed part of a settlement of financial affairs between Penn and the King. In all these proprietary settlements advancement of trade became the criterion of government.

\section{The movement for independence}

Towards the close of Charles II's reign, affairs in New England developed in such a way as to demand interference from home. Ever since the Restoration, Massachusetts had attempted to avoid definite recognition of its colonial status, and had worked against the principle embodied in the Navigation System, both by executive and legislative action. Trusting 
to the reluctance of Charles to take drastic action, the colony had refused to send agents when required, had made laws contrary to its charter, and was proved to have indulged considerably in illegal trade. Under these circumstances the home government was constrained to take up a strong attitude. After hearing the evidence of several responsible witnesses, proceedings were instituted against the charter, which was annulled in $1684^{1}$. Before fresh arrangements could be made for the government of Massachusetts, the King died. His attitude to the colonies had shewn some realization of their importance, and of the impossibility of a complete laissez-faire policy; and not the least of his achievements was the selection of governors who were something more than mere placemen.

\section{The colonies under fames II}

At the accession of James II, the outline of the North American colonies had begun to take the form which with some modifications is familiar up to the War of Independence. In the North were the colonies whose chief trade was in provisions (to the other settlements), furs and skins obtained from the Indians, and naval stores of timber, pitch and the like, in small quantities. These colonies competed with the mother country not only in the provision trade but also in their fisheries, which rivalled those of Newfoundland. Massachusetts, as has been stated above, was now waiting for the reorganization of its government after the abrogation of an exceptionally independent charter. Rhode Island and Connecticut had both received charters, whose fate was likely to be the same as that of the older one. New Plymouth had declined relatively in importance since the day of its famous founders and was not likely long to survive any attempt at increase of the royal power. New Hampshire and Maine were in an unsettled state, owing chiefly to large, vague and disputed grants of proprietorship to private individuals, grants further complicated by sale and bequest of rights. New York was still in its infancy, but gave promise of its future position; whilst by the accession of its proprietor to

1 Beer, Old Colonial System, gives a detailed account of the proceedings in Vol. II, Chap. XI. 
the English throne it became a royal colony. The French menace however was speedily forcing New York into prominence, the more since in Dongan and Andros, its governors, English rights were stubbornly and ably upheld. New Jersey, like New York an agricultural colony, was in proprietary hands, and, divided into Eastern and Western portions, had a complicated constitutional history until the end of the century. Next to these came the newly-founded settlement of Pennsylvania, which under the peaceful Quaker merchants was beginning that course of commercial prosperity, which, combined with the pacific tendencies of the inhabitants, was destined speedily to arouse the jealousy of neighbouring states. Then came the more favoured of the colonies, Maryland, under the proprietorship of Lord Baltimore, and Virginia, the oldest royal colony, both of which depended for their prosperity on the tobacco plantations, although efforts were being made to develop other nonEnglish products. Last of the mainland settlements came the Carolinas, proprietary colonies, as yet in a turbulent and uncertain condition.

\section{The West Indies}

In the West Indies, Barbados enjoyed a long-established importance by virtue of its sugar trade. Proprietary government had been abolished by the crown in return for an annual export duty of $4 \frac{1}{2}$ per cent., and henceforward the island was concerned mainly with the price of sugar and with this duty, and with some minor productivities of which cotton growing was the principal. The Leeward Islands, of which Antigua, Nevis, Montserrat and (half) St Kitts were the important islands, formed a separate government, and sugar, ginger and tobacco were its main products. 'From Jamaica much was expected, but as yet the settlers had been too much diverted by more exciting pursuits among the neighbouring coasts to make much progress towards the fulfilment of these commercial hopes. Already a struggle had begun about the grant of a permanent revenue to the crown ${ }^{1}$. The Bermudas, whose small islands

1 See Transactions of $R$. Historical Society, 4th Series, Vol. I. Egerton, System of Brit. Col. Administration of Crown Colonies in I7th and I8th Centuries. Also below, pp. 138-9. 
had but limited capabilities, were prosperous in a small way, in spite of a prolonged fight with the privileged Bermuda Company, which had finally resulted in the establishment of royal government in 1684 . The peculiarly important strategic position of these islands gave them a greater importance than they could have ensured by their commercial possibilities alone. Finally, the proprietary group of the Bahamas made up the sum of British colonies in the New World. These islands were chiefly notorious as the resort of pirates and disorderly persons, and could hardly be dignified with the title of a responsible government. In all the colonies, of mainland and islands alike, the Navigation Acts were the matter of primary concern, and illegal trade was carried on to a great or small extent according as the colony in question was or was not remote and under indirect control from England.

\section{Colonial administration}

The home government of the colonies was at this time carried on by a committee, composed of many of the chief state officials, together with the Committee of the Privy Council for Trade and Plantations, the whole body being known usually as the Lords of Trade. This committee had come into existence after many experiments with committees of the Privy Council, and with separate boards for Trade and for Plantations, or for both together; and, chiefly by virtue of the importance of its chief members, able to give the force of law to the greater part of its recommendations. In addition to this main authority, the Admiralty had jurisdiction over those branches of the colonial system concerned with prize-ships, and later with illegal traders, and had courts in the crown colonies to carry out this jurisdiction, on similar lines to the Vice-Admiralty courts in England. Another important source of authority concerning the Navigation System was the Treasury, which was concerned with the duties and bonds which formed a vital part of that system. To enforce the Laws of Trade in the colonies themselves, the governor usually appointed a 'clerk of the naval office,' known as the 'naval officer'; whilst the Commissioners of Customs had their own collectors in each colony, supervised by the 
Surveyor-General of Customs. (This latter office was now held by Edward Randolph, whose determination to enforce the letter of the law in face of all opposition had already brought him into disfavour in the colonies; and whose conduct typified, as did that of no other single man, the spirit of the Navigation System ${ }^{1}$.) Local government in the colonies varied with the source of authority. In all cases there was a governor, appointed either by the crown, by the proprietors, or under the provisions of the charter in charter colonies. He governed with the assistance of a council, generally similarly appointed in whole or part; and the popular share in government was confined to an assembly which met under different names in most of the colonies, its power varying with the control over revenue which circumstances enabled it to exercise. In most cases it had final authority in deciding what money should be spent on domestic affairs.

\section{The movement towards union}

The colonial administration of James II was chiefly notable for the first serious attempt at union of the colonies, and at centralization of colonial government. At one time or another during his short reign, the King instituted proceedings against all the private charters, and it was mainly a matter of chance which survived the fall of James. The first to go were the New England charters. In 1686 Sir Edmund Andros was sent to Boston as Governor-General of New England, with authority including Massachusetts, Plymouth, Rhode Island, New Hampshire and Maine. He was instructed to enact laws 'by governor and council,' thus depriving the province of popularly elected assemblies. A further step was taken in I 688 when New York and the Jerseys were added to his governorship, and a special flag designed to symbolize the newly-attained unity. Before James could do more, the revolution overtook him, and deprived posterity of the results of an important administrative experiment. It is worth remembering that (in the words of Mr Fortescue) "under the superintendence of so capable an administrator as King James, colonial business was handled at

I For Randolph's life and documents connected with his office, see R. N. Toppan, Edward Randolph, 7 vols. 
Whitehall with an energy and swiftness hitherto unknown ${ }^{1}$." And yet it was a period of ceaseless anxiety and trouble.

\section{The French menace}

For while constitutional experiments were engaging the King's attention, Dongan, his faithful deputy in New York until superseded by the new government of Andros, was concerned with equally momentous issues. The story of his relations with Denonville, the urbane governor of French Canada, has become well-known in the classic history of New France ${ }^{2}$. Suffice it to say that in James II's reign Anglo-French relations in Canada were becoming definitely hostile. From the discoveries of Champlain to the explorations of $\mathrm{La}$ Salle, some seventy years, French settlements in Canada had steadily increased whilst the indomitable Frontenac, their governor, gave an added vitality to the French cause. The two systems of colonization, English and French, had grown side by side until by now the Iroquois tribes were the only buffer between the rival outposts of Corlaer and Onontio ${ }^{3}$. Consequently, the governorships of Dongan and Andros in New York were always concerned with the French menace. Both sides, French Jesuits and English merchants, were working for influence with the Five Nations of the Iroquois, and the reign of James was a state of half-war. Most of the Indian tribes of the Five Nations accepted an English alliance, if not a vague suzerainty, but the French were always active to undermine this alliance, not without much success at times. It is quite evident that behind all the protestations and proposals for neutrality in the event of war elsewhere, the two nations were being driven to war by conflicting interests. The climax came when the same year, I689, which marked the accession of William of Orange to the English throne, saw also the return to Canada of Count Frontenac. The issue was a great one, for it the independent spirit of the New England colonies should prevail, the entire future of English colonial possessions might turn on the result of that war.

1 C.C. $1685-8$, Preface.

${ }^{2}$ Francis Parkman, Count Frontenac and New France under Louis XIV, Chaps. VI-IX.

3 'Corlaer' was the official Iroquois name for the governor of New York; 'Onontio' the governor of Canada. 


\section{CHAPTER II}

\section{THE REVOLUTION OF I689 IN THE COLONIES}

The Revolution in England was used in America to arouse revolt against centralized government, union, and a close English connection; but it also introduced the war with France, in Europe and in America.

\section{(a) The Revolution in New England}

The addition of New York and the Jerseys to Andros's already large province of New England marked the beginning of an anxious year for the governor. The disputes with France were increasing in intensity; and it invariably happened that disputes with France meant attack by Indians. Andros did his best to cope with the situation, and appeared to have gained the mastery when the revolution came upon him; but it may well be that, under the special urgency of the situation, his hand was laid more heavily than usual on the sensitive people of Massachusetts, still smarting from the blows which Charles and James had inflicted on their dignity and independence. The partisan statements of the revolutionaries certainly give this impression; and at any rate there can be no doubt that Andros was extremely unpopular with the 'independent' party of Massachusetts.

\section{The outbreak in Boston}

In November 1688 , popular disaffection in England resulted in the landing of William of Orange, with a proclamation promising redress for public grievances. By the following January, the flight of the King left William in power; and he issued a provisional order to the colonies, continuing all officers for the present in their several offices ${ }^{1}$. Finally on February $19^{\text {th }}$ the Council issued orders to colonial governors for the proclamation of William and Mary as joint sovereigns, the continuation of officers, and the administration of the usual oaths of allegiance ${ }^{2}$. Early in January, if not before, Boston had received official warning of a prospective Dutch invasion; and Andros

$$
{ }^{1} \text { C.C. } 1689-92,8 .
$$

${ }^{2} \mathrm{Ib} .20-\mathrm{I} i$ 


\section{I4 REVOLUTION OF I689 IN THE COLONIES [}

had taken necessary precautions, as in duty bound. In April, the first of William's declarations was brought to the governor from the West Indies, and on the 18th of that month an insurrection broke out in Boston. Rumours of revolt appear to have been circulated in various quarters of the town, with the result that early in the day large companies of insurgents came together. Their first step was to secure Captain George of H.M.S. Rose, then lying in the harbour. Andros's officers were next seized, among them Edward Randolph, at this time secretary to the Dominion. At this stage a council was called together, and Simon Bradstreet, the last governor under the old charter, drew up a paper of reasons for revolt. Meanwhile Andros, hearing of the disturbance, went down from the fort to the town house, where the council of war had assembled, and demanded the meaning of the disturbance. He was promptly seized, and confined in a private house, whence he was later removed to the fort. The insurgents now persuaded Randolph-according to one account, with a pistol at his head-to advise the surrender of the fort, and the following day the castle also fell into their hands. The call to surrender was signed by Bradstreet, Danforth, the late deputy-governor under the charter, and others, who, in response, as they claimed, to a universal desire, assumed the government until further directions should be received from England ${ }^{1}$. Randolph and Joseph Dudley, the President of Massachusetts appointed after the abrogation of the charter, were thrown into the common gaol, where the former spent much time in penning long and indignant letters to the home government; the judges, the attorney-general, and several of the officers were imprisoned in the castle, and Andros was kept in close confinement. He succeeded at one time in eluding his guards, but was recaptured and brought back ignominiously in the woman's clothing that he had imperfectly assumed for disguise. Thus they remained until the King's order in July for their release and despatch to England reached the acting authorities. According to Bradstreet the revolution had been

1 Bradstreet to the King, C.C. $1689-92$, No. 138 . But Randolph (ib. 1 52) speaks of their 'much time in consulting what model of government to erect.' 
accomplished without either bloodshed or plundering. The council thus constituted communicated with the home government as if assured of public approbation, asking a favourable interpretation of the measures which they had been obliged to use, in order to establish their authority, and begging restoration to 'undoubted rights.' ${ }^{2}$ Such was the revolution in Massachusetts, leading to the establishment of a de facto government, based on the old charter, until a commission was given to Sir William Phips as governor in November 1691 , in accordance with the new charter of that year.

\section{Reasons for the revolt}

There is little doubt that the mere news of King James's deposition and the accession of William III was not enough to provoke such an outburst of feeling in Boston, unless there were strong currents of opinion beneath the surface. It is moreover very questionable if the popular distrust of Andros took the shape of fear that he would attempt to resist the establishment of the new régime, when authoritatively informed of the charge. It was to be but a few years later before Andros was again a governor on the American mainland; and though it must be admitted that his character was not always clearly understood, that his staunch Protestantism was by some mistaken for Popery, yet the hatred he aroused appears invariably to be caused by the state of things he had already brought to pass at the time of the revolt against him, not by fears that he would stand out for James in the teeth of English opposition. Moreover, the rapidity with which the revolt in America followed the news of William's success in England may be taken to indicate a constant readiness to seize any likely opportunity of overturning the existing government.

\section{The manifesto of 1689}

The first statement of reasons for the outbreak in Boston is to be found in the manifesto issued by the rebels in $1689^{2}$. This document begins by citing the Popish plot of 1678 as an example of the danger to be feared under a monarch with Roman Catholic

${ }^{1}$ Bradstreet, for the Council and Convention, to the King, C.C. I689-92, 182.

${ }^{2}$ Narrative of the Proceedings at Boston, $I b .261$. 
inclinations. The second head is more definite. 'The charter, it reads, has been vacated with hardly a pretence of law, 'hastened by the unwearied solicitations and slanderous accusations of a $\operatorname{Man}^{1}$ for his malice and falsehood well known to us all,...to get us into reach of the desolation desired for us.' 'The other grievances follow on this. Andros has been sent with a more arbitrary commission, and moreover with several companies of redcoats to enforce it. He has used this authority to heap preferment on strangers; whilst persons who objected to be rated without an assembly have been heavily fined or imprisoned without verdict of jury or right of habeas corpus. Swearing has been made compulsory for jurors. Flaws have been found in titles to land; and these iniquities have been perpetrated not even by the whole council, but by the governor and five or six councillors. In addition there has been the burden of Indian raids, defence duties and the irksomeness of Popish commanders appointed over them by Andros. Finally they adduce the example of William, which has led them to take strong measures against the tyranny they abhor.

Now this manifesto can hardly be taken at its face value. The charges of illegal proceedings can for the present be ignored; as, if founded on fact, they will appear in the case against Andros before the Lords of Trade in the following year. 'The remaining charges reflect the jealous spirit of independence characteristic of the Puritan colonies. Their theocratic system has been offended by forms of worship alien to their own religion and these they are swift to denounce as Popery. The practice of swearing in judicial proceedings has similarly offended their beliefs. But the heart of the matter is in those clauses which relate to the charter and the method of government. Their exclusive independence has been taken away-they assume, illegally-and a hated system of centralized control substituted for it. Preferment has been given to strangers-again their own influence weakened. They even go so far as to object to fines imposed on those who refuse obedience to the tyranny-a curiously illogical frame of mind, assuming that even the force

1 Obviously a reference to Edward Randolph (see Toppan, Edward Randolph, for details). 
which has oppressed and overcome them should admit that it is in the wrong and refuse to press its claims. Flaws found in titles to land, the governor acting without the entire councilsuch finally make up the sum of causes which bring the people of Boston to a grave sense of insecurity. Unless they act quickly their independence will utterly fall. The deposition of James II is a Heaven-sent opportunity; but they must shoulder their own burden. They dare not trust William. It is the extension of English rule which they fight against, not merely the policy of a Stuart king. This is the spirit of the 1689 manifesto, standing out clearly, irrespective of the truth or falsehood of the detailed charges:

\section{The convention of $\mathrm{r} 689$}

The convention called shortly after the outbreak of revolt shews the same spirit. Its members, reads the declaration ${ }^{1}$, are resolved to venture their lives and estates for the reviving and maintaining of their rights and privileges, and for government according to their ancient patent. Apart from these aims, there appear some insinuations against Andros which played a considerable part in kindling the flame. Captain George of H.M.S. Rose tells us $^{2}$ that it was popularly rumoured that Andros intended to deliver the government to the French, to burn the town (a singularly common charge against any unpopular governor) and to have the Rose beat down the mob at the other end of the town with her guns and then make for France. Another writer ${ }^{3}$ asserts that Andros kindled the Indian war to coerce New England, and that the Rose. was intended to take him also to France.

\section{The case against Andros}

A further source of information about the feelings of Massachusetts is the case brought against Andros and his subordinates before the Lords of Trade ${ }^{4}$. The first charge put forward by the agents for the colony was that Andros, after notice of William's intention to invade England, required persons to

1 Narrative of the Proceedings at Boston, C.C. $1689-92,26 \mathrm{r}$.

2 The Captain-General to the Secretary of the Admiralty, ib. I96.

3 An account of the late Revolutions in New England, $i b$. I80.

4 Matters objected against Governor Andros, $i b .828$. 
oppose such a Dutch invasion, tried to stifle news of his landing, and imprisoned the messenger as seditious. The answer to the first charge was obvious. The governor had obeyed James's orders to resist a foreign attack, as was his duty. The other charges he denied as untrue ${ }^{1}$. The remaining offences urged against him were the making of laws and the imposition of taxes without legal authority, denial of the people's right to property in land without his patent, and the supply of ammunition, with other encouragement, to the Indians. Andros replied that all his laws were legal, and moreover that the taxes in question amounted to but $\mathrm{I} d$. in the $£$, whilst the revolutionary government imposed seven times as much. The other charges he characterized as vile and base aspersions, unworthy of Englishmen and Christians. No attempt was made to prove the charges.

\section{Randolph's reasons}

Meanwhile Edward Randolph, the inveterate champion of the home government, had set forth the reasons to which he attributed the movement against Andros ${ }^{2}$. He centres all round the Navigation System. Since their charter was vacated, he says, the people of Massachusetts have been kept from breaches of the Navigation Acts, and from fitting out privateers to the Spanish West Indies, in which offences their agent in London was a great offender. They have also been kept from trade with the French in Newfoundland; liberty of coinage has been denied them, in order to discourage pirates; whilst their ministers who have absolute control of the people, are the leaders in such misdeeds. Already, Randolph continues, seven pirates have been liberated and permitted to sell their goods; and privateers are even now fitting for the West Indies. It is dangerous to trust absolutely such testimony as this, in view of the bitter hostility which had long existed between Randolph and the local authorities of New England; but in view of the extent to which the laws of trade had been evaded there before $1684^{3}$, it

1 C.C. $1689-92,844$. This denial includes the imprisonment of the messenger, which is stated as a fact by Professor Channing, Hist. of United States, II, p. 199 and by Mr Doyle (Cambridge Mod. History, vir, p. 30).

2 Edward Randolph to the Committee of Trade Plantations, $i b$. I 52.

$s$ Beer, Old Colonial System, Vol. II, Chap. XI. 
is hard to dismiss his charges completely; the more since he spares no pains to give minute details in substantiation of his main arguments.

\section{The revolutionary party's conduct}

The acts of the successful party during their period of rule should also give some clue to the reasons which inspired the revolt. According to Randolph ${ }^{1}$, the height of revolution produced a furious rabble, animated by the ministers, who proceeded to cry down customs, excise and Acts of Navigationthe symbols of English rule. 'One of their ministers lately declared in public that they accounted themselves the King's nominal, not real, subjects.' And a pamphleteer of the same time $^{2}$ complains that the laws of England were unknown till Andros's time. These statements, made evidently in the heat of revolt, may be taken as the extreme of a tendency which did not carry all so far along its course.

Whilst English laws were thus opposed, the English Church did not escape its share of persecution. In January, I690, the members of the Anglican communion in Boston drew up a petition ${ }^{3}$ setting forth their grievances. It appears that since the overthrow of Andros frequent indignities had been their portion. Their leaders were accused of idolatry and Popery; their church was damaged and daily threatened with destructions; their ministers had been 'destroyed,' and the whole community excessively taxed for the support of a disloyal government. One of their ministers bears out this statement ${ }^{4}$, adding that the Church was perpetually abused, and its members much threatened with their fate 'when the charter comes.' The revival of charter government did not promise well for the Anglican Church in New England, for in practice their only freedom of worship had been during the few years since the much vaunted charter was vacated; whilst Cotton Mather,

1 Randolph to the Committee of Trade Plantations, C.C. I689-92, 285.

2 'The Case of Massachusetts Considered' in a letter to a friend at Boston, ib. 133 .

3 Address of members of the Church of England to the King, ib. 742.

4 Letter of Samuel Myles, $i b$. 1217. 
whose 'dynasty' long held sway in the Puritan theocracy of Boston, attributed the ill fortune of the new government to the little English chapel, which they had permitted to stand ${ }^{\mathbf{1}}$.

\section{Defence neglected}

The conduct for which the acting authorities cannot however be excused was in relation to the defences of New England. The revolution came at a time when French and Indian attacks were constantly threatened. Less than a year before had come Indian raids on Northfield and Springfield ${ }^{2}$, which should have been still fresh in memory. And yet the council displayed a reckless disregard for the country's safety which can only be accounted for by complete absorption in the struggle with English control. Instructions were sent for the dismissal of the regular officers in the Eastern garrisons, and these were to be sent back to Boston. At Pemaquid, the outpost against the Indians, the senior officers were replaced with the result that the majority of the garrison deserted, and the people of Pemaquid in fear insisted on keeping one of their junior officers as unofficial adviser to the new control. The disastrous result of this policy followed within a few months. The usual instructions issued appear to have ordered the reservation of as many men as were necessary, and the dismissal of the rest-an order which was interpreted with little eye to the frontier danger. An equally short-sighted policy encouraged the dismantling of the Rose, the royal frigate in Boston harbour. At the outbreak the carpenter had been chief instigator against Capt. George, and according to the latter's testimony ${ }^{3}$ the sails were removed, and all who would not take the carpenter's side were put ashore. In addition, many men deserted, with the result that Boston had no protection at all for her coast; and, according to Randolph, six Salem ketches were taken by the French off Cape Sable, while the Rose was thus out of action ${ }^{4}$; whilst other inhabitants of Boston claimed that $f_{12,000}$ worth of damage had been done

1 Letter of Samuel Myles, C.C. I689-92, 1239.

2 C.C. $1685^{-8}, 1877$. The raids were in Aug. 1688.

3 Capt. George to the Secretary of the Admiralty, C.C. $1689-92$, 196.

- Randolph to the Committee of Trade, $i b .482$. 
by pirates, from the same cause ${ }^{1}$. Not till the condition of affairs was realized in England and orders issued from home for repairs to the frigate ${ }^{2}$, was this dangerous situation remedied.

\section{Revolutionary government}

The provisional government was not long in power before general complaints were voiced against the disorder of the country. Long catalogues of misrule came, of course, from Randolph, who stated that vessels came in freely with goods contrary to the Navigation Laws or from prohibited countries, without any disturbance being made on that account; whilst if customs officers attempted to carry out their duty, they stood good chance of being knocked on the head ${ }^{3}$. Here, as before, it is only fair to Randolph to point out that he is precise in his instances, and challenges the government to produce bonds they have taken of sea-going ships, that his accusations may be refuted ${ }^{4}$. Others besides Randolph find much to lament in the new government. 'The injuries and oppressions they have loaded us withal' is the theme of one pamphleteer ${ }^{5}$. Certain gentlemen and merchants of Boston complain that New England is 'in very broken and unsteady fortune.' Charlestown (Mass.) complains of the disorder and confusion, and appeals for the 'protection and benefit of the laws of England 6 .' Moreover, the government itself had many hindrances in carrying out its executive functions. The people were not satisfied that they had the power to raise either men or money. Great difficulty was found in collecting rates; and debentures on the collectors were at 25 per cent. to 50 per cent. discount ${ }^{7}$. The revenue became so inadequate that in December 1689 the general court ordered the collection of arrears of rate since $1686^{8}$. The raising of forces for defence was as difficult. The press came out; but 'some questioned the pay, some their authority, and few or none

1 Members of the Church of England to the King, C.C. I689-92, 742.

2 Bradstreet to the Earl of Shrewsbury, $i b$. 745 .

3 Randolph to the Commissioners of Customs, $i b .468$.

4 Randolph to the Lords of Trade, $i b .482,949$.

5 A Friend in the Country to a Bostoner, ib. 135 .

6 Sundry Inhabitants of Charlestown to the King, ib. 743.

7 Journal of Benj. Bullivant, $i b .885$.

8 Orders of the General Court of Massachusetts Bay, $i b .76 \mathrm{r}$. 
went ${ }^{1}$ ' When expeditions were being organized under Sir William Phips for attack on the French settlements, Phips's men mustered without arms; and on being told to find their own, eighty of their number deserted. 'Some few enlist, and then change their minds and desert, and none dares question them ${ }^{2}$.' When it was desired to send help to the defence of the Maine townships, there were no officers found fit for such service; whilst when the men were found, the neglect to look after their needs was conspicuous. After the return of the expedition against Quebec in 1690 complaints of neglect and want were rife. 'Men died in holes before they were missed.... Those who arrived at Boston die up and down like rotten sheep ${ }^{3}$.' The expenses of Indian wars since the revolution had to be paid by private gentlemen, in default of public funds 4 . The soldiers, dismissed or deserting, returned from the eastern garrisons, and rioted about Boston with the comprehensive cry on their lips: 'God bless King William; God bless Andros; and damn all pumpkin states ${ }^{5}$.'

\section{The charter}

As has already been indicated, it was the charter which formed the background of the revolution. The new government was established on 'the desire that the Governor, Deputy Governor and Assistants of 1686 should assume the government ${ }^{6}$ ' Once established, the petition of the newly constituted authorities was for 'a share in the universal restoration of charters of English liberties?' It was the deprivation of the charter that caused the people to imitate the English example ${ }^{8}$; and that charter, illegally taken, could be resumed ${ }^{9}$. A merchant, writing from New England ${ }^{10}$, described the greater part of Massachusetts, New Plymouth and Connecticut as calling itself the

1 I.etter from Boston, C.C. $I 689-92,3$ 10. ${ }^{2}$ Bullivant's Journal, ib. 885 .

3 Letter from Samuel Myles, minister at Boston, ib. 1239.

4 Bradstreet to the Lords of Trade, $i b$. 513. Governor-General of Massachusetts to Earl of Shrewsbury, ib. 524.

${ }^{5}$ Bullivant's Journal, ib. 885 .

6 President of Revolutionary Council to the King, $i b .182$.

$7 \mathrm{Ib} .138$.

${ }^{8} \mathrm{Ib} .138$.

${ }^{9}$ Case of Massachusetts colony considered in a letter to a friend at Boston, b. 133 .

10 Letter from Boston merchant to London merchant, $i b$. I29. 
true Israel. 'Nothing will serve their turn but their old charters.' He added caustically: 'A very home-bred people, but exceeding wise and conceited in their own eyes.'

On the other hand, there is considerable evidence to shew that although the most zealous party, the Charterists-to coin a convenient term-did not represent the whole of Massachusetts public opinion. For some the revolutionists were 'a giddy and enraged mob'.' Some urged new elections ${ }^{2}$; 'Andros and the council have worked well and increasingly for the welfare of this country...the charter is void ${ }^{3}$.' Merchants and others asked for the release of Captain George, saying that 'we ought to avoid a revival of the old scandals over the acts of 'Trade and Navigation.' Although James's rule was generous, yet 'the uniting of the colonies added to our happiness;... most wise men agree that the old Charter government was unfit for the people, and dangerous to both King and subject;... it placed unlimited power in the hands of a few to oppress others.' Moreover, the territory was too much broken up; union is better ${ }^{4}$. These are the opinions of some, evidently those outside the favoured circle in the old Massachusetts.

Meanwhile the colony's agents in England were pressing for the restitution of their charter privileges. Phips and Mather, two of the most influential spokesmen for Massachusetts, applied for their old charter as soon as the new government was well established ${ }^{5}$; and in favour of their request it was urged that there had been a flaw in the scire facias of $1683^{6}$. William's advisers, however, did not readily give up all that had been gained under James; and the agents soon accepted the position by making suggestions for a new charter. Their first claims were for the inclusion of Maine and New Hampshire-a union which in responsible hands was certainly necessary for the adequate defence of those outlying parts of New England. For their constitution they asked for restitution of the lands held

\footnotetext{
1 'An Answer to the Account of the Revolution' in Boston, C.C. 1689-92, $18 \mathrm{I}$.

2 Letter from friend in the country to a Boston gentleman, $i b .135$.

$3 \mathrm{Ib}, \mathrm{1} 8 \mathrm{r}$.

4 Letter from New England, $i b$. 1534 .

${ }^{5}$ Phips and Mather to the King, ib. 18.

6 Journal of the Lords of Trade, $i b .25$.
} 


\section{REVOLUTION OF 1689 IN THE COLONIES [CH.}

under the former charter, the election of officers and appointment of the judicature, the right of taxation for support of government, and other smaller details ${ }^{1}$. On receiving these suggestions, the Lords of Trade asked the King's wishes on the subject of the governor's appointment. William replied that he would reserve that appointment to himself ${ }^{2}$. The agents, compelled to bow to this decision, take up a fresh stand on the appointment of the deputy-governor, asking further for a limitation of the time for confirmation or disallowance of laws to 18 months, for freedom in elections or in appointment of the council, without veto by the governor. They also ask that the militia, although under the command of the governor, shall not be moved without consent of the assembly. At this stage the draft charter is submitted, and the agents again find some of their suggestions overruled. They refuse at first to accept an indefinite time for the disallowance of laws, the appointment of judges and justices and sheriffs by the governor, with the assent of his council, the governor's right of approving members of the council after election by the assembly; and his complete veto on all laws and acts of that assembly ${ }^{3}$. Finding however that they must accept these restrictions or lose the whole, they acquiesce shortly after ${ }^{4}$, and confine their suggestions to smaller matters, many of which the government can concede without losing ground. The agents also attempt to force the insertion of vague clauses preserving 'old rights, privileges and properties; and giving an alternative power in official appointments to the Assembly ${ }^{5}$ '

\section{The new charter}

Towards the end of 1691 the new charter was finally passed ${ }^{6}$, and the policy of the new régime thus publicly expressed. It was now evident that the hopes of those who had looked for a return to the old policy of laissez-faire were not to be realized.

1 Proposals of Agents, C.C. r689-92, 1276.

2 Order of King in Council, ib. 1440.

3 Attorney-General on the Minutes for the Charter of Massachusetts ib. $1669-70$.

${ }_{4}$ Journal of the Lords of Trade, $i b$. 1706.

5 Agents to the Lords of Trade, $i b .1724$.

- Order of Queen in Council, ib. 1769, 1806. 
In fact the policy of William seemed closely to resemble that of his predecessor, although one or two concessions were made which it is hard to imagine James yielding, with his more rigid ideas of royal control. Massachusetts became by charter a royal province. The governor and deputy-governor were no longer to be elected but were to be appointed by the King during his pleasure. The general court, or assembly, was constituted by the election of freeholders-as opposed to freemen in the previous system-on the English model, meeting once a year or oftener, summoned by the governor. The councillors, or assistants, were to be chosen by the general court-here is a concession to the colony - and were to advise the governor, who had the appointment of judges, sheriffs, and justices of the peace. The general court could also erect courts of justice, and appoint other civil officers. The governor had control of the militia, but must obtain the consent of the assembly before moving it outside the colony, unless martial law was established, which could be done only with the agreement of the council. Liberty of conscience was granted to all Christians except papists. The time-limit for confirmation of laws was at first indefinite, but was later fixed at three years, instead of the eighteen months proposed by the agents. This charter included Nova Scotia, Maine, and the Kennebec country-the boundary being fixed three miles north of the Merrimac-and also New Plymouth, which had proclaimed William and Mary on first news of the change of sovereigns, and had then proceeded to elect a governor and assistants according to the old charter, 'taken from us by the illegal and arbitrary government of Sir Edmund Andros ${ }^{1}$ '; asking for royal confirmation of their ancient rights and privileges. New Hampshire also, though not included in the charter, had been taken under the protection of Massachusetts at its own request in 1690 , the proprietary government continuing to hold an authority at least nominal ${ }^{2}$. Connecticut, on the other hand, separated itself from the old colony, and elected a new governor ${ }^{3}$; whilst Rhode Island also returned to

1 General Court of New Plymouth to the King, C.C. $1689-92,183$.

2 Elisha Hutchinson to Elisha Cook, ib. 802.

3 Lieutenant-Governor of New York to the Lords of Trade, $i b$. 121 . 
the system in force before the proceedings instituted by James II. Thus the lesser New England colonies took advantage of the fall of James and his lieutenant in Boston to take each the direction of its own inclinations and interests, whilst the greater colony was being systematically reorganized from England. The charter settlement of Massachusetts was for the time completed by the appointment of Sir William Phips as governor, in

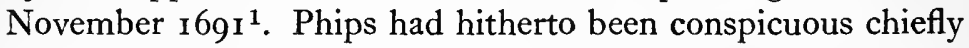
as a searcher after wrecked treasure-ships, but had recently entered the public life of Massachusetts and had commanded the expedition which failed before Quebec early in $169 \mathrm{x}$, after achieving the surrender and plunder of Port Royal, the French station in Acadia. He had taken no part in the revolution, being at that time in England; but was, with Mather, a leading figure in the struggle of the past two years for charter independence; and now took office as governor through the method of appointment which he had struggled to prevent. Under such auspices was the second period of charter-government inaugurated in Massachusetts.

\section{(b) The Revolution In New York}

\section{The outbreak}

In New York, as in Boston, the landing of William of Orange was the signal for a revolution, less dramatic in this case, but more injurious to the colony and to the English cause in America. The lieutenant-governor for Andros was Francis Nicholson, a firm supporter of the system he represented, and later honoured for valuable service under King William. Unfortunately for New York, Nicholson's temper was not always under control; and in a time when the need for tact could not be exaggerated this failing was accountable for much of the subsequent disorder. The unrest began at Long Island ${ }^{2}$ at the receipt of news from Boston telling of Andros' imprisonment; and for several weeks a vague hostility to the government was evident, but for a fortnight the authorities kept control. Rumours

1 Phips's Commission, C.C. $1689-92$, 1916.

2 Declaration of the freeholders of Suffolk in Long Island, $i b .104$. 
spread of Indian attacks, and of war with France; and the government decided to refortify the town, but found themselves at a loss how to raise money. The customs were being decried as illegal ${ }^{1}$. Finally on May 3 Ist the agitation came to a head. While Nicholson and the militia officers were consulting together for the suppression of the disaffected parties, the mob rose, seized Fort James, and gave practical control into the hands of Jacob Leisler, a wealthy militia captain of German birth and Dutch education. At this stage the inhabitants and trainbands of New York issued a statement of reasons for their rising; and declared their intention of holding the fort pending orders from the King. They refused to obey the council's order to deliver to the town clerk the King's money in the fort; and with the treasury in their possession, the legitimate authority of the governor became very slight. Nicholson remained for ten days and then decided that his best plan was to leave quietly for England; and his departure left Leisler's faction supreme. The council met, and passed resolutions appointing commissioners of revenue; but Leisler appeared in force at this meeting and took away the resolutions; whilst one of the commissioners appointed was later beaten and wounded, and Bayard, the aristocratic leader of the council, narrowly escaped being done to death. Those persons who had seized the fort now declared themselves a committee of safety $^{2}$, and gave Leisler a commission as Captain of the Fort; a declaration also being passed against all office-holding under King James' commissions. This self-appointed government was still in power when in December a messenger arrived with letters from the King to Nicholson, or those who exercised authority in his absence. In spite of the protests of Nicholson's late councillors, Leisler appropriated these letters, and now styled himself Lieutenant-Governor and Commander-in-Chief; signalizing this accession of dignity by occupying the governor's pew in church, to the scandal of the more fastidious but less energetic inhabitants of New York ${ }^{3}$. Thus he carried on a kind of government until March $169 \mathrm{I}$,

1 Lieutenant-Governor of New York to the Lords of Trade, C.C. I689-92, $12 \mathrm{I}$.

2 Bayard's Journal, $i b, 216$.

3 Bayard to Nicholson, Shrewsbury and Andros, ib. 630-2. 
when the arrival of Colonel Sloughter, the newly-appointed governor, brought the period of revolutionary government to an end.

\section{Motives for revolt}

The impression given by a study of the revolts in the colonies of Massachusetts and New York is that the New York movement was by far the more unreasoning and unreasonable, lacking the steady purpose which undoubtedly inspired the uprising in Boston. It begins uncertainly with the complaints of malcontents and ends in a disreputable faction. The reasons given for the rising are hollow, and represent little more than a pretext for the events which followed. A declaration was made in the presence of Nicholson, while still in New York, by one Bartholomew le Roux ${ }^{1}$, replying to an inquiry of Bayard. His first reason was that papists were threatening to massacre the settlers in Staten Island, and then to come and burn New York. The accuser produced evidence to this alarm but not to the fact. It was also rumoured that fugitives from Boston, chiefly Irish and papists, were in the neighbourhood, and these were also feared. Many of the regular soldiers were papists, and the defence of the province was thereby not secure; whilst the sailing of Colonel Dongan's brig, fitted out as a man-of-war, also gave cause for alarm. Thus the charges shew a vague fear of papists, which may have disposed the people to acquiesce in Leisler's domination, but can hardly have produced a revolution unaided. At the first rising on May 3 Ist, the inhabitants and trainbands also gave their reasons for revolt: 'Notwithstanding the grievances and oppressions of Governor Dongan and his wicked pensionaries of whom Lieutenant-Governor Nicholson is one,' they were resolved to await King William's decision.

But when we were threatened and cajoled by Lieutenant-Governor Nicholson, when he presented a pistol at our corporal, and told Lieutenant Cuyler that he would set the city on fire because we did our loyal duty, we then for the safety of the Protestants, and in view of the daily coming of papists and soldiers to Lieutenant-Governor

${ }_{1}$ Declaration of Bartholomew le Roux, C.C. $1689-92,45^{8}$. 
Nicholson, resolved to live no longer in such danger, but to secure the fort; which we have effected without bloodshed. We shall now hold it pending orders from the King ${ }^{1}$.

In giving ground for such statements, Nicholson had evidently shewn some lack of caution; and as he was a man of quick temper, the charges are easy to explain as springing from remarks or actions far less violent than those alleged. A further statement made by the militia on June 3 rd asserted that their intention was only to safeguard the Protestant religion until the arrival of ships from the Prince of Orange, when his orders would be promptly obeyed. The rebels also addressed the King and Queen, telling of the oppression under which they had groaned, and the subversion of their 'ancient privileges'; and attributed the rising to dread of Andros, and Nicholson's threat to shoot the corporal and fire the town. Nicholson's behaviour on receipt of the news of William's landing was also used against him: 'He flew into a violent passion and said that Salisbury Plain was burying-place enough for Prince and people too; and threatened to cut off the messenger's ears ${ }^{2}$.' Like Dongan, he fell under suspicion of neglecting to repair the fortifications of the city ${ }^{3}$.

Thus the records point to a common feeling of insecurity and danger under Nicholson's rule, in which circumstances little enough was necessary to provoke an armed rising, for it must be remembered that in the American colonies a revolution was hardly the weighty undertaking that it would be in an old established European state. Given the common agreement of an active and considerable minority, authority could not stand against it. Nicholson could not put down rebellion by force, when his soldiers with the exception of two royal companies, were drawn from the ranks of the insurgents as militia; whilst the majority of the inactive population would be deterred by fear of papists or by personal grievances. As for the home government, by the time that England realized the situation

1 Declaration of inhabitants and soldiers of the trainbands of Massachusetts, C.C. $1689-92$, 160 .

2 Deposition of Andries Greverat and George Brewerton, ib. 671 .

3 O'Callaghan, Documentary History of New York, p. 55. 
and took action, the rising had been utilized by Leisler for the ascendancy of his own mere faction; and, as factious, his rule was brought to an end.

\section{Leislerite policy}

Leisler, on accession to power, made certain requests of the King, seeking approbation for his conduct and asking for a charter similar to the old Boston Charter, for power against rebels, papists and the disaffected, and for general consideration to the province in the matter of government and organization for defence ${ }^{1}$. His rule however was not long in attaining unpopularity. Livingston, the leader of the Albany settlement, described Leisler as prompted by ambition to domineer' ${ }^{2}$ ' $\mathrm{He}$ is a proud, insolent, oppressing fellow-and will certainly ruin the place,' writes a Bostoner to Usher, the lieutenant-governor of New Hampshire ${ }^{3}$. The record of 1690 is a tale of disorder. Leisler and his party spent time in guarding against papists ${ }^{4}$, when they should have been organizing government and guarding against French and Indian attacks. When he attempted to raise taxes on real and personal property ${ }^{5}$, the collection was opposed ${ }^{6}$. When the inhabitants were called upon to renew their association for defence, it was necessary to arrest hinderers ${ }^{7}$. The news of James's landing in Ireland provoked a riot. 'Thirty people also appeared in the street, and struck at the LieutenantGovernor with an adze.' Twenty were imprisoned ${ }^{8}$. The more religious of the population were dissatisfied. 'We live like heathen...neither Church, nor people, nor prayers....We scarce know when Sunday comes ${ }^{9}$ ' In May 1690 , certain inhabitants of New York petitioned the King and Queen for help: 'We are sorely oppressed...under the burden of slavery executed by the men who have overturned all civil power (in defiance of the proclamation), and rule us by the sword, seize our estate without

1 Joost Stoll to the Earl of Shrewsbury, C.C. $1689-92,567$.

2 Livingston to Ferguson of the Excise Office, London, $i b .796$.

3 Letters from Boston to John Usher, $i b .800$.

4 Ib. 218-9, 632, etc.

5 Act of Revolutionary Assembly, ib. 840.

${ }^{6}$ Revolutionary Government to the Earl of Shrewsbury, ib. 955.

? Proclamation and Order of the Revolutionary Government, $i b$. 930-r.

8 Ib. 955 .

${ }^{9}$ Joshua Brodbent to Nicholson, ib. 2283 . 
trial, plunder houses, open letters, abuse ministers of reformed churches, and seize their revenues ${ }^{1}$ ' Flypse and Courtlandt, two of the Council, complain that 'the people are very unruly and daily commit unlawful acts. None pay duty but those who choose....The whole revenue will fail. All is in confusion. Magistrates are threatened and hindered...others called papists and suspects ${ }^{2}$.'

\section{Defence neglected}

Albany, the outpost against the Indians, refused for long to acknowledge Leisler's government. The results of this disagreement were soon seen. In February 1690 , a party of French and Indians fell on Senectady, killed sixty men and women, carried off others, and burnt all the town except six or seven houses. 'The people were so bigoted to Leisler,'says Livingston, 'that they would obey none of the magistrates, or entertain the soldiers sent from Albany, and would not guard ${ }^{3}$.' The town was divided into factions, the gates left open, and not a sentinel posted ${ }^{4}$. In March, Leisler sent a party to Albany to compel its surrender, 'to fetch the mayor and several gentlemen to prison, where he sends all that will not do him homage 5.' In May, Albany was forced to submit, but the mayor and aldermen were continued in authority owing to the fear of Indians. Some others of the population found themselves in gaol ${ }^{6}$.

\section{The end of Leisler}

By the time of Sloughter's arrival, Leisler was fast being forsaken in New York. His period of power had been a gradual descent from the position of Protestant hero to that of deserted rebel; and while he felt his power in New York slipping from him, the English government had persistently ignored his once confident claim to be its representative. The appointment of a new governor left Leisler stranded without position or authority. On the arrival of the first ships containing Sloughter's

1 Inhabitants of New York to the King and Queen, C.C. I689-92, 887.

2 Flypse and Courtlandt to Blathwayt, ib. 3 I9.

3 Livingston to Andros, $i b$. 836 .

4 Allen to Joseph Dudley, $i b$. 807.

${ }^{5}$ Letters to John Usher from Boston, ib. 800.

6 Livingston to the Governor and General Court of Connecticut, $i b .875$. 
escort, Leisler refused admission to the fort to these soldiers, and even went so far as to fire on the King's troops ${ }^{1}$. The governor however refused to treat with him, imprisoned his messengers, and thus induced the last of Leisler's followers to desert their unhappy leader. At last the gates were opened, and Leisler with his chief officers was placed under arrest, to be tried by a special court; and, convicted by this, he and his chief lieutenant, Milborne, were executed ${ }^{2}$. But the province was fated to endure many years of faction after Leisler's death. His trial and execution were carried out in such a way that doubts might easily be cast in later days on the constitutionality of the whole proceedings; whilst popular opinion veered round at his death and created a martyr ${ }^{3}$. For the remainder of William's reign, if not longer, there were two opposing elements in New York politics, the Leislerites and the anti-Leislerites, both of which could point to certain periods in the two years of revolution, and claim the position of loyalists by ignoring the rest of their party record. Later governors threw themselves violently on one side or the other to the great injury of $\mathrm{New}$ York, whilst the bitterness of party feeling, preserved in descendants of the original protagonists, prevented the colony from following its normal course of development.

\section{(c) The Revolution in Maryland}

\section{The outbreak}

At the time of the English revolution, Lord Baltimore, the proprietor of Maryland, was in England, and he received instructions from the Council to proclaim William and Mary in his government. In February he promised to do this, as also did Penn for the Quaker colony of Pennsylvania 4 . Unfortunately, however, for Baltimore, a mishap occurred to the messenger by whom he sent the order, with the result that the proclamation

1 Proclamation and declaration of New York Council, C.C. I689-92, I $347-8$.

${ }_{2}$ Minutes of New York Council and a letter from Leisler to Stoughton ib. $1366-7$.

3 Van Rensselaer, History of the City of New York, Chap. xxix.

4 Journal of the Committee of Trade, C.C. I689-92, 25. 
in Maryland was much belated. Meanwhile, in March, rumours were afoot in the colony that the papists there were concerned in a scheme to hand over land to the Indians; but the council, tracing these rumours to malicious persons, out for the plunder of peaceful citizens, succeeded in temporarily restoring public confidence ${ }^{1}$. For several weeks there was a lull, but in June it was reported that 'the inhabitants, mostly Protestants, are ragingly earnest for the proclaiming of William;...They will not believe that the order has not arrived, and that the government are not concealing it ${ }^{2}$ ' Quietly the Protestant majority asserted their intention to take over the government from Baltimore's officers, and in July they issued a manifesto and established a revolutionary council with John Coode and Kenelm Cheseldyn at its head ${ }^{3}$.

\section{Reasons for the revolt}

The manifesto of $x 689$ is concerned with accusations against Lord Baltimore's government. 'Plots, contrivances and subscriptions carried on and extorted by him and his officers,' with charges of disloyalty, are urged against the proprietor, the instances given being the omission of reference to the King in the oath taken by office-holders, and the ill-usage of revenue officers in two cases. Churches and chapels, it is stated, have been turned to popish worship, the officers of the government are papists-not a remarkable circumstance in a colony originally the refuge of Roman Catholics-half the representatives in convention have been picked by the government, and the King's laws have been enforced only if favourable to the proprietors. In addition, Baltimore has hindered the growth of trade and has suspended the erection of towns. Therefore the 'Protestant subjects of Maryland' have altogether abjured their allegiance to the proprietor and have set up that to the King, and are proceeding to summon a full assembly. The year following this publication, Coode and Cheseldyn again sought to justify their action to the King. In this second document they deny that

1 Minutes of Council of Maryland, C.C. I689-92, 56, 64.

2 Letter from Nicholas Spencer, of Virginia, $i b$. 194.

3 Reasons for taking up arms, ib. 290. 
there was peace under the proprietary government, and repeat the charges of the manifesto, with the addition of accusations of a popish plot and connivance in Indian attacks. Only after William and Mary had been on the throne for five months and still were not proclaimed did the Protestants, according to this letter, take matters into their own hands; and by this time papists were disarming Protestants, conferring with Indians, and spreading false news of James's success, whilst Protestants were forced to take refuge in Virginia. The rising was followed, Coode continues, by a convention from which papists were excluded and to which Protestants were brought back, all the laws were continued in force, the smallest levy on record was made, and the country held for the Protestant interest ${ }^{1}$. A Committee of Secrecy appointed by the convention found that 'the late Popish Governors have contrived conspired and designed... to betray their Majesties' Protestant subjects to the French, the Northern and other Indians'; and decided that their lives and estates were still in danger from this cause ${ }^{2}$; and a petition was sent to the King, asking for a general removal of grievances and oppressions, and the security of religious rights and liberties ${ }^{3}$.

\section{The revolutionary government}

In June 1690 , Lord Baltimore's agent appealed to the provisional government for his proprietary dues; and these were granted with the proviso that a fixed part of the collection was to be carried out by officials of that government ${ }^{4}$. This arrangement however did not work satisfactorily. Coode accused the agent of stirring up disturbance, and defeating his attempts to preserve order ${ }^{5}$. The agent complained that Cheseldyn was spending his master's revenue at Plymouth ${ }^{6}$. In other cases, the conduct of the revolutionary government provoked many complaints. One merchant who 'dared to say what others

1 Coode and Cheseldyn, C.C. $1689-92,1267$.

2 Maryland Archives, xir, p. 240.

3 Address of Protestant Representatives to the King, C.C. I689-92, 406.

4 Correspondence between Baltimore's agent and the Revolutionary Government, $i b .920,947$.

5 Revolutionary Committee to the King, ib. 986.

${ }^{6}$ Petition of Lord Baltimore to the King, $i b$. 1205. 
hardly dare think ${ }^{1}$ ' sought protection from forty armed men who had orders to take him, alive or dead (for 'opposition to their arbitrary and illegal proceedings'), and who seized his ships, dispersed his men out of spite, rifled his house, and destroyed his standing crops ${ }^{2}$. A letter to the Bishop of London contains accusations against Coode of 'seizing the government on pretence of defending it against French and Indians, and now detaining Lord Baltimore's revenue, boasting that the King's commission and their powers will be confirmed, and so threaten us Protestants ${ }^{3}$ '. Another Protestant petition speaks of the long and peaceful rule of the Baltimores, father and son, until upset by Coode and his party 'who seized records with titles of property, seized and plundered our estates, and now maintain themselves in their lawlessness by force, styling all others traitors ${ }^{4}$.'

The true character of Coode is hidden by the abuse of his enemies, but it was certainly not spotless ${ }^{5}$. Nevertheless, his government continued in power with tolerable success until the arrival of a royal governor in 1692 , and there are several indications that his policy compared favourably with that of the temporary rulers in the other colonies. In December 1689 every county sent addresses describing its good posture of defence against French and papists ${ }^{6}$. Coode appears also to have had an agent at Albany to remit what information he could obtain of the French proceedings-an indication that the revolutionary leader was not as blind as some to the need for common action against France?. A letter was also sent to Virginia, and possibly to other colonies, inviting friendly co-operation.

We...having proclaimed King William and Queen Mary, as (we doubt not) you have also done; do in the next place as Friends, Neighbours, and fellow subjects, solicit and court your friendly and neighbourly correspondency upon all occasions, by imparting and communicating to us. .all matters of import conducing to Their

${ }^{1}$ Petition of Lord Baltimore to the King, C.C. I689-92, 922. 2 Ib. 919.

3 Thomas Smithson to the Bishop of London, $i b .975$.

${ }^{4}$ Petition of Protestant inhabitants to the King, ib. 1204.

5 See Maryland Archives, xx, Preface, p. xii, etc., etc.

' Coode to the Lords of Trade, C.C. I689-92, 644 .

- Maryland Archives (Council Proceedings, I687-93), p. 123. 
Majesties' service and the good and welfare of their subjects here,.. and in all things whatsoever to bear us your hearty affections, love and goodwill in all the ways of Friendship, and a mutual good correspondency.

The letter concluded with a promise to reciprocate in the matter ${ }^{1}$. Such a letter is worthy of note at a time when cooperation between colonies was exceptional rather than usual. Moreover the revolutionary leaders also resisted an attempt in 1692 to permit membership of assembly without the necessity of taking the oaths of allegiance and abhorrence in certain cases of conscience. They decided that this could not be done without open violation of the laws of England ${ }^{2}$.

At home, the real issue between Baltimore and the colony was avoided. Proceedings were ordered by scire facias against his charter ${ }^{3}$, and a royal governor appointed as his deputy, with instructions similar to those to the governor in a royal colony ${ }^{4}$; but the proprietorship still held good nominally, and led to much dispute in the colony during the early years of William's reign. In I $_{7}{ }_{5}$ the accession of a Protestant to the title of Lord Baltimore enabled the old system to be fully revived; but while the proprietor was a Catholic, William deemed it wise to choose the governor himself.

\section{(d) The Quieter Colonies}

\section{Virginia}

The news of the English revolution reached Virginia towards the end of April; the governor, Lord Howard of Effingham, being at that time on his way to England. Some malcontents attempted to use the occasion to provoke an anti-papist riot, but the council acted wisely and promptly. The ringleaders, spreading rumours of an intended massacre of Protestants, were arrested and imprisoned on board the man-of-war. One Mason, a magistrate, suspected of encouraging riotous behaviour, was removed from the commission; and the proclamation of William

1 Maryland Archives, xiI, p. 233 et seq.

3 Order of King in Council, C.C. 1689-92, 1026.

4 Draft Commission for Lionel Copley, $i b$. 1297.

Ib. pp. $254^{-6}$ et seq. 
and Mary was carried out in orderly fashion ${ }^{1}$. In May 1690 , Francis Nicholson returned to America as Lieutenant-Governor of Virginia ${ }^{2}$; and two years later the governorship was entrusted to Andros ${ }^{3}$.

\section{New Fersey and Carolina}

Of the proprietary colonies, Maryland was the only one in which a revolution was provoked. New Jersey had quietly returned to the control of those proprietors who had been overruled by James's policy of a united New England. Carolina was disturbed, about the same time, by an insurrection against Sothell, a governor appointed by the proprietors; and the beginning of William's reign coincided with the appointment of Ludwell as governor; but these changes were not the result of the revolution. Carolina had not as yet gone beyond the stage when most of its affairs could be settled by the proprietors; and the new régime was instituted with little comment ${ }^{4}$. As William's reign advanced its importance increased; but chiefly as a haven for undesirables and as a noted transgressor of the trade laws. Politically, Carolina was still a settlement.

\section{Pennsylvania}

Pennsylvania too, throughout this period, resembles a settlement rather than a state, but a settlement of different quality from that of Carolina. The Quakers who founded it seemed to lack that spirit of corporate existence which distinguished the Puritan colonies of New England; they carried on the trade which was rapidly making their country prosperous, and took little share in the political and religious prejudices of the Revolution. Thus the affairs of Pennsylvania during the years of turmoil elsewhere were characterized by oddity rather than importance; whilst the colony's obliviousness to the political issues brought upon them the indignation of their neighbours. Pennsylvania had early news of William's landing, as New York was informed from that source on the ist of March I689; but little of importance occurred as a result. In August, 'two

\footnotetext{
1 Minutes of the Council of Virginia, C.C. $1689-92,91$.

${ }^{3}$ Order of King in Council, ib. 2050.

$2 I b .924$.

$4 \mathrm{Ib}$. III7, 1023, I488, ${ }_{5} 83$, I 886 , etc., etc.
} 
Papist gentlemen from Maryland' appeared in Newcastle, and one magistrate thought that they should be seized. The others however dissented, and after drinking King James's health the visitors were allowed to go ${ }^{1}$. The same magistrate was put out of the Commission because he declined to sit in court until William should be proclaimed. 'When I represented that he had been proclaimed all over America, they answered that if one man had killed another that was no reason why we should do the like ${ }^{2}$.' Pennsylvania was peculiar in the respect that its charter rights were, unlike other colonies, closely bound up with the deposed Stuarts, through the intimacy of their founder with James and his brother. Thus to the Quakers, the rule of James stood for liberty, whilst to others it meant autocracy. Leisler complained that Pennsylvania was becoming the resort of Roman Catholics. 'They encourage if not outdo the Roman Catholics and are the principal cause of our calamities. They assert Penn to be a man of undoubted sincerity, and say that James's commission holds good to this day ${ }^{3}$.' Nicholson too in Virginia was uneasy lest the Quakers should carry on correspondence with French and Indians, and asked for orders to deal with them ${ }^{4}$. Finally in June 1692 Benjamin Fletcher, appointed Governor of New York in succession to Sloughter, had Pennsylvania included in his commission ${ }^{5}$, which gave him power to appoint a lieutenant-governor ${ }^{6}$. 'The government is very loose owing to the Quakers falling out among themselves?'. 'Pennsylvania is in an unsettled state, and should be brought under the Crown ${ }^{8}$.' These are the comments of two neighbouring governors.

\section{Barbados}

In the West Indian colonies, there are no signs of revolutionary ardour. Barbados, under Deputy-Governor Stede, had been troubled lately by the 'popish practices' of Sir Thomas Montgomery and $\mathrm{Mr}$ Willoughby Chamberlayne, who en-

1 Deposition of Jehann Forat, C.C. $1689-92,469$.

3 Leisler and the Council to the Bishop of Salisbury, ib. 690.

4 Lieutenant-Governor Nicholson to the Lords of Trade, $i b .1302$.

5 Ib. 2573 .

ib. 2584 .

7 Nicholson to the Lords of Trade, ib. 2344.

8 Copley to [Earl of Nottingham?], ib. 2472. 
deavoured to procure the appointment of a Roman Catholic governor; but they had been committed ${ }^{\mathbf{1}}$ before William's accession was known, and Roman Catholics declared incapable of public employment, and forbidden to say mass ${ }^{2}$. In May, proclamation of the new sovereigns was made 'in the most solemn, splendid and glorious manner that this poor island could afford.... The noble, stately and no wise ordinary sort of proclaiming their Majesties would have a little surprised you, had you been there,' says Stede, giving full and elaborate details of the festivities ${ }^{3}$. The following year he was superseded by a commission as governor given to James Kendall, whose service to William and Mary was great in Barbados.

\section{The Leeward Islands}

In the Leeward Islands, Sir Nathaniel Johnson was in power. Writing home in December 1688 , the governor stated that he would be of more use to King James in England than here ${ }^{4}$; but on receiving orders from William he made the required proclamations sending in his resignation immediately afterwards with a dignified letter explaining his opinions, but protesting that until his successor arrived he would serve the Islands faithfully ${ }^{5}$. Such an open avowal of loyalty to James could not escape accusation, even in face of Johnson's personal honour; and in July he was accused of an attempt to betray his government to the French at Martinique. The council of Antigua however expressed their faith in Johnson ${ }^{6}$, but deemed it wise that his resignation should be accepted; and ten days later the command devolved on Christopher Codrington as LieutenantGeneral, later commissioned Governor ${ }^{7}$.

\section{Famaica}

In Jamaica also the revolution was peacefully accomplished. The corruption of administration during the governorship of the

1 Minutes of Council of Barbados, C.C. $1689-92,34$.

2 Orders of Lieutenant-Governor in Council, ib. 35 .

3 Deputy-Governor Stede to the Earl of Shrewsbury, ib. 155, I 58.

4 Letter from Sir Nathaniel Johnson, $i b .88$.

5 Johnson to the Lords of Trade, $i b$. 143 .

B Council and Assembly of Antigua to the Lords of Trade, ib. 255.

7 Codrington to the Lords of Trade, $i b .3$ 12, 445-6. 
Duke of Albemarle in James II's reign, had been condemned by the King before his deposition, and all Albemarle's acts reversed. William reiterated this condemnation ${ }^{1}$. Two governors appointed in succession, Molesworth and Inchiquin, both died before they had been long in office; and the task of reorganizing the affairs of Jamaica after the great earthquake of 1692 was given over to William Beeston ${ }^{2}$, whose deserving efforts make up, with those of Kendall and Codrington, a trio of singularly efficient administrations which the reign of William III bestowed on the West Indian islands.

\section{(e) The Colonial Importance of the English ReVOLUTION}

\section{The independence of the colonial revolutions}

The development of colonial policy before the Revolution had shewn that it was largely independent of the domestic policy of the crown, or at least that the questions at issue in England were so far different from the question of the colonial relationship that changes of dynasty, brought about at home, could not be guaranteed to produce any change in colonial government. The restoration had not the effect of bringing back the method of treatment in vogue before the Great Rebellion. The biggest development hitherto seen in colonial policy had come about in the closing years of Charles II's reign and had been carried on by his brother. It is therefore incorrect to assume that in 1689 revolutions in the colonies were bound to reflect the revolution at home or even to occur at all.

Moreover, few of the colonies were at that time political entities capable of revolution. In the West Indian islands, the governments were small, and the white population little more than half of the whole ${ }^{3}$; whilst political feeling was practically absent. The vital questions were those of production and of export duties on produce 4 . Private interests reigned supreme, as is unfortunately too often evident in the conduct of governors.

1 Prince of Orange to the President of Jamaica, C.C. I689-92, 6.

I Ib. 2398.

${ }^{3}$ Higham, Leeward Islands, Chap. vil.

${ }^{4}$ Beer, Old Colonial System, Vol. II, Chap. x, p. 2. 
There were few to revolt, and little to revolt against. On the mainland the same applies to the lesser colonies. Carolina was still a mere settlement, with private interests paramount. New Jersey was small and divided. Pennsylvania had been founded only seven years, and as yet the settlers' interests were those of the proprietor, both peaceful to an exceptional degree.

Of the stronger colonies, Virginia was under royal government and there was little political feeling against that government, little change that a new King in England might be expected to bring about. Virginia did not fear union with other colonies; only the less important objected to that. And the cultivation of tobacco, with absence of proprietary rights, meant that Virginia fitted into the existing system as well as she was likely to fit into any. The same might have applied to Maryland, had it not been for the proprietary rights of the Baltimores, which, associated as they were with the religion of the minority, proved irksome enough to induce a mild species of revolution. In New York and New England, there existed a definitely objectionable system of government. Especially in Massachusetts, but also in Connecticut and Rhode Island, there was strong division of feeling between the supporters of the old charter and the representatives of the new centralized government. In these circumstances, revolt was worth risking. The two lesser colonies, joined to the greater in a forced union, were almost unanimous in their independent ambitions, and did not need to use force when Massachusetts had destroyed their tyrant for them. All they needed to do was quietly to resume their cherished privileges. New York, too, in a less degree shared the resentment of New England, but there party feeling was a more considerable factor. Twenty-five years previous, the colony had been Dutch, and the enmity of the two nations was not yet dead $^{1}$; whilst the Dutch element undoubtedly contributed much to the New York revolution ${ }^{2}$. New York therefore waited until news of Andros' imprisonment arrived, and then overturned the government, substituting the rule of faction

1 See below, p. 120.

2 For example, at least half of the soldiers defending the fort under Leisler, were Dutchmen (C.C. I689-92, 162). 
more acrimonious and more unfortunate in its results than the zeal of the New England colonies. Moreover, in tracing the causes of the revolutions, it is worthy of note that the serious revolts occurred in those two colonies which had for their capitals the already important towns of Boston and New York. Towns are notorious breeders of revolution, and there is nothing in the history of the colonial outbreaks to belie that tradition.

\section{Effects of the revolution}

It would be premature here to discuss at length the effects on the colonies of the revolution in England, but one or two points already emerge. The government of James II, and Andros under him, clearly stood for union and centralization. Of these, union was undoubtedly delayed by the change of rulers. William was forced by the logic of his position to refrain from following immediately the example of the deposed Stuarts; and the colonies were once more divided. But whether the result was beneficial or the reverse depended on the ability of James to carry out his plans. Failure at that stage would have been disaster; and yet there were many obstacles, not the least being those which geographical position places in the way of scattered settlers in a new country. William had at any rate the advantage of James's unpopularity; and by tactful government might preserve the reality of the old control, while removing its irksomeness. As for centralization, the second of James's objects, here also there arises the problem of possibilities. The effect of overthrowing the Stuarts was to overthrow an attempt at central control, and to make possible the rise of assemblies, and the disorder of factions, under a limited monarchy. Again, could James have avoided this in the long run, and would not failure have been more sudden and disastrous than under a wise administration of the new system?

Finally, there is the question of the French war. In James's reign, all was tending to war. The frigid politeness of Denonville, the stubborn pertinacity of Dongan, concealed only superficially the undercurrent of war, which was already going on through the Indian nations. The expansion of French and English colonization was fast bringing them to an impasse. 
Moreover, one of James II's great achievements was his care for the British navy; and the growth of the navy threatened war, sooner or later. The accession of William of Orange made this position logical. The determined opponent of Louis XIV in Europe became the determined opponent of Louis in America. Instead of hostilities inadequately explained away by diplomatists, instead of treaties of neutrality that neither side believed in and neither intended to observe, the accession of William the Dutchman began that struggle in the New World which was not to end until one of the combatants had been driven from the continent. 


\section{CHAPTER III}

\section{THE WAR WITH FRANCE IN NORTH AMERICA}

The burden of defence was not adequately supported, since neither England nor the colonies wished to bear the whole. Expeditions, both local and imperial, were mismanaged and fraught with difficulty. The position of England after the Revolution demanded a strong imperial policy; but this conflicted with the ideas of representative government and limited monarchy brought in by the new régime.

\section{(a) The Declaration of War}

\section{The position in 1689}

The position of English and French in North America in $\mathbf{1} 689$ was such that the attempt to arrange it by a series of treaties of neutrality was predestined to failure. Towards the end of 1686 , the representatives of the two countries had met at Whitehall and formally agreed to preserve peace and good correspondence upon the lands and seas of America. Neither of the parties would violate the territories of the other in America or the West Indies no matter whether peace or war reigned in Europe ${ }^{1}$. It was soon evident that such a truce would be observed only so long as it coincided with the inclinations of both parties. On the one hand, France did not scruple to attack the Indian allies of England; on the other, the French Indians did not hesitate to raid English territory ${ }^{2}$. Moreover, the perennial source of dispute was still open. In Hudson's Bay, both nations had some ground for claiming a share in occupation and trade. The territory had been discovered by Englishmen, and trading settlements planted later, with several forts, as the headquarters of the Hudson's Bay Company. France however had sent traders to the region before English merchants had appeared on the scene, and with this claim of priority in trade, though not in discovery, established the Company of the North which captured in 1686 three of the four English forts, thus gaining

1 Channing, Hist. of United States, Vol. II, p. 149.

2 Nicholson to Blathwayt, C.C. $1685-8$, 1877 . 


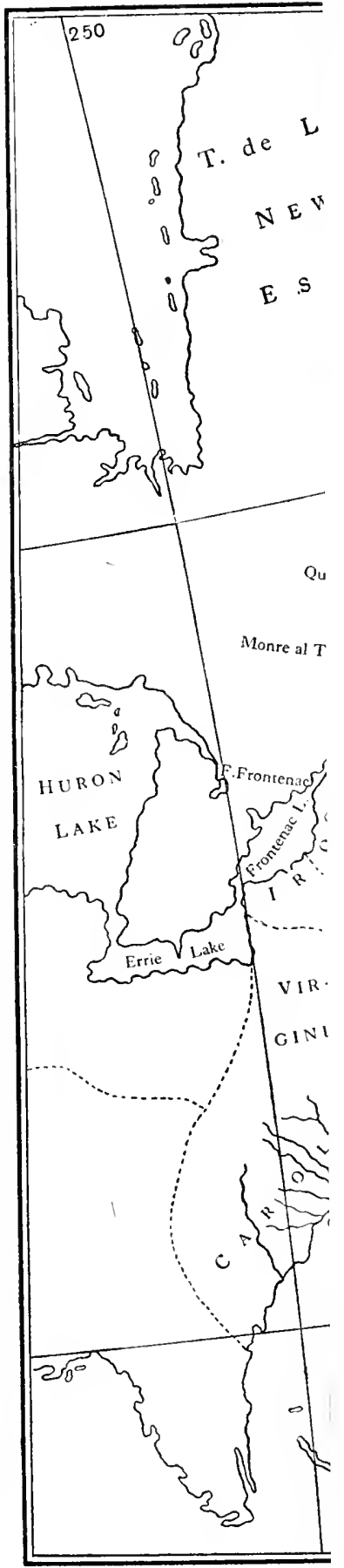

rea

tly

icy

'pi,

-3 ;

)ng

id;

'est

ralf

the

by

but

her

of

by

ich

out

Nas

(a); of her ne, irly of iies 100 ınd ew zen by of to led ere

VII.

89.

IX. 
The b nor th imperi Englat conflic broug!

Th

was $\mathrm{s}$

neutr

the $\mathrm{r}$ and $\mathrm{f}$

upon

wouk

West

It wa

so lo:

On tl allies

hesitc

sourc

had s

The 1 settle

of th

trade

on th

not is

captu 
a large part of the fur trade ${ }^{1}$. But apart from this disputed area where Louis's subjects were boasting that they would shortly take both New York and New England ${ }^{2}$, the French policy was everywhere aggressive-on the west down the Mississippi, following the exploration of $\mathrm{La}$ Salle to Louisiana in $\mathrm{I} 682-3$; on the north-east from Acadia into Maine, on the north among the Indian tribes between Canada, New York and New England; on sea, in the fisheries of Newfoundland; and in the West Indies, in the divided island of St Kitts, half French, half English. The fact that complaints of non-observance of the truce came chiefly from the English side is explainable not by a higher morality in the observance of treaties by England, but by the naturally aggressive policy of France, due partly to her situation on the American continent, but also to her ideas of colonial organization and empire. This fact is illustrated by the length of the struggle between the small population of French Canada, and the English settlers in America, numbering about twenty times as many (the population of New York alone was in 1689 half as great again as the whole population of Canada); but scattered and not organized for defence. The lack of aggressiveness shewn by British colonists needs no further proof than is given by the story of the war begun at this time, in which their inability to organize their greater force is clearly evident; whilst in French Canada the more compact body of settlers some 12,000 in number, included thirty-two companies of regulars ${ }^{3}$; and even though their ranks were reduced to $\mathbf{I} 400$ under Denonville such a body formed a compact defensive and offensive force, the like of which was notably absent in New England. The English Indians, on the other hand, were keen to fight, and were fretting at the restriction placed on them by their European allies. Randolph, writing at the beginning of I689, stated that there were rooo Indians and more, ready to loose on the French when tidings of war should come. He added also, with too sanguine expectation, that ships and men were at hand to drive the French out of the continent ${ }^{4}$.

1 Parkman, Count Frontenac and New France under Louis XIV, Chap. vir.

2 Petition of the Hudson's Bay Company to the King, C.C. I689-92, 89.

3 Parkman, Count Frontenac and New France under Louis XIV, Chap. IX.

1 Randolph to Sir James Hayes, C.C. 1689-92, I. 


\section{Declaration of war}

In April, William informed the colonies of his intention to declare war on France, and within a few days forwarded news of the actual declaration ${ }^{1}$. Among the reasons cited in this document appear the colonial grievances. Although, not long before, the French took licences from the English governor of Newfoundland, to fish there, with payment of tribute, yet in recent years their encroachments on the territory and fisheries of that island were more like the invasion of an enemy than the permitted entry of a friendly nation. The actions too of the French king in invading the English West Indian Islands, especially St Kitts, and in possessing himself of English property in New York and Hudson's Bay, were actions not becoming even an enemy; and yet Louis at that time was soliciting a treaty of neutrality for the American dependencies of both powers. Finally, the declaration proceeded, the seizure of English ships by French privateers, the prohibition of English goods by order or by restrictive duties-these were sufficient evidence of the French intention to destroy the trade and navigation upon which the wealth and security of England depended ${ }^{2}$. On these grounds, the war with France began. For the purpose of carrying on a successful campaign in America, the Lords of Trade immediately met and submitted recommendations for the conduct of the war $^{3}$. They suggested the despatch of ships to disturb the Newfoundland fisheries; the appointment of a new governor over a united dominion of New England, New York and New Jersey; and instructions for the proprietary governments to be put in a fit state of defence; urging throughout the necessity for the colonies to take the offensive. The effect which these recommendations had upon the English war policy shews only too well that the Lords of Trade were but an advisory body, with power to suggest but not to carry out.

1 Circulars to Governors of Colonies, C.C. I689-92, 69, 70, 76-9.

2 See Macpherson, Annals of Commerce, Vol. II, pp. 635-6.

3 Journal of Committee of Trade and Plantations, C.C. I689-92, 90. 


\section{(b) Defence and Offence in America i689-93}

\section{Neglect of defence}

The revolution had disorganized arrangements for defence in the colonies. In April, the Massachusetts Council of Safety had sent an officer to take command at Pemaquid, the outpost against French and Indians, far up north on the coast of Maine, with orders to withdraw some of the forces. At his appearance, Andros' garrison of $x 5^{\circ}$ men deserted, with the exception of about 30 , who were refused admission and marched away. The two officers in command were seized, but the people of Pemaquid refused to let both go, and kept the junior, a Lieutenant Weems, insisting that he was no papist and should be commander. ' $\mathrm{He}$ had not full command, but acted as adviser, the soldiers doing what they pleased.' By August, the Indians found out the state of the garrison, and a party of some 300 Abenakis attacked the fort, there being at that time about 16 men, with plenty of ammunition. After a day's siege, Weems surrendered for the sake of his garrison to the jubilant Indians, all well-armed with 'new French fuzees, waistbelts and cutlasses, grey and black hats on their heads, and some with coloured wigs.' 'They looked on this success as but a beginning; and boasted that they would have all the country by-and-by ${ }^{1}$. About the same time, the Indians were making constant raids on homesteads in the Piscataqua country, destroying many families ${ }^{2}$. Randolph in September sent a list of raids up to date, and the list is a formidable one ${ }^{3}$. The advantage of Indian support, however, worked both ways. Canada was still shaken by the Iroquois descent on La Chine, near Montreal, in the previous autumn, a raid described by Parkman as the most frightful massacre in Canadian history ${ }^{4}$. Moreover, when Count Frontenac, the popular governor of Canada, determined to signalize his return

1 A short account of the condition of Pemaquid, C.C. r689-92, 316. Also Parkman, Frontenac, Chap. x.

${ }^{2}$ Extracts from letters from New England, C.C. $1689-92,336$.

3 Randolph to the Lords of Trade, ib. 407.

${ }^{4}$ Parkman, Frontenac, Chap. Ix. 
after seven years' absence, by the conquest of New York, the Five Nations of the Iroquois were a main cause for the failure of that scheme. They had been authorized to carry on war as allies of England soon after the declaration of war ${ }^{1}$, and Frontenac preparing for his great expedition, was met by the news that the fort called by his name on the northern shore of Lake Ontario had been destroyed by Corlaer's Indian allies ${ }^{2}$.

The fall of Andros had put heart into the French Indians. The tightening control he was beginning to achieve over them, by means of trade and defences, relaxed on his arrest; and the French did not miss the opportunity, the more when Frontenac's return in place of Denonville substituted aggression for diplomacy, Massachusetts was harassed by the Indians near Port Royal and Penobscot, supplied with French ammunition; and any attempts to guard against these raids were rendered difficult by means of the wide rivers of northern New England, which the raiders crossed in portable canoes, thus defying pursuit. Among the Five Nations themselves, French influence had apparently some effect. The Onondagas shewed hostility in one of the frequent sporadic massacres, and the French were credibly reported to be the chief promoters of this ${ }^{3}$; whilst English trade in that quarter suffered correspondingly, the whole beaver trade being threatened by the disaffection ${ }^{4}$. With this situation the revolutionary governments were not best fitted to deal. At Boston, it was found difficult to raise any force. 'The news of war has caused great alarm, for we have no head to command us in case of attack, everyone being Captain ${ }^{5}$.' In addition, no public treasury was found in New England upon the revolution, and the stores of ammunition very inconsiderable $^{6}$. At New York, Leisler raised about fifty men in the fort, and made a battery, stockades, and other defences 'out of the material we provided, and just as we had ordered it,' complains one of the council ${ }^{7}$; whilst the Mohawks from Albany

1 Letters from New England, C.C. $1689-92,316-20$.

2 Parkman, op. cit. Chap. $x$. $3 \mathrm{Ib}$.

1 Petition of merchants trading to New York to the Lords of Trade, C.C. I689-92, 646 .

5 Courtlandt to Nicholson, $i b .322$.

6 Bradstreet to the Lords of Trade, $i b .513$.

7 $I b .322$. 
were given new coats and laced hats, 'and seem to promise not to help our enemies against us ${ }^{1}$.'

But the revolution, which in Massachusetts lost Pemaquid, did not go unpunished in New York. Senectady, the outpost of Albany and of the whole colony, had embraced the faction engendered in New York. Government was in disorder, defence in chaos. On the 9 th of February 1690 , the gates were open and undefended, even unwatched. When the town was asleep, a party of some 200 French and Indians descended on it, killing 60 of the inhabitants, capturing others and burning a great part of the town to the ground ${ }^{2}$. Leisler from New York and Livingston from Albany, regarding the event from different standpoints, described the massacre. The revolutionary leader ${ }^{3}$ blamed his New England neighbours for withdrawing their garrisons from the town and refusing to share expenses of defence. Livingston ${ }^{4}$ set the blame of unreadiness on the people 'so bigoted to Leisler.' The Maquas faithfully pursued the raiders, says Leisler; after three days' persuasion induced them to start, adds Livingston. But however the blame be divided, the sack of Senectady does not add credit to the pages of New York history. Moreover Senectady did not stand alone. It was followed by the loss of Newichewarnock and Salmon Falls, both of which places were taken with ease; ' not a man in the principal fortifications. They beat us, and took a third more than their own number. At the first volley, forty of our men ran away, and but for the bad light, the rest had been cut off ${ }^{5}$.' 'The loss must be attributed chiefly to our own deadly security, and the enemy's treachery,' says Bradstreet ${ }^{6}$.

\section{Designs for attack}

The people of Massachusetts and New York soon realized that they could not rest in inaction; and at the erd of March Bradstreet writing home, stated that they had stirred up the

1 Letter from Boston, C.C. $1689-92$, 509.

${ }^{2}$ Daniel Allen at Boston to Joseph Dudley, ib. 807. Also Parkman, Frontenac, Chap. xI.

${ }^{3}$ Leisler to the Bishop of Salisbury, C.C. $x 689-92,805$.

4 Livingston to Andros, $i b .836$.

5 Letters from Boston, ib. 826.

6 Bradstreet to the Earl of Shrewsbury, ib. 797.

GCP 
Maquas against the enemy, and were resolved on an expedition against Port Royal in Acadia,

it being the general opinion that the Indian war cannot be stopped, nor peace for England, without the removal of the French. Success will greatly encourage an attack on Canada, if the King will assist us with shipping and a speedy supply of ammunition, of which we have hardly enough to furnish the present expedition ${ }^{1}$.

Boston took up the idea. Sir William Phips promised to raise 500 men, and the ships to transport them, and it was hoped that general enthusiasm was great enough to do away with any need for impressment. An immediate attack on Canada seems even to have been intended, had it not been for a great shortage of arms and ammunition. 'If the King would provide two frigates, arms and ammunition, this would easily be accomplished, for the French have not above 3000 men, soldiers and others, in all Canada, and they are all dispersed ${ }^{2}$ ' However, Boston continued to make active preparations for the lesser expedition ${ }^{3}$. This was in April. Phips set sail for Port Royal, which had played so great a part in crippling English commerce as to gain the title of the Dunkirk of America ${ }^{4}$ : and early in May the expedition was successful, meeting with little resistance. 'We cut down the cross, rifled the Church, pulled down the High Altar, and broke their images...kept gathering plunder all day... I reduced Acadia in three weeks,' wrote Phips ${ }^{5}$. But the merchants of Boston, thinking more of cost than of military achievement, were disappointed. Phips' expedition was found wanting, when the cost proved to be $£ 3000$ more than the plunder ${ }^{6}$. To merchants and soldiers alike, plunder was no secondary object in these campaigns. The fall of Port Royal was moreover counterbalanced by reverses in Maine. In mid-May Casco was captured, and this loss represented more to Boston than did the gain of Port Royal. Defence had been in the hands of about 80 soldiers, so quartered in several garrisons that they could

1 Bradstreet to the Earl of Shrewsbury, C.C. I689-92, 797-8.

2 Elisha Hutchinson to Elisha Cook, ib. 802.

${ }^{3}$ Daniel Allin to Joseph Dudley, ib. 807.

4 Macpherson, Annals of Commerce, Vol. II, p. 646.

5 C.C. $1689-92,914,1417$.

6 Letter from a Boston merchant, ib. 1282 . 
not support each other. 'The charter-government cares little for the Piscataqua country,' wrote the late Attorney-general ${ }^{1}$.

While the Acadian expedition was thus successful, the New Englanders were making arrangements for the attack on Canada itself. On the Ist of May I690, a meeting of commissioners from various colonies decided on a cooperative attack, the land forces being composed of 400 men from New York, I60 from Massachusetts, 135 from Connecticut, and 60 from Plymouth, with a less certain promise of 100 men from Maryland. The chief officers were to be appointed by the colonies in order proportionate to the numbers sent; and arrangements were further made to prevent this force being used for any other purpose, or being subjected unduly to the influence of any one colony $^{2}$. Boston agreed to send forces to the attack by sea, under Phips, and Leisler stated his intention of contributing two ships to this force, if they could possibly be obtained. Leisler, indeed, appears to have considerable responsibility in this plan of combined attack ${ }^{3}$. Letters from New England assert that the governor and deputy-governor of Boston were against the expedition, but the people announced that if they would not consent Massachusetts would declare for a general governor of New England 4 . In August, I690, the expedition started. A force of about 2000 English and Indians, of which the Indians numbered some I500, left Albany for Molitreal, under the command of Colonel Winthrop, of Connecticut. Phips, with a slightly larger force, in 32 ships, set sail about the same time for Quebec. The attack was a complete failure. The land forces quarrelled, from various reasons. They were held up by lack of canoes and provisions, and after a small provocative raid and massacre, returned to Albany, where Leisler arrested Winthrop and imprisoned him until a mutiny of the troops compelled his release, Winthrop declaring that he would give no more assistance until a governor arrived ${ }^{5}$. Meanwhile, after a protracted voyage up the St Lawrence, the sea force arrived at Quebec, and Phips demanded surrender. Frontenac himself

1 Letter from Thomas Newton, C.C. I689-92, 899.

2 Ib. 865 .

3 Leisler to the Bishop of Salisbury, $i b$. 805.

4 Letters from New England to Joseph Dudley, $i b .984$.

${ }_{5}$ Nicholson to the Lords of Trade, $i b$. 1164. 
gave the refusal, and compulsion was found to be impossible. According to Phips' account ${ }^{1}$, he landed a considerable party and scored a small success, but disease broke out in the fleet, and the expedition withdrew, cold weather speedily preventing any chance of success. Phips put his losses at 30 or less: the Paris gazette at 500; whilst Sloughter detailing the expedition estimated a loss of 1000 by sickness and shipwreck, 'and not a blow struck for want of courage and conduct in the officers ${ }^{2}$.' The minister at Boston leaves on record the tale of a disgraceful flight to the ships, leaving cannon, drums and colours to the enemy $^{3}$. Some of the vessels returned with half their crew, some with not one healthy man on board. The complaints of neglect with which the survivors were met at Boston have already been mentioned ${ }^{4}$. At New York there was fear of bloodshed, the men being so much abused that they refused to serve again. As a result of the failure, Massachusetts was saddled with a debt of from $£ 40,000$ to $£ 5^{\circ}, 000$. 'On leaving Quebec,' says Phips, 'I received several messages from Frenchmen of the best reputation, saying how uneasy they were under French administration, and how willing they would be to be under their Majesties ${ }^{5}$ '

\section{Defence}

The abortive expedition to Quebec was the last offensive of the war. From this time forward, aggressive plans failed to produce even an attack on the French strongholds; and the whole energy of the colonists was confined to defensive operations and small skirmishes. Virginia was in constant alarm because of the French and Indian depredations. The system of defence in that colony consisted of four small guards of 14 men, each at one of the main river heads, where raids of Indians were likely to be presented ${ }^{6}$. Assistance in ammunition had been received from England since the revolution ${ }^{7}$; but Nicholson, who arrived as lieutenant-governor in 1690 , was not satisfied with the defences of Virginia. 'Some of the places

1 Phips' account, C.C. 1689-92, 1417.

2 Sloughter's account, ib. 1373 .

4 Above, p. 22.

3 Myles' account, ib. 1239.

W. W. Hening, Statutes at Large, 1691 , pp. 82, x $x_{5}, x_{3} 6$.

7 Minutes of the Council of Virginia, C.C. $1689-92,995$. 
called forts do not deserve the name'; there was difficulty in maintaining the standard of discipline in the small river head stations $^{1}$, whilst the men were ill-armed because of poverty, and forts were too expensive to erect. The colony therefore appealed to the King for assistance in this direction, and also for a royal frigate ${ }^{2}$. Moreover, Virginia was uneasy because of the disorder in New York, and begged an early settlement of that province ${ }^{3}$. Fears were not confined to Virginia. The President of Pennsylvania also wrote saying that the colonies could come to no agreement, as was necessary for defence, by reason of the condition of New York ${ }^{4}$. Pennsylvania however did not show determination to override the obstacle. Her inhabitants were without arms, and without permission to use them ${ }^{5}$, whilst in $\mathrm{r}^{6} \mathrm{~g}_{\mathrm{I}}$ they were accused of declaring that they would not fight even if their country was invaded ${ }^{6}$. Such a declaration was hardly calculated to improve the cooperative spirit of defence.

\section{Sloughter's governorship of New York}

In March I69I, Colonel Sloughter, the new governor of New York, took over command of that disturbed province. His appointment had been made in September I689, but he was unable to start until the following June. From June to December he waited for two companies of infantry which were being sent out to recruit the New York forces; and after a delay at Bermuda, he arrived at last in March of the following year, with his two companies, of which the roll of one shows $4 \mathrm{I}$ privates, the other 60 , the usual complement of each being 100?. Sloughter soon set to work, and held a conference with the Five Nations ${ }^{8}$, who promised to carry on a vigorous war; but asked for guns and ships to attack Canada, and expressed surprise at the inaction of Virginia, Maryland and New England-a reproach constantly made by the Indian nations, and too often justified. Some of the Indians were feared to be unreliable, whilst Albany

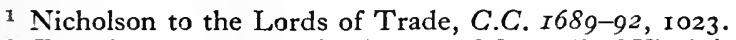

$2 \mathrm{Ib}$. $1 \mathrm{1} 64$.

$4 \mathrm{Ib} .1023$.

3 Minutes of Council of Virginia, $i b$. 1290.

6 Minutes of Council of Virginia, $i b$. 1324.

: Roll of Companies, $i b$. 1016-7.

8 Answer of the Five Nations to Governor Sloughter, $i b$. 1553. 


\section{WAR WITH FRANCE IN NORTH AMERICA [CH.}

was in a state of panic, there being not a hundred men in the town ${ }^{1}$. Sloughter therefore proposed another offensive, by a joint attack on Canada, and submitted this scheme to the other colonies. In reply, Connecticut urged that it was too late in the season and that commissioners should be appointed; adding a complaint concerning the treatment of their men raised for the New York frigate in the previous expedition ${ }^{2}$. Massachusetts, asserting its willingness as ever, protested that it had not the power to help ${ }^{3}$; and the last attack had certainly fallen heavily on Boston; it had resorted to the issue of paper money to meet the financial difficulty, and this paper was now at only 65 per cent. of its face value 4 . However Sloughter appealed again for help, asking this time for 150 men from each of the seven larger colonies. The New Englanders this time definitely refused, pleading a great shortage of stores ${ }^{5}$. The other colonies dallied with the request, until the project fell to the ground with the death of Sloughter in July of the same year as his appointment ${ }^{6}$. Thus New York again had the misfortune to be without a leader, while active preparations were proceeding at Montreal, apparently for a descent on that luckless colony. An expedition under Schuyler had left Albany in June, to meet this danger; but he was troubled with Indian desertion and with the failure of other Indians to appear as promised; and this attack achieved very little ${ }^{7}$. Another setback was given by the loss of a party of some 30 Indians of the Five Nations, engaged in a skirmish and cut off, to the consternation of the English Indians, always liable to waver, at an English reverse. New York was, in short, in very low water during the early months of 1692 . Refusals of help arrived from Virginia, Maryland and New England, although Virginia sent $\oint_{100^{8}}$. Major Ingoldsby, the acting commander at New York, after urging the union of Connecticut

1 Letters to Sloughter from Dirck Wessells and Livingston, C.C. I689-92, I6ro-1. 2 Secretary of Connecticut to Sloughter, $i b .1_{585}$.

${ }^{3}$ Governor of Massachusetts to Sloughter, $i b$. 1586.

4 Letter to Usher from New England, ib. 1309.

${ }^{5}$ Council of New York to Lords of Trade, $i b .167 x$.

${ }^{6}$ Circular from Sloughter to Governors of Virginia, Maryland, Pennsylvana, West Jersey, Connecticut, Rhode Island, and Massachusetts, $i b .1638$.

7 Schuyler's Journal, $i b$. 1684 .

${ }^{8}$ Letters from the Commander-in-Chief at New York, $i b .1987,2191$. 
and New Jersey to that province to ensure more united action on this section of the defences ${ }^{1}$, complained that he himself had received no pay, that the Albany fortifications were out of repair, the people discontented, the Indians weary of the war, and all out-settlements forsaken ${ }^{2}$. When in September, Benjamin Fletcher, the new governor, arrived ${ }^{3}$, he found difficulties enough to try even his determination.

\section{Phips in Boston}

Meanwhile, in spite of Boston's decisive answer to Sloughter's appeal, Phips was writing home, suggesting another attack on Canada ${ }^{4}$. He was in need of a good frigate, a considerable number of cannon and mortars, with large supplies of powder and small arms. If these could be sent from home, he would undertake to find ships and men to preserve Nova Scotia and reduce Canada. In September he enlarged his request to include a whole squadron; and two months later, in response to one of his many requests, Phips was commissioned Governor of Massachusetts, and Commander-in-Chief also of Connecticut, Rhode Island, and the rest of New England, his command including all land and sea forces of those colonies and settlements ${ }^{5}$.

It is difficult throughout such a spasmodic and disjointed war as that waged in the colonies under William III to find clear lines of demarcation. The only grouping which readily suggests itself is based on certain outstanding characters who influence the policy of different periods of the war, for good or ill. The period which ends with the arrival of Fletcher may therefore be called by Phips' name. That rough, quarrelsome sailor had still an important part to play, but for the future he was overshadowed by his equally obstinate and more able contemporary, Fletcher. In one respect however all periods arc alike during the war. Whoever the governor may be, or whatever the colony,

1 Major Ingoldsby and the Council to the King and Queen, C.C. I689-92, I69I.

2 Speech to the House of Representatives, New York, $i b .2392$.

${ }^{3}$ Fletcher to Blathwayt, ib. 2459.

4 Phips' proposals against Canada, ib. 1600-1.

5 Phips' Commission, ib. 1916. 
the question of defence is a problem, and a problem which no authority-government, governor or assembly - can solve, for the simple reason that willingness to act and ability to do so never coincide.

\section{Arrival of Fletcher and his difficulties}

As was invariably the custom of zealous colonial governors sent out from England, Fletcher signalized his arrival by a general denunciation ${ }^{1}$. He found the inhabitants discouraged by the burden of Albany - they were 'a divided, contentious, impoverished people.' The royal frigate, H.M.S. Aldborough, was 'a great expense to the King and no advantage to this place, having neither force to fight nor heels to run, and rides in harbour till she is worm-eaten.' And while thus dissatisfied, Fletcher was receiving reports of recruits and ships sent out to Frontenac. He therefore marched a force of militia to the frontier, but feared that such feeble efforts could not long avert disaster. 'It seems to me utterly impossible for this single province to support the war another year.' In October however the Queen sent orders to New England, Maryland, Virginia and Pennsylvania to assist New York, deciding between themselves the quotas to be sent from each colony ${ }^{2}$; and in view of reports from Pennsylvania, a commission was issued the same month by which Fletcher was appointed governor of that colony in addition to his other command ${ }^{3}$. On news of this appointment Penn wrote to warn the new governor to walk warily in his proprietary colony ; and indicated in part the reason for Fletcher's appointment, by alluding with indignation to current rumours which stated that the French would be allowed to make their way into New England through the pacifist colony ${ }^{4}$.

A further difficulty in the complicated problem of defence lay in New Hampshire, which was garrisoned from Massachusetts. Usher, the proprietary lieutenant-governor, appealed to Boston for a larger defending force, complaining that those men already sent out were not placed under the proper authorities, but under private persons who, while disaffected to himself, were yet

1 C.C. $1689-92,2459-62$.

3 Ib. 2573 .
2 Ib. 2543-4.

4 Penn to Fletcher, ib. 2667. 
favourable to the claims of Massachusetts ${ }^{1}$. At the same time, he could not raise money for their support ${ }^{2}$; so that Phips was able to make the obvious answer: 'If you cannot support 6o, you cannot 120,' adding characteristically: 'The King's affairs shall not suffer by my being buzzed in the ears by evil-minded and prejudiced persons-with all respect to yourself and the Council ${ }^{3}$.' However conclusive the logic of this answer, it did not solve the difficulty, and thus New Hampshire remained inadequately defended. The colony received stores from England, but constantly complained of the negligence of Massachusetts, asking to be joined to that province so that there could be no excuse for refusal of help 4 . In Rhode Island also, there was disagreement. Phips endeavoured to establish his commission over the militia, but the council refused to appear, and the president, although polite, evidently supported the majority ${ }^{5}$. At the same time, Massachusetts tried to put the burden of Pemaquid on the crown, in a petition urging the home government to bear the cost of this garrison; but the attempt failed ${ }^{6}$. Nevertheless, Phips, writing home in the spring of 1693 , could give a satisfactory account of the colony. The fortifications of Pemaquid had been undertaken and completed, whilst other repairs were going forward; the enemy Indians had had a bad winter, through the destruction of their corn; Phips himself had built a I50-ton yacht to supersede the royal frigate for defence; the people were well satisfied, and would shew their loyalty if another attack on Canada were ordered ${ }^{7}$. It is moreover worthy of note that at the time when Massachusetts asked the crown to bear the cost of the Pemaquid garrison, they could yet afford to make numerous payments to agents and other supporters in England. In 1694, presents were voted, varying in amount from $£_{2} 5$ to $£_{2} 5^{\circ}$, some for duties and expenses of agency, others for offices not specified ${ }^{8}$. The loyalty

1 Usher to the Lords of Trade, C.C. $1689-92,2586$.

2 Usher to the Earl of Nottingham, C.C. I693-6, 40.

${ }^{3}$ C.C. $1689-92,2586$.

- Assembly of New Hampshire to the King and Queen, C.C. $1693-6,250$.

5 Phips to the Earl of Nottingham, ib. 108 .

- Address of Council of Massachusetts to the King and Queen, ib. Ioo.

- Phips to the Lords of Trade, $i b .237$.

Minutes of Massachusetts Assembly, ib. I103. 
of the province, asserted thus buoyantly by Phips, was soon to be put to the test. In February I693, royal intimation was sent to Phips and Fletcher that a squadron of 12 ships would reach New England in May or June from the West Indies, to refit, take reinforcements appointed by New England, and attack Canada. The assembly was urged to have everything ready, and the two governors to consult ${ }^{1}$. In April this letter had not yet arrived.

Meanwhile in New York Fletcher was toiling and grumbling as ever. The two companies, he complained, were under great discouragement, and four would be too few for the requirements of defence. Phips was rather a hindrance than a help, and Pennsylvania would neither fight themselves nor part with money to such as would do it for them ${ }^{2}$. In February a successful expedition against the French and Indians followed the news of an enemy incursion near Senectady. Fletcher himself went with reinforcements, and Ingoldsby took the main command, with the result that after several light conflicts, the enemy beat a general retreat ${ }^{3}$, but were not pursued owing to the backwardness of the English Indians. New York however was highly delighted. 'The like expedition was never seen in the province,' and the Mayor and common council celebrated the occasion by a presentation to the governor ${ }^{4}$. During Fletcher's absence, an appeal for help had been made by the council to the other colonies. Connecticut sent no answer; Pennsylvania good wishes, East Jersey $£ 248$ and a promise of more, thanks largely to the governor, Maryland some bills, two-thirds of which were protested ${ }^{5}$; the other colonies did not answer until too late. Thus Fletcher returned to take up his former rôle. The fort was dropping down; and even the buildings as well; arms were deficient; there were too few men; whilst the 'governor of New England is a machine moved by a fanatical finger, the contempt of wise men, and the sport of fools ${ }^{6}$.' In May Fletcher obtained the satisfaction and the additional anxiety of receiving command of the Connecticut militia in place of Phips ${ }^{7}$.

1 The King to Phips, C.C. $1693-6,48$.

2 Fletcher to Blathwayt, $i b .395$.

4 Address to Fletcher, $i b .48 \mathrm{r}$. ${ }_{5}$ Minutes of New York Council, ib. 274.

"Fletcher to the Earl of Nottingham, ib. $178.7 \mathrm{Ib} .3 \mathrm{IO}$. 


\section{(c) The War in the West Indies}

As in America the War divides naturally into two periods, in the first of which Massachusetts under Phips played the leading part, and in the second, New York under Fletcher; so in the West Indies, the three governments take their turn to focus the importance of the war, partly because the islands are weak and cannot long sustain the strain of leadership. Thus for the first few years, the Leeward Islands under Codrington play the leading part, until, exhausted by their efforts, they hand on the guidance to Barbados, whose governor, James Kendall, is scarcely inferior in ability to Codrington; whilst from 1694 onwards, the interest of a barren war centres mainly in Jamaica, under Sir William Beeston.

\section{The period of Codrington}

The declaration of war was followed by many accounts setting forth the bad condition of defence in the islands, and many proposals by which their strength might be increased. At St Kitts, the only island with a regular garrison, there were two companies of infantry, in extreme want of clothing and pay, the latter nearly six years in $\operatorname{arrears}^{1}$; whilst the fort was not properly equipped, and several soldiers were too old and decrepit for duty ${ }^{2}$. There was moreover great need for ships. Codrington had no frigate to guard the Leeward Islands against 'pilfering pickerooners' ${ }^{3}$; and Stede of Barbados could complain that 'the French continue to do what they please in these islands, and I have no man-of-war to prevent them ${ }^{4}$.' The Irish Catholics were a further source of unrest. Barbados had prevented them gaining political power ${ }^{5}$; but since the offenders were mainly of the class of servants, this restriction did not amount to much ${ }^{6}$. In Montserrat the Irish outnumbered the English settlers by at least two to one, and they had been

1 Deputy-Governor Hill to the Lords of Trade, C.C. I689-92, 4.

2 Ib. 65 .

3 Stede to the Earl of Shrewsbury, $i b$. 155.

Ib. p. xxix.

${ }_{5}$ Minutes of Council of Barbados and Order of Lieutenant-Governor in Council, ih. $34-5$.

${ }_{6}$ Barbados Council to the Prince of Orange, $i b .47$. 
disarmed'. But the chief trouble was in St Kitts, where the proximity of the French greatly increased the danger from revolt.

\section{Fall of St Kitts}

In July I 689 the fears of St Kitts were realized. 'The bloody Papists and Irish assembled suddenly, and declaring themselves for King James, killed, burned and destroyed all that belonged to the Protestant interest ${ }^{2}$,' gaining help, as was natural from their French neighbours; and it was soon evident that the dual occupation of the island created an impossible situation, which came to an end in the same month. The French mustered a fleet of eighteen sail, including six men-of-war, under the Governor of Martinique, anchored at Basseterre on July the I 7 th, and within two hours had forced the English into the fort, and devastated the southern end of the island ${ }^{3}$. The Irish rebels deserted en masse to the French ${ }^{4}$, and on the 22nd the siege of the fort began. 'The French fired 970 odd cannon, and killed us a turkey, a dog, and three horses ${ }^{5}$.' Lieutenant-Governor Hill held out for a fortnight, but was then compelled to surrender, through lack of supplies. His losses were apparently less than those of the besiegers. According to Stede, the Irish would have put all to the sword, but De Blenac, the French commander, would not allow such a massacre ${ }^{6}$. The garrison were allowed to embark for Nevis, where the soldiers at first refused to serve again until their arrears had been paid, but Codrington's influence eventually prevailed?. Meanwhile Barbados had sent 800 men to Antigua, the headquarters of the Leeward Islands, to reinforce St Kitts, but they arrived too late to save that island. The next French attack fell on the small island of Barbuda, and here again the Irish were in evidence, but the attempt failed and nearly resulted in the loss of the

1 C.C. $1689-92$, p. xxix. For distribution of population see Appendix C and references.

2 Stede to the Earl of Shrewsbury, ib. 262.

3 Codrington to the Lords of Trade, $i b .345$.

4 Carpenter and Belchamber to the Commissioners of Customs, ib. $36 \mathrm{r}$.

5 Hill to Netheway, $i b$. 280.

- Stede to the Earl of Shrewsbury, $i b .397$.

7 Codrington to the Lords of Trade, C.C. $1689-92,345$. 
French ships. Nevis now decided to take no more risks with the Irish population, and transported them all to Jamaical. Montserrat followed suit, whilst from Antigua the Irish were also transported 'to those places where they can give us no trouble?'

\section{Difficulty of defence}

With the fall of St Kitts, a general air of uneasiness settled on the islands. Antigua suffered from attacks by the Indians, incited, according to Codrington, by the French; and half the inhabitants were on guard every night ${ }^{3}$. Anguilla, one of the smaller islands, fell and was retaken" 4 'Strange reports of King James' success in Ireland ' were brought to the Leeward Islands by a provision ship, whose master declared that if he had known they were under King William he would have taken his beef to Martinique, and was promptly put under arrest by the vigilant Codrington. Nevis caused trouble by refusing to part with the fugitives from St Kitts, in spite of the governor's orders, and the fact that there was no comfortable living for them in Nevis. Codrington therefore appointed Sir Timothy Thornhill, commander of the Barbados expeditionary force, to command the militia, subdue this insubordination, and send the needy refugees to Antigua. 'Some fancy these colonies are independent states, and attribute to their little assemblies the power and authority of the Parliament of England,' Codrington commented, and recommended their representation in that English Parliament ${ }^{5}$.

In Barbados, Stede offered himself to raise $f_{1} 10,000$ for the prosecution of the war, but the people expected all expenses from that source to be defrayed by the public revenue. They were however loyal and well affected, according to Stede. This island also suffered from French raiding vessels which recently took two Barbados ships before their very eyes ${ }^{6}$. An appeal for help came from Codrington, when he heard of a French

1 Carpenter and Belchamber to the Commissioners of Customs, C.C. I689-92, 36I.

2 Codrington to the Lords of Trade, $i b .444$.

$4 \mathrm{Ib} .444$.

3 Ib. 548 .

6 Stede to the Lords of Trade, $i b .759$.

5 Ib. 548 . 
attack designed on Nevis; but the answer was not such as to satisfy.

It is surprising that Barbados out of 1200 spare arms could only lend us 100 old matchlocks, and out of I 400 barrels of powder could only lend us twenty, and more so that out of 130 ships they could not spare us one ${ }^{1}$.

In 1690 however a new factor appeared in the situation by the arrival of a squadron from England.

\section{Help from England}

The need for sending men-of-war to the West Indies had been early recognized at home; and immediately on the outbreak of war a squadron was destined for that purpose ${ }^{2}$ : In May, more detailed orders were given for eight ships to sail within a few weeks ${ }^{3}$. The usual delays had however arisen; and in November, further orders instructed Captain Wright, commanding the squadron, to take up the Duke of Bolton's regiment, and proceed to the Leeward Islands, putting himself under the orders of Codrington ${ }^{4}$. In May 1690 the fleet arrived at Barbados. The new governor of that island, Colonel James Kendall, arrived with it; and his first dispatch is concerned with the state of the soldiers on board. 'Never was a regiment so carelessly sent out or so extremely neglected;... a hundred odd men were landed very ill....In ten days we clothed the whole regiment, which was naked before ${ }^{5}$ '. Kendall also hurried the fleet on its way, pointing out the need for haste to Wright, who appeared quite content to dally; and on the 26th the fleet sailed for the Leeward Islands. Codrington, welcoming the assistance in high hopes, found that the regiment numbered only 500 men, out of the 930 promised, and proceeded to criticize the stores sent with them. The small arms consisted of matchlocks and firelocks. 'Both...are extraordinarily heavy. Antigua cannot use matchlocks; and the firelocks have bad locks, and are as likely to missfire as not ${ }^{6}$.'

1 Codrington to the Lords of Trade, C.C. $r 689-92,789$.

2 Circular to Governors of Colonies, $i b .69$.

3 List of ships given by the Admiralty, $i b$. 169.

${ }^{5}$ Kendall to the Earl of Shrewsbury, $i b .968$.

${ }^{4} \mathrm{Ib} .609$.

${ }^{6}$ Codrington to the Lords of Trade, $i b .927$. 


\section{Recapture of St Kitts}

However, Codrington decided to make the best of his material, and speedily gained a success. Raising a force of 2500 men he retook St Kitts in June, and shipped away the French inhabitants in their turn to Hispaniola, St Martins, and St Domingo. About the same time St Eustatia, previously captured from the Dutch by France, was recaptured by Thornhill. These campaigns, successful as they were, were a considerable strain on the slender finances of the islands; and Codrington was compelled to support them out of his own purse $^{1}$. He planned on, however, asking help from Jamaica and Barbados for an attack on the larger French islands of Guadeloupe and Martinique. Barbados replied that no help could be spared ${ }^{2}$. Jamaica remained silent ${ }^{3}$. As in the case of the American colonies, the islands bearing the brunt of the war now appealed to the home government for compulsory assistance from their neighbours, who refused to help voluntarily. Ten to twelve hundred men, they claimed, were needed from Barbados ${ }^{4}$. As a result of this the Lords of Trade instructed Kendall to send help as far as possible, even though he could not obtain the council's consent to such assistance ${ }^{5}$; and this order, carried out as it was by the governor, smoothed the way to common action for the remaining campaigns of the war. It was indeed high time that some such arrangement was made. Codrington wrote home in November in a very discontented vein. The men of Nevis refused to stir until the plunder from $\mathrm{S} t$ Kitts was divided. The captains challenged the major for shipping their companies without their consent. The colonel and the lieutenant-colonel disputed the wisdom of the plan, and the soldiers were unwilling to go. 'It is the irrational obstinacy of the common people, fomented by some of the inferior discontented officers.... With the Barbadians the chief

1 C.C. $1689-92$, 1004.

2 Minutes of Barbados Council, $i b .1046$.

3 Codrington to the Lords of Trade, $i b$. I ror.

4 Memorial of merchants trading to the Leeward Islands to the Lords of Trade, $i b$. I I I 1 .

5 Lords of Trade to Kendall and Codrington, ib. II 58, 1207. 
officers are most at fault.' One exception alone did Codrington make to his general denunciation. 'Governor Kendall is a gentleman of such worth, honour, and loyalty that I am sure we shall be in accord in all things ${ }^{1}$ - - no slight tribute this, from one seventeenth century colonial governor to another.

\section{Attack on the French islands}

The year I69I saw the attack on France in the West Indies. Codrington offered in February to organize the expedition against the French islands, if Kendall would send 500 men; or, to send the regiment and as many men as Barbados previously sent, if Kendall preferred to lead the attack. ('He has three times as many men in his one Island, as I have in my four ${ }^{2}$.') Kendall replied that against Martinique he would help as far as he possibly could ${ }^{3}$. In February therefore, the expedition was launched. Codrington landed in Guadeloupe, instead of first making for Martinique, as Kendall appears to have wished, and devastated most of the island. But this was the extent of his success. His preparations for attacking the fort failed, apparently through Captain Wright's action in drawing off the marines. The naval commander also, according to Codrington, allowed the French fleet to escape. 'I was an eyewitness...and never saw such cowardice and treachery in any man as in Captain Wright 4.' The latter was even accused of firing at one of his own ships, as she attempted to pursue the French fleet ${ }^{5}$. Kendall was equally condemnatory of Wright. 'The people here, and in the Leeward Islands are much incensed against him'; and although he refers to the 'preposterous landing in Guadeloupe,' the Governor of Barbados is still preparing to send a regiment to Codrington's assistance. 'Sickness and chance have so decreased our numbers that we can make no further attempt on any French island without English help,' but the addition of three or four hundred men to the fleet would do mischief to the enemy ${ }^{6}$. On the other hand, Sir Timothy

1 Codrington to the Lords of Trade, C.C. I689-92, 1212. 2 Ib. 1319.

3 Kendall to the Lords of Trade, $i b$. ${ }_{13}^{84}$.

4 Codrington to Colonel Bayes, ib. 1546.

5 Codrington to the Lords of Trade, $i b$. 1617.

6 Kendall to the Lords of Trade, $i b$. I621. 
Thornhill blames Codrington for the failure. 'He ran off in distraction at midnight and now charges the Admiral with blame ${ }^{1}$; but as 'Thornhill's previous reputation was not above suspicion, and as he was at this time hoping to succeed Codrington, if the latter was recalled ${ }^{2}$, his evidence may be more than usually partisan.

The strain of these attacks was too much for the thinly-populated Leeward Islands. There was very little money, and trade was mostly 'by truck ${ }^{3}$.' 'There were not as many men in all the islands as in Nevis alone two years before ${ }^{4}$, while this latter island had lost 1500 men by sickness ${ }^{5}$. St Kitts was in a sad state; there was great scarcity of provisions ("the coarsest diet known among us has been welcome to me,' writes LieutenantGovernor Hill). Disease was rife; the companies seven years in arrears for pay; the fort as before 'too slenderly equipped with stores of any kind.' The people had no money and were consumed by much sickness ${ }^{6}$. And so Codrington could write in July 1691: 'The Leeward Islands are worn out.....The Governor of Barbados is the fittest to command all future expeditions. He has force sufficient to do great things?'

One great lesson Codrington had learnt from his two years' experience, a lesson too easily forgotten in West Indian wars:

All turns upon mastery of the sea. If we have it, our islands are safe, however thinly peopled; if the French have it, we cannot, after the recent mortality, raise men enough in all the islands to hold one of them ${ }^{8}$.

\section{Wheler's squadron}

In the West Indies, as in America, I692 was a year of waiting. The Leeward Islands having decided that they could no longer take the offensive, the next move in the game came from home, by the despatch of a fleet under Sir Charles Wheler. The squadron commanded by Captain Wright, first ordered to return

1 Sir Timothy Thornhill to the Earl of Nottingham, C.C. $I 689-92$, I630.

2 Kendall to the Earl of Nottingham, ib. 1623.

3 Codrington to the Lords of Trade, $i b$. 1643 .

Ib. 1644 .

6 Hill to the Lords of Trade, $i b$. 1284.

5 Ib. 1320.

7 Codrington to the Lords of Trade, $i b$. 1644.

8 Codrington to the Lord President, $i b .1756$. 
to England in the autumn of 1690 , had been retained by royal permission, first till the following January, then till further orders; and under Captain Wrenn, who succeeded the incompetent Wright, was still among the islands in $1692^{1}$; but the arrival of a larger fleet under Wheler was the event to which the colonists looked forward for the relief of their position ${ }^{2}$. Barbados was still in harmony with the Leeward Islands, and together they did what was possible to strengthen the fleet in the meantime ${ }^{3}$. Kendall was however not satisfied with the defences of his own government. Sickness was on board the ships, and the soldiers much reduced. The extent of the mortality is shewn by the fact that of the 800 men sent to the Leeward Islands originally for the reinforcement of St Kitts 100 only had returned, whilst further reductions were caused by the merchant ships, who were able to recruit their own strength from the worse paid crews of the men-of-war ${ }^{4}$. De Blenac, on the other hand had received considerable reinforcements at Martinique, so that the Leeward Islands would seem to be threatened ${ }^{5}$. Kendall's greatest fear however was of the negroes. As for the French they were being resisted at sea with some success. The Governor of Barbados, relating how his frigate had chased and put to flight the enemy Mary Rose, was prompted in pride to remark: 'No doubt de Blenac takes me for a very well-bred man; for his ships are no sooner seen on the coast than I send immediately to compliment them ${ }^{6}$.' In the Leeward Islands, Codrington, busy in reorganizing the reduced forces under his control, has much to complain of. The soldiers in St Kitts were almost naked; and there was nothing to be procured there as garb a soldier ought to appear in ?. The 'Blues'the Duke of Bolton's regiment-had received a consignment of clothing which as usual Codrington found it necessary to criticize. It is 'extremely good, but too heavy for the climate ${ }^{8}$.'

1 Minutes of the Council of War at Barbados, C.C. I689-92, 2025.

2 Codrington to the Lords of Trade, $i b$. 1993.

3 Minutes of the Council of War at Barbados, ib. 2024-5.

4 Representation by the Agents of Barbados, ib. 2449.

5 Kendall to the Lords of Trade, ib. 21 10.

6 Kendall to Blathwayt, $i b .2621$.

7 Hill to the Lords of Trade, $i b .2421$.

8 Codrington to the Agents for the Leeward Islands, $i b .2401$. 
This simple complaint has behind it the main cause of wars and revolutions and all the tragedies of history-lack of understanding. Thus it was with England and her colonies.

In February the long expected squadron arrived at Barbados, and was royally entertained by Kendall, who joined 900 men to the expedition ${ }^{1}$. Intelligence was sent to Codrington and arrangements made for a junction of forces off Martinique, the goal of the first attack ${ }^{2}$. After considerable discussion, it was decided to employ the Irish of Barbados, in consideration of their good conduct ${ }^{3}$; whilst another detail, also significant for the spirit of the times, was the appointment of an officer in charge of plunder ${ }^{4}$. After three months expectation and preparation, the great expedition sailed for Martinique. A council of war was held before St Pierre, and with amazing suddenness the whole scheme fizzled out; for there, a majority decided for withdrawal ${ }^{5}$, to the indignation of Kendall, and the consternation of Barbados ${ }^{6}$. Codrington had accompanied the detachment from the Leeward Islands, not in any official position but as an ordinary volunteer to encourage his men, who depended so much upon his presence, and he has given the reasons for this surprising failure? The time of arrival he believed to be unfortunate, for great rains fell in May, and these were fatal to an army in the field; whilst the actual time allowed was too short. As it was, Wheler left the West Indies as late as he possibly could in accordance with his instructions. The French were given warning some time before the time planned, and were able to fortify; and finally, the forces from Europe were not strong enough. Thus at least three of the main causes of failure were due directly to neglect by the home authorities to lay their plans in accordance with the more obvious peculiarities and the more pressing needs of a West Indian campaign. Codrington concluded his dispatch by again insisting that the islands were incapable of defence, individually or collectively;

1 Kendall to the Earl of Nottingham, C.C. $1693-6,164$.

2 Wheler to Nottingham, ib. I70, 194.

3 Minutes of the Council of War in the West Indies, $i b .204$.

* Ib. 200 .

5 Ib. $28 \mathrm{r}$.

- Kendall to the Earl of Nottingham, ib. 334.

7 Codrington to the Lords of Trade, $i b .336$. 
that England must always have a sea force there, and if possible a land army too. The ill-fated expedition had lost 800 men before Martinique, and had been further depleted by disease, communicated from the merchantships lying off Barbados ${ }^{1}$, the extent of which losses appeared when the fleet arrived at Boston to carry out the second of its duties. Thus ended the English offensive in the West Indies. From this time, the war was purely defensive, here and in America.

\section{The prominence of Famaica}

In the third period of the West Indian war, an indefinite and otherwise uninteresting period, Jamaica comes into prominence. Hitherto, while the Leeward Islands and Barbados were struggling to defeat the French, Jamaica had not played a notable part; but in I 694 a change came, and England's latest acquisition in the West Indies focussed the importance of the war for its remaining three years. The island first came into prominence in 1692 , through the great earthquake of May-an event great enough to startle Macaulay into introducing the West Indies for the first and last time into his history of the Revolution. The description of this catastrophe could hardly but be dramatic.

In ten minutes it threw down all churches, dwelling houses and sugar-works in the Island. Two-thirds of Port Royal was swallowed up by the sea, all the forts and fortifications demolished, and great part of the inhabitants miserably knocked on the head or drowned.

One of the men-of-war was sucked under and ruined; and to crown the calamity, a French landing party arrived to take advantage of the island's misfortune. The settlers however stood to their guns, and captured or killed all but eighteen of the party, while the remaining frigate and a sloop tackled and burned the conveying ships ${ }^{2}$. At home the distress of Jamaica was realized, but the Queen appealed to the people in spite of it to join in the great expedition under Wheler the following spring. The island replied that that was impossible, but that they would do their best meanwhile to harass the enemy ${ }^{3}$.

1 Codrington to the Lords of Trade, C.C. $1693-6,347$.

2 President and Council of Jamaica to the Lords of Trade, $i b, 2278$.

3 Correspondence between Jamaica and the Queen, $i b .2457,27$ I 5 . 


\section{French attack Famaica}

In a memorandum surviving from the Governor of Martinique $^{1}$ plans are given for a French attack on Jamaica in $\mathbf{r} 693$. The idea seemed to be that of settling the various fugitive French from the weak islands, especially St Kitts, in Jamaica, conducting the enterprise with five or six men-of-war and 2000 regular troops, who would sail under the English flag with a commission from James, and a proclamation of him as king. In a letter of almost the same date, Codrington gave warning of the danger ${ }^{2}$, but for nearly a year all was quiet, except for the usual landing of French pickeroons, stealing negroes and property ${ }^{3}$. In May I694 however, the attack was launched. An English merchant-skipper escaped with two companions from captivity at Petit Guavos, and with remarkable courage crossed to Jamaica in a small canoe, giving warning of the impending attack $^{4}$. Beeston, now lieutenant-governor, immediately drew in the straggling population behind the fortifications ${ }^{5}$. On the $17^{\text {th }}$, the French landed in Cow Bay, and proceeded to devastate the island. Beeston, seeing that he would be hemmed in, appealed for a relieving force of at least six men-of-war, for the French, having gained command of the sea, would plunder all the outlying parts. He was right. For a month the French carried on their work of destruction.

Some of the straggling people that were left behind they tortured, and in particular two they murdered in cold blood, some women they suffered the negroes to violate, some they dug out of their graves, so that more inhuman barbarities were never committed by Turk or infidel ${ }^{6}$.

The people of Jamaica held out however, and, after nearly six weeks of this ravaging, with occasional sharp assaults, succeeded in inflicting on the enemy a repulse which, though not in itself crushing, was yet enough for the plundering army of invaders; and on the 18 th of July they re-embarked, leaving behind them

1 C.C. $1693-6,433$.

2 Codrington to the Lords of Trade, $i b .437$

3 Beeston to the Earl of Nottingham, ib. 634 .

4 Minutes of the Jamaica Council, $i b$. 1074.

6 Beeston to Shrewsbury, ib. 1236.

5 Ib. 1083 . 
fifty sugar-works in ruins, and every living thing destroyed that they had met with on the plantations ${ }^{1}$. At last the home government realized that a strong force must be sent to the West Indies, not a mere handful of recruits; and orders were given for the despatch of two regiments entire to Jamaica ${ }^{2}$; whilst preparations were made for an English expedition to attack Hispaniola ${ }^{3}$.

\section{Wilmot's expedition}

The evidence about this expedition of 1695 is not perfect, but certain facts clearly emerge. In the first place, it sailed too late. Planned for October I694, delays caused by Admiralty, Navy Board, Ordnance Office, Victualling Board, and Commissioner of Transport, postponed the actual departure until January ${ }^{4}$. The attack on the French islands was to receive the assistance of the Spanish governor of San Domingo; but relations with Spain were apt to be unfriendly throughout this period $^{5}$, and there was a lack of harmony in this alliance ${ }^{6}$. The command of the sea forces was given to Admiral Wilmot, and that of the troops to Colonel Lillingston; and though both were placed under the orders of Beeston, this was not enough to prevent those fatal quarrels, which almost invariably resulted from such divided command. In spite of the fact that, according to Lillingston, the King especially urged them to work harmoniously, there were from the beginning continual disagreements, probably due more to Wilmot than to Lillingston ${ }^{7}$. The attack on Hispaniola failed, and in August the fleet arrived at Jamaica. Lillingston's regiment, which formerly numbered about 1300 , could now barely raise 300 , of which the private soldiers accounted for little more than half ${ }^{8}$. Such was the result of a divided command, and a frantic rush for plunder, the sailors achieving the greater notoriety in this respect ${ }^{9}$. 'The

1 Beeston to the Lords of Trade and to Sir John Trenchard,C.C. 1693-6, I $194-5$.

2 Blathwayt to Trenchard, $i b .1277$.

3 Instructions to Beeston, Lillingston and Wilmot, $i b .1618-20$.

${ }^{4} \mathrm{Ib} .1572,1574$.

5 Sir Nathaniel Johnson to the Lords of Trade, C.C. $1689-92,83$. Beeston to Shrewsbury, C.C. $1696-7,163$.

${ }^{6}$ Wilmot to Blathwayt and Lillingston to the Marquis of Normanby, C.C. $1693-6,1980,2021$.

8 Ib. 2123 .

7 Beeston's Account, ib. 2022.

9 Lillingston to Normanby, ib. $202 \mathrm{I}$. 
Commander-in-Chief was charged with regarding his own private interest, that he encouraged his seamen on all occasions to act as pirates, a disgrace to Englishmen'; whilst Commodore Wilmot, who died on the homeward voyage, left $f_{6000}$ in effects on board his own ship; and this treasure engaged his family in a long suit at law with another officer of the expedition $^{1}$. Apart from this greed for plunder, division of authority was, throughout, the curse of West Indian war policy, not only between rival commanders, but between commander and governor.

If the governor offers to interpose, even the captain of a fireship (a poor fellow perhaps not taken half a year from before the mast) will write him such a hectoring, saucy letter that a man would throw up his command, rather than carry such insignificant marks of authority ${ }^{2}$.

\section{Distress of Famaica}

Jamaica was by this time in worse plight than ever. The muster rolls in 1696 shewed a decline in one year from $244^{\circ}$ to $1390^{3}$. Men were leaving in large numbers, partly through the French depredations, partly owing to the practice of pressing for man-of-war and merchant-ship crews. Also 'there came not from England necessaries enough to furnish the people's wants, nor ships large enough to take away their produce ${ }^{4}$.' No stores or provisions had arrived for the frigate although it had been stationed there for two years ${ }^{5}$.

Our privateers, seamen, and all our ordinary people are gone... this owing chiefly to men-of-war pressing continually; the fear of the French has carried away others, and many die by their coming here at this time of the year (October) ${ }^{6} \ldots$.. The sailors newly come are many of them dead; by continuing to arrive in the hot and sickly months?

By January 1697 , however, the island was in perfect health; but its trade continued to suffer severely. Most of the ships were taken, either coming or returning to the vast cost of

1 Barrow, Naval Hist. of Great Britain, I1, p. 308 et seq.

2 Gilbert Heathcote to James Vernon, C.C. I693-6, 2329.

3 Minutes of the Jamaica Council, C.C. $1696-7,97$.

4 Beeston to the Board of Trade, ib. 130.

6 Beeston to Shrewsbury, ib. 232.

5 Ib. rox.

7b. 323 . 
merchants and inhabitants ${ }^{1}$; and the treasury was nearly $£ 5000$ in debt, owing to the war ${ }^{2}$.

\section{The condition of the islands}

The other West Indian islands contain little of importance in the last years of the war. The state of defence in Bermuda was brought to the notice of the King in 1696 by the Board of Trade; and an engineer was ordered to go from home to organize fortification there ${ }^{3}$. Apart from this, the English government interfered little in the lesser islands. In August I693, Kendall gave up the governorship of Barbados, amid many compliments from that island; and, while grievances were inevitably claimed under his rule, the smallness of the list, and the nature of the charges themselves, revert rather to the governor's credit than otherwise.

He compelled every man (except Councillors) to serve in some troop or company, and not to leave it without the Captain's permission. He imposed an oath of obedience to himself on all officers, on penalty of death. He suspended a councillor for refusing to cut down a wood on ground required for fortifications ${ }^{4}$.

Kendall is accused, in short, of depriving his subjects of some of their cherished independence, in order that the island may make a good show in defence. Barbados, shortly after, asked for a regiment to be stationed there, and the King inclined to grant this; whereupon the agents submitted that the island was too poor to bear the charge of transportation, or of free quarterage, chiefly owing to the $£ 30$,000 which was lost on the Martinique expedition; and they further suggested, as they continued to do at every opportunity, that the $4 \frac{1}{2}$ per cent. export duty should be used for this purpose ${ }^{5}$. The King however proposed a compromise. He would grant quarterage, if Barbados would bear the cost of transport. The agents, thanking the King for the first part of his proposal, threw themselves on the royal mercy for the rest ${ }^{6}$.

In the Leeward Islands, the royal troops were in an un-

1 Beeston to the Board of Trade, C.C. $1696-7,639 . \quad 2$ Ib. 1318.

3 Board of Trade to the King and Order in Council, ib. 487-8.

4 Grievances of Barbados against Kendall, C.C. $1693-6,656$.

s Memorial of Agents for Barbados, $i b .759$.

6 $I b .916$. 
happy condition. Three-quarters of the regiment had perished, through war and disease, and their pay had not been cleared since I692 (this is November I694); whilst the officers were being given tallies payable three years from date, at 5 per cent. loss. The Lords of Trade therefore recommended 400 recruits for the government ${ }^{1}$. Upon this, the agents for the Leeward Islands scored at the expense of Barbados, by a piece of sharp practice. They succeeded in having the Barbados reinforcements, five companies of 100 men each, sent by way of the Leeward Islands, whence Russell, Kendall's successor in Barbados, was ordered to take them after two months, if they were not further required ${ }^{2}$. Thus when the regiment finally reached Barbados, it had lost half its numbers by death and desertion ${ }^{3}$. Russell carried on Kendall's policy, however, refusing relaxation in spite of obstacles ${ }^{4}$, but died in 1696 ; and the government reverted to one Bond, 'an aged and crazy man ${ }^{5}$,' not likely to disturb the uneventful course of affairs.

\section{Nevill's expedition}

The only remaining item of importance in the West Indies was the expedition under Admiral Nevill. An attack had been feared on Jamaica from a considerable French fleet, but it later appeared that this fleet was bound for Spanish treasure at Portobello $^{6}$. A squadron was sent out under Nevill, chiefly to counter this threat but also to convoy merchantships sailing to the West Indies at this time; and arrived on the scene of action in April $1697^{7}$. Meanwhile, the French fleet passed the Leeward Islands ${ }^{8}$, and Barbados, where there were not seven rounds of powder in the fort ${ }^{9}$; and passed on to Petit Guavos. Nevill arrived ten days too late. He was outsailed by the French fleet returning with its treasure of captured Spanish plate; and took

1 Minute of the Lords of Trade, C.C. $1693-6,1523$, 537.

${ }^{2}$ The King to Russell, ib. 1798 .

${ }^{3}$ Russell to the Board of Trade and to Shrewsbury, C.C. I696-7, ro4-5.

4 Minutes of the Council of Barbados, $i b .49$.

5 Ib. 132, 193. ${ }^{6}$ Beeston to Blathwayt, ib. 868.

- President and Council of Barbados to the Board of Trade, ib. 978.

8 Codrington to the Board of Trade, $i b .990$.

4 Schomburgk, Hist. of Barbados, p. 307. 
only one ship, which proved to be worth $f_{20,000^{1}}$. No sooner was Nevill gone, than the French privateers returned, 'knowing,' as Codrington said, 'that I have but one bad sailing frigate, they insult us daily 2.' Thus ends the last of the four futile expeditions to the West Indies. Of these, two had arrived at the wrong time, too late or with too short time for success; a third had failed, partly by reason of an incompetent commander, partly through divided command; and the fourth had combined all these faults ${ }^{3}$. Thus the Peace of Ryswick proclaimed in October $\times 697$, descended on islands wearied by war and devastated by sickness. They could however claim, that in spite of infirmities, no ground had been lost.

\section{(d) Defence in America 1693-7}

\section{Wheler's squadron in Boston}

In June 1693 , Admiral Wheler, having failed in the West Indies, arrived with his fleet at Boston. Sickness had spread on board, so that Massachusetts found it necessary to forbid all intercourse with her people; while Phips made arrangements for the care of the sailors ${ }^{4}$. The following month, Wheler sent home a dispatch in which he stated that in reply to his proposals for attack, the governor answered that no instructions had yet arrived and therefore no preparation had been made for an expedition against Canada. The force required Phips estimated at 4000 at least, and it should sail not later than the Ist of July, whilst at least four months would be required to obtain help from other colonies. Moreover, there were by this time but 650 men left from the two regiments sent from home; whilst not half the complement of the fleet was fit for duty, and of this half only one-third were seamen. The ships themselves were in good order, and provisions plentiful. Wheler therefore consulted Phips on the question of an isolated attack on Quebec or elsewhere ${ }^{5}$. The governor in reply dissuaded any

1 Beeston to Blathwayt, C.C. I696-7, 1080.

2 Ib. 1148 .

3 Wheler's, Nevill's, Wright's and Wilmot's respectively.

4 Minutes of the Massachusetts Assembly, C.C. 1693-6, 410.

5 Wheler to Phips, ib. 44r. 
attack on Canada, and suggested Newfoundland as the only place worthy of an expedition. For Quebec, it was useless to attack with less than 4000 men $^{1}$. The admiral considered the proposal, and asked Phips for the assistance of 400 men. Phips replied that he could not allow them to be marched out of the colony without the assembly's permission; and the assembly had been dissolved on the $5^{\text {th }}$ of the month-that is, after Phips' suggestion of an attack on Newfoundland. He also reminded Wheler that men were needed for an expedition against the Indians, and that sickness on board was dissuading recruits for the navy ${ }^{2}$.

Fletcher, on the other hand, hearing of Wheler's arrival, sent one of his council to welcome the fleet, and to ascertain if he intended to attack Canada, that there might be time to make preparations ${ }^{3}$. This messenger met with so violent a reception from the Boston governor that one of the councillors felt in duty bound to excuse him: 'Sir, you must pardon him his dog-days; he cannot help it ${ }^{4}$.' In September, Wheler's fleet, having no prospect of being able to accomplish anything, sailed for home. A few days previous, Phips had received a letter from William Blathwayt, the secretary to the Council of Trade, mentioning the proposed attack; but the King's orders of February did not reach him until several days later ${ }^{5}$. Thus failed the only attempt to assist the colonies from home in an offensive movement.

Of the land defences in Massachusetts Phips sent a good account. The Indians on the frontier had asked for an everlasting peace, and Massachusetts was therefore now better able to help the neighbouring colonies ${ }^{6}$. Thus wrote the governor. The opportunity came very soon, but within a week of his previous letter, Phips was refusing help to New York, pro-

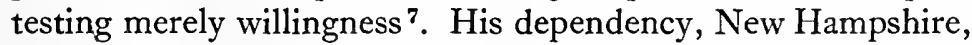
was still in an unsettled state. Boston had withdrawn its garrison of 60 men, and, with Connecticut and Rhode Island, refused

1 Phips to Wheler, C.C. $x 693-6,452$.

3 Minutes of the New York Council, ib. 460.

- Chidley Brooke to Fletcher, $i b .486$.

5 Phips to the Lords of Trade, $i b .578$.

6 Phips to Nottingham, ib. 545.

2 Phips to Wheler, $i b .475$.

7 Phips to Fletcher, ib. 570. 
to help any further. Usher had received and mounted some great guns sent from England, but was in urgent need of men; and suggested, as a remedy for such a situation, the appointment of a general governor over the New England colonies ${ }^{1}$.

\section{Fletcher's attempts at organization}

Meanwhile Fletcher was vainly attempting to organize defence $^{2}$. Frontenac had received fresh stores and men; and the French were outbidding the English in presents to the Indians. Up to this time, they had not prevailed; but Fletcher was much afraid of the influence of French Jesuit missionaries among them. In one case, he offered to take a Jesuit priest, a prisoner of the Indians, in exchange for a 'pretty Indian boy'; but he was not sanguine of the position in general, and feared that unless an expedition went against Canada the Indians would be lost ${ }^{3}$. He could also lament the naval defences of New York, still entrusted to the much-blamed frigate, the Aldborough, 'a dull sailor.' As for cooperation with other colonies, Fletcher found that they would pay no attention to the Queen's letter. Pennsylvania was unwilling even to grant revenue for its own expenses, much less to help New York ${ }^{4}$. The inhabitants 'deny the carnal sword, now will they dip their money in blood.' Fletcher however succeeded in fixing a meeting of commissioners; but when the time came Phips refused to send, and none came from Pennsylvania or Maryland. Thanks to the influence of Andros, a Virginian delegate arrived; but those commissioners who were present refused to settle anything in the absence of such important representation. Fletcher also visited Connecticut to obtain help from there under his commission; but found little encouragement.

They have separated from the Crown of England, not only from the Church, and allow no appeals from their courts, saying that not being permitted to vote for Members of Parliament they are not liable to their laws.... They refuse obedience to my commission, desire a suit at law, and will submit to a Quo Warranto.

1 Usher to the Earl of Nottingham, C.C. $1693-6,454$.

2 Fletcher to Nottingham and to the Lords of Trade; Minutes of the New York Council, ib. 610-3.

3 Fletcher to the Lords of the Treasury, $i b .502$.

4 Fletcher to Blathwayt, ib. 500-I. 
The gentlemen of Connecticut too were wont to make much boast of their independence under the Charter; and Fletcher did not improve matters by kicking one of them downstairs ${ }^{1}$. In Virginia, the House of Burgesses considered that Albany was no bulwark to their state, which was so much burdened by its own defence that they would spare no help to New York ${ }^{2}$. 'We are quite as much opposed to attempts of French and Indians ${ }^{3}$.' Orders came from home in 1693 that Virginia and Maryland should send $£ 500$ and $£^{2} 5^{\circ}$ respectively to New York; but the two states interpreted this retrospectively and counted former gifts of $£ 600$ and $£ 300$ as the required assistance ${ }^{4}$. In the case of Maryland, which frequently sent bills that were protested ${ }^{5}$, this gift may have been worth very little. In addition to these refusals of help, Fletcher had further grounds of complaint against New Jersey, Connecticut and Pennsylvania, that by evading the payment of duties there they were inducing the inhabitants of New York to migrate thither ${ }^{6}$.

As the war progressed, the position of the Indians, on whom so much depended, became more and more uncertain. In July 1694 they were negotiating with Frontenac, asking for neutrality, which Fletcher feared the French would not allow, insisting on a full alliance. Frontenac was now receiving annual supplies from home, and threatened to lead in person an attack against Albany ${ }^{7}$. In June a massacre of English by French Indians took place at Oyster River, which stroke was considered to be of great advantage for the French because it broke off all talk of peace between English and French Indians ${ }^{8}$. By September however, the English Indians had been induced to sign treaties with the French as well as the English ${ }^{9}$.

In August 1694 , instructions from England fixed the actual quotas to be sent by colonies for the defence of New YorkMassachusetts $35^{\circ}$ men, Virginia 240 , and others in proportion ${ }^{10}$.

1 C.C. ${ }^{6} 693-6,6$ 10-3, 649-5o.

2 Journal of Virginian House of Burgesses, ib. 664.

3 Ralph Wormeley to the Earl of Nottingham, ib. 794.

Ib.6ro-3. ${ }_{5}$ Minutes of the New York Council, ib. 775.

- Fletcher to Blathwayt, ib. 500.

7 Fletcher to the Lords of Trade, $i b$. 829.

$8 \mathrm{Ib} . \mathrm{I}_{153}, \mathrm{I}_{55}$. Also Parkman, op. cit., pp. 383 et seq.

9 Fletcher to Trenchard, $i b$. 1340. Also $i b$. Chap. xvilI.

10 Minutes of the Lords of Trade, $i b$. 1176. 
A loophole for evasion was however given by the clause instructing the governor to take no greater quota from any colony than the proportion he demanded from other colonies ${ }^{1}$. Thus the recalcitrance of one colony could and did endanger the whole scheme. Massachusetts in October declared themselves compelled to keep their men at home because of Indian raids to eastward ${ }^{2}$. This refusal could no longer be attributed to Phips, for that blustering official had been recalled in the early part of the year, to answer charges against him ${ }^{3}$. No improvement was yet seen in New Hampshire, which would not vote money to finish fortifications begun.

'The meaning is,' Usher explained, 'that if the King will keep New Hampshire as a separate province he must do it out of his own exchequer....Let the King appoint a governor, and if they do not kill him outright, they will starve him to death before they give one penny to his subsistence ${ }^{4}$ '

In November 1694 , Fletcher wrote home in good spirits, saying that Albany was in better condition than ever before; and that the Five Nations, in spite of Frontenac's hard pressure, refused to fight against England ${ }^{5}$. Thus 1695 was a quiet year; and the correspondence largely concerned with the quotas of men recently decided upon for New York. Virginia refused to send men, on the ground of poverty and the likeliness of Indian inroads $^{6}$; but sent $£ 500$ instead ${ }^{7}$. In July the Virginians promised to send the quota fixed, on request from New York ${ }^{8}$, but in December they again declined the duty, and asked permission from England to be excused ${ }^{9}$. The King therefore ordered the present of money to be accepted as substitute ${ }^{10}$; and granted the same relaxation to Maryland ${ }^{11}$, whose government had sent $£ 200$ in bills, saying that 'the vast charge which already lies on us ' prevented further assistance, and moreover that New

1 The Queen to the Governor of Rhode Island, C.C. $1693-6,1248$.

2 Address of Massachusetts to the King and Queen, $i b$. 1466.

3 Minutes of the Lords of Trade; and the King to Phips, ib. 862, 879.

4 Usher to the Lords of Trade, $i b$. I I 9 .

5 Fletcher to the Lords of Trade, $i b$. 1518.

${ }_{6}$ Minutes of the Virginian Assembly, $i b$. 179r.

7 Journal of the Virginian House of Burgesses, $i b .1805$.

8 Ib. 1975 .

10 The King to Andros, $i b .2226$.

9 Ib. 2220.

11 The King to Fletcher, $i b .2228$. 
York was no defence to them ${ }^{1}$. They vaguely promised assistance of men when need should require, but with Virginia gained exemption. Connecticut also attempted to evade the burden, and after a long correspondence decided not to send until the other colonies did $\mathrm{so}^{2}$.

Fletcher had moreover difficulty in his own province of New York. The assembly refused to grant the sums he considered necessary for defence and were accordingly prorogued ${ }^{3}$; whilst the old Leislerite faction had gained serious strength by the charges preferred against the governor through Delanoy, a disciple of Jacob Leisler. This accuser made serious allegations of illegal proceedings, and suggested Fletcher's recall, followed by the appointment of a general governor over the whole of Andros' former territory ${ }^{4}$. Fletcher however does not appear greatly disturbed by these difficulties. Addressing his new assembly in April I696, he declared that 'the supplies sent by the King of men, guns and stores, and the orders to the colonies if obeyed will enable us to withstand all our enemies and live in happy security ${ }^{5}$.' He therefore asked for a generous grant, and the appointment of a committee to supervise its use; but as usual was compelled to accept less than he demanded; whilst the quotas were still objected to. Connecticut complained that Fletcher had required its full proportion, while not taking the fixed numbers from other colonies ${ }^{6}$. They next stipulated for only four months service and other special conditions which Fletcher refused ${ }^{7}$. According to their own account however, Connecticut did help New York on occasion with men and money ${ }^{8}$. Pennsylvania and Rhode Island refused to send assistance ${ }^{9}$. Virginia could spare no men, but protested its loyalty with a present of $\oint_{1000^{10}}$. Maryland again petitioned the King for exemption, and awaited his answer before acting ${ }^{\mathbf{1 1}}$,

1 Correspondence between the Governors of New York and Connecticut, C.C. ${ }^{6} 693^{-6}, 2054$.

\footnotetext{
${ }_{2} I b .2054$. 3 Minutes of the Council of New York, ib. I760, 1769.

4 Ib. I892. 5 Minutes of the New York Council, ib. 2315.

6 Order of the King in Council, ib. 2343.

- Fletcher to the Board of Trade, C.C. I696-7, 25-7.

${ }^{8}$ Reasons offered by Major-General Winthrop, $i b .203$.

${ }^{9}$ Fletcher to Blathwayt, ib. I4.

10 Minutes of the Council of Virginia, C.C. $1693-6,2357$.

11 Journal of Maryland House of Burgesses, ib. 2362.
} 
in spite of Governor Nicholson's offer to advance the money himself: "As we have already paid more than $f_{1} 30$ more than the contribution required, we are under no obligation.' Thus Fletcher was obliged to resort to other expedients for defence, the more since the royal forces, increased from two to four companies in 1695 , were much weakened. He therefore adopted the system of one-year recruiting with the inducements of special levy-money and an addition of $4 d$. a day to the King's pay ${ }^{1}$. By prompt action he succeeded in preventing a threatened French inroad in August; he set out for Albany, and rumours of an immense army led by him reached the enemy, who wasted no time in retreating ${ }^{2}$. The Indians on both sides were busy the while. 'They lie in wait on the frontier to kill or take any naked man, woman or child;... Our Indians act the same part with greater success in the French plantations ${ }^{3}$.' The state of unrest among the English forces is shewn by the fact that in May at Senectady the whole guard except one (I 6 men) deserted; and when pursued, five of these resisted until they were killed. Of the remainder taken and court-martialled one only was shot 'owing to the shortage of men 4.' The New York agents claimed that their province had raised $£ 30,000$ for defence, whilst the other colonies between them had contributed but $£ 3000$; and suggested an active policy, either by an attack on Canada to root out the enemy, or at least by grant of $£_{1000}$ for presents to Indians, a garrison of rooo men on the frontier, and stone fortifications, with yearly supplies of stores ${ }^{5}$. Fletcher also asked for similar measures, and for a quick sailing frigate to supersede the present man-of-war. In October 1696 he had not received the stores required for 1695 ; whilst the French were receiving regular annual supplies. Albany was uneasy. Many of the inhabitants intended moving in a body to New York unless an aggressive policy was followed; and the Indians also were pressing for action, and would join if the other colonies combined for attack ${ }^{6}$.

1 Courtlandt to Blathwayt and Fletcher to Shrewsbury, C.C. $1696-7,12,13$.

2 Fletcher to the Board of Trade, $i b .159 .{ }^{3}$ Fletcher to Blathwayt, $i b$. I4.

4 Fletcher to the Board of Trade, $i b .25-7$.

6 New York Agents to the Board of Trade, ib. 194.

- Fletcher to the Board of Trade, ib. 370. 
Throughout the rest of the mainland states, various expedients were necessary to defend the various colonies. Maryland organized the Indians on the frontier by placing them all under the Emperor of Piscattaway, and garrisoned the Potomac strongly ${ }^{\mathbf{1}}$. Even Pennsylvania took steps to confirm the friendship of its neighbouring Indians ${ }^{2}$. The governor of New Jersey was enticing young men to enlist by appointing the favourite captains as recruiters. He wrote to Fletcher:

I am ashamed and grieved that they are so awkward. They still object the exemption or non-compliance of the neighbouring colonies, nor will this ever be remedied unless the support of the frontiers reaches all North America. As it is, the remoter colonies are so many asylums ${ }^{3}$.

New Jersey youths were deserting to the southern colonies, and the governor could with difficulty wring promises from the male population to march to the frontier in case of attack. New Hampshire refused to support its garrisons. 'If the King does. not send early next spring roo men for the place, I believe the French will be masters of it,' said Usher ${ }^{4}$.

\section{Massachusetts appeals for help}

In Massachusetts, the strong independent colony, the climax was reached in this year. Early in the year they had been driven to expedients to encourage the formation of companies for defence, and were offering head-money for captured Indians ${ }^{5}$. They arranged expeditions on a small scale ${ }^{6}$, and spent considerable sums on hired ships to strengthen the naval defences?. In September they were 'in a very poor and distressed condition,....in danger unless a supply of warlike stores and ships of war of greater strength are sent ${ }^{8}$.' And finally in December I696, the proud colony came to Canossa:

For a long time past we have languished under a wasting war, whereby our estates have been much destroyed, and many among

1 Journal of Maryland Burgesses, C.C. $1696-7,67$.

2 Minute of Governor Markham, ib. 92.

3 Governor Hamilton to Fletcher, ib. 56, 174.

4 Usher to the Board of Trade, $i b .282$.

5 Minutes of the Massachusetts Assembly, ib. 41.

6 Ib. 62 .

Ib. 170.

8 Secretary of Massachusetts to Blathwayt, $i b .243$. 
us captured or destroyed....The charge of war has lain heavy on this province, Connecticut having contributed little, and Rhode Island and New Hampshire nothing at all,...but having drawn a considerable charge on us for their defence. We therefore implore your royal aid, humbly praying that the several governments may be jointly concerned in the prosecution of the war, and in supporting the charge thereof... with a garrison of soldiers at the charge of Your Majesty's exchequer,...that you will take into consideration the reduction of Canada, the unhappy fountain from which issue all our miseries.... Thus in humble dependence on your favourable answer for the rescuing of a languishing province and preserving alive a people entirely devoted to your service, we prostrate ourselves at your feet.

This is the petition of Massachusetts to the King, signed not by a royal governor but by William Stoughton, one of the Revolutionary Council who overturned Andros' rule, and by the council appointed, under the new charter, by the colony itself 1 .

The Peace of Ryswick came quietly in America. Rhode Island followed the example of Massachusetts and appealed to the King, as unable to bear the burden of its own defence 2 . The latter colony in spite of its newly-found humility, appears to have been the best in strength of defences ${ }^{3}$. The Maryland militia was suffering from extreme poverty, and scarcity of arms and ammunition ${ }^{4}$. In New York, the four companies were much reduced; and 30 per cent. was being deducted from their pay to compensate for the nominal difference between English and New York monies, regardless of the difference in cost of living. 'The officers can hardly live....and the soldiers have not pay enough to fill their bellies, which makes them very apt to desert'; and they had received hardly any clothing for five years ${ }^{5}$. Moreover, the Five Nations were still wavering. Fletcher did his best to confirm them in the English alliance, with his usual perception; entertaining the principal men, and driving them round New York magnificently in coach and six $^{6}$. Fletcher, however, had

1 Address of Lieutenant-Governor and Council of Massachusetts to the King, C.C. $1696-7,483$.

2 Minutes of the Massachusetts Council etc., $i b$. (1001, I2 17), 1219.

3 Governor of Rhode Island to the King, $i b$. 1037.

4 Nicholson to the Board of Trade, $i b$. 1 i 78.

5 Colonel Ingoldsby's account, $i b$. 1185 .

${ }^{6}$ Fletcher to the Board of Trade, $i b$. 1098, I 144. 
not been able to refute the charges against him ${ }^{1}$, and was superseded by Lord Bellomont, advantage being taken of his recall to reunite the New England colonies and join them to New York. Thus with the Peace of Ryswick, William returned to the system of James, which he would in all probability have preferred throughout, had not the logic of the revolution decided otherwise.

The difference between the conduct of the war on the parts of France and England is well expressed by Bishop Burnet ${ }^{2}$.

The arbitrary frame of that government [France] made their King the master of the whole wealth of his people; and the war was managed on both sides between them and us with this visible difference, that every man who dealt with the French King was ruined by it; whereas among us every man grew rich by his dealings with the King; and it was not easy to see how this could be either prevented or punished.

\section{(e) The Interval of Unrest, $1697^{-1} 702$}

The Treaty of Ryswick included the colonial disputes in one comprehensive clause. All places captured or taken during the war-that is, after the declaration of war-were to be restored on both sides within six months. Commissioners were to be appointed to settle the disputed claims in Hudson's Bay, where both English and French had scattered trading settlements ${ }^{3}$. Thus the close of the war left the situation as it was at the beginning, and mutual confidence far from being achieved.

\section{French aggression}

In 1697 there is news of a French company in formation to settle colonies between the 3 th and 4 oth degrees of latitude, in the regions discovered by La Salle; and royal permission was gained for this area to be held as a fief from the crown ${ }^{4}$. There were also urgent appeals for expenditure on New France, for the development of its many productive potentialities in wine, salt, corn, shipbuilding, naval stores and fisheries ${ }^{5}$. French

${ }^{1}$ See below, p. r6o. $\quad 2$ Burnet, Hist. of My Own Time, Bk. vi.

3 Du Mont, Corps Universel Diplomatique, Vol. vil, Part II, pp. 400 et seq.

4 Letter from Paris, C.C. $1697^{-8}, 130$.

5 M. Denys to the King of France, $i b .848$. 
restrictions were placed on foreign vessels entering their ports ${ }^{1}$; whilst claims were set up to the Kennebec and St George River territories $^{2}$. In November, Bellomont wrote to Nicholson, saying that the French had obtained a foothold among the Dowaganha Indians behind Virginia, and suggesting efforts by the merchants of that colony to oust them-an easy task, considering the nearness of Virginia ${ }^{3}$. Livingston, too, writing from Albany, complained that the French were 'making a considerable settlement at the mouth of Mississippi, and were endeavouring to encompass the English behind ${ }^{4}$.' In Nova Scotia, also, the inevitable fishery quarrels were soon resumed $^{5}$; as also in the coastal regions of New England, and that question was added to the list before the commissioners for Hudson's Bay ${ }^{6}$. In I699 again proposals were put before the French King urging the development of New France from the mouth of the St Lawrence to the English border; particularly to supplant the Dutch and English trade in provisions and timber ${ }^{7}$; and the report of the Navy Board states that the French were encroaching twelve leagues into the English territory-land good for naval stores ${ }^{8}$. In October French aggressiveness was conspicuous in the arrival of a new governor for Port Royal, with ships and men, and under orders, as he expressed it, 'to hinder, conformable to the Treaty of Ryswick, all English vessels coming to fish in sight of the lands of this province'; and while laying down this intention, he proposed a treaty of neutrality in case of war. The Massachusetts council refused to sit with folded hands under such presumption. Neutrality, they replied, might be arranged, but the orders about fishing 'are so far from being conformable to the Treaty of Ryswick that they are directly contrary to the Vth article ${ }^{9}$ '

1 Blathwayt to Popple, C.C. $1697-8$, 880.

2 Benjamin Jackson to the Board of Trade, $i b .986$.

3 The Earl of Bellomont to Nicholson, C.C. I699, 77 (i).

4 Livingston to the Board of Trade, C.C. I7OT, 436.

5 James Vernon to the Board of Trade, C.C. I699, 9.

6 Board of Trade to Bellomont, ib. I5.

7 M. Denys to the King of France, ib. 22, ii.

${ }^{8} \mathrm{Mr}$ Bridges to the Commissioners of H.M. Navy, $i b .22$, i.

9 Correspondence between French Governor of Nova Scotia and Massachusetts Council, C.C. $I 7 O I, 785$ ii, iii. 


\section{The Indian danger}

The Indians were moreover a constant source of disagreement. The Five Nations and the River Indians had decreased in numbers from 2800 to 1300 during the $w^{1}{ }^{1}$; and the French policy was, according to Bellomont, to destroy all they could not debauch or inveigle. At the rate they had been destroyed during the war and since, he added, they would be extirpated in a few years ${ }^{2}$. Frontenac sought at first to maintain that the Five Nations were not included in the peace treaty; but Bellomont neutralized this move by promising help to the Indians if attacked; and he also used Frontenac's persistent refusal to give up his Indian prisoners to turn the scale in the English favour ${ }^{3}$. Meanwhile French missionaries and Jesuits continued their activity, and were still, spite of protests, allowed within the territories claimed by the English crown ${ }^{4}$. The Indians themselves Bellomont found to be much terrified because of their own diminution and because

the slender appearance we make on the frontier in the poorness of our forts and the weakness of our garrisons makes us contemptible in their eyes, whereas the French allure them by the good figure they make, and several good forts of stone, especially Cadaraqui, which Fletcher neglected to demolish when it was deserted two years ago ${ }^{5}$.... Some of the old crafty Sachems of the Five Nations have asked-whether they thought 'em such fools as to believe our King could protect 'em from the French, when he was not able to keep his soldiers in a condition as those in Canada are kept-who by the way are duly paid every Saturday in the year ${ }^{6}$.

Bellomont was obliged to walk warily in these affairs; and he chose to ignore the murder of five Senecas by Western Indians under French influence, lest he should assume French sovereignty in their country, although he was convinced that the attack came in reality from Canada?. He especially urged on

1 Bellomont to the Board of Trade, C.C. $1697-8$, 978, vii.

2 Bellomont to Nicholson, C.C. I699, 77 (i).

3 New York Agent to Popple, C.C. $1697-8$, 1039; Minutes of Council in Assembly, New York, C.C. $1699,198$.

4 Secretary of Massachusetts to Popple, ib. 83.

'Bellomont to the Board of Trade, $i b .250$.

C.C. $1700,666 . \quad 7$ C.C. 1699,878 . 
England the building of a fort in the Onondaga country, and the sending of Christian missionaries among the Indians. 'If both these desires are not complied with next summer,...I shall look on the Five Nations as lost from us irrevocably'.' Protestant ministers, however, were hard to recruit for this work. As for the fighting strength of the Indians, French influence had again made a notable alteration. 'Formerly roo of our Indians would have made 1000 of 'em [the Western Nations] run; but now they will fight on the square ${ }^{2}$.'

In I700 the Indian situation became critical. In January and February came reports of 'an ugly alarm of a general insurrection of all the Indians in all these Provinces, this April or sooner, which has mightily frightened the English ${ }^{3}$. A rumour was being spread by the French that King William had ordered all the Indians in the plantations to be disarmed, 'in order to a total extirpation of them ${ }^{4}$; and that Bellomont was prepared to carry out these orders by the use of poison ${ }^{5}$. The agents of Louis made much of the English disarmament order, concealing their own instructions which were to the same effect ${ }^{6}$. The colonies were now thoroughly alarmed. Massachusetts in fear provided for the levying and disciplining of soldiers, the erection of courts martial, the arrangement of transport, ammunition supplies, and a system of look-outs; and sought to conciliate the Indians, but did not neglect the while to prepare the militia and arrange for assistance to be sent to the other colonies.

We sat but nine days, and passed twelve Acts, which was such a despatch as was never known in this province....But whether the sudden march of the forces I ordered to the frontier towns did not operate more effectually is a question,

wrote Bellomont ${ }^{7}$. Again in March further rumours appeared. Most of the Indians had accepted as a fact the English policy of extirpation; whilst the French were insinuating that 'the Virgin Mary was a French lady, and Our Saviour a Frenchman, but the English are heretics, and it will be a meritorious service to kill Englishmen.' The design was evidently to lie still until

\footnotetext{
l C.C. ז699, гог 1 .

3 C.C. $1700,167$.

2 Bellomont to the Board of Trade, $i b .267$.

Board of Trade to the Lords Justices, $i b$. 812.

6 Bellomont to the Board of Trade, ib. $167 . \quad 7$ Ib. 345.
} 
English America believed in peace, and then to attack suddenly. How much of these rumours was based on fact is uncertain. Livingston at Albany believed the Five Nations to be innocent; whilst the Pennicooks sent to the governor and council 'to vindicate themselves against the false reports of their designing an insurrection ${ }^{1}$.'

At home, the government shared the alarm. When the rumours were reported, a special meeting of the Board of Trade was called, with the attendance of the high officers of state; but this meeting could only recommend what ought to have been done throughout, namely the making up of arrears in the pay and clothing of the regular troops, and the completion of their nominal strength of 400 , with a vote of $£ 500$ towards a fort at Onondaga, $f^{800}$ for presents to the Indians, of which $£$ roo should come from the home treasury, the remainder from the colonies ${ }^{2}$. What help did come actually from home was hindered by difficulties raised in the ordnance office ${ }^{3}$.

Bellomont meanwhile insisted on a fort being built at Cadaraqui. At Boston the council hesitated, but Bellomont stood firm, and had his way. He then held a conference with the Five Nations, who kept him waiting a fortnight before they could trust him sufficiently to join in a parley. They were even then sullen and out of humour; 'but by degrees I brought 'em to perfect food temper,' and French messengers of discord arrived in vain ${ }^{4}$. Bellomont added in his report that if similar alarms were to be prevented for the future, the English should avoid such cases of harshness in their treatment of Indians as undoubtedly had often occurred, "which is not the way to propagate Christianity among them ${ }^{5}$.' The danger if real was averted, and by the following year (I70I) the Indians were 'in admirable temper...firm in their obedience to his Majesty, and friendship to us,' expressing loyalty to their 'great lord and master, the King of England, called by us Corachkoe, by the Christians, William III.' Thus when the French pressed for

1 Bellomont's letters and Board of Trade Journal, C.C. I700, 167, 325, $34 \mathrm{I}$.

2 Board of Trade to the King, ib. 357.

3 Earl of Jersey to the Board of Trade, $i b .436$.

4 Ordnance Office to the Board of Trade, $i b .570$.

5 Bellomont to the Board of Trade, $i b .953$. 
neutrality among the Indians in case of the outbreak of war, the lieutenant-governor of New York would not hear of the proposal $^{1}$.

\section{Bad state of defence}

These Indian alarms may of course have been entirely groundless. There were ample opportunities for such a panic, in the bad state of defence. Bellomont from his arrival threw great blame for neglect on Fletcher ${ }^{2}$; and some of the measures adopted by the latter were undoubtedly open to criticism, notably his system of granting land in vast quantities to a few holders, by which local defence was not made easy. 'His large grants to single persons without due caution for improvement was not for your Majesty's service, nor did it tend to the settlement of those parts' wrote Bellomont; and the Lords Justices of England therefore gave orders that all legal methods should be put into practice for breaking and annulling these 'exorbitant, irregular, and unconditional grants ${ }^{3}$.' Whether or not Fletcher was chiefly to blame ${ }^{4}$, the state of defence in New York was bad. The troops were weak, needing 200 recruits; they went for two years with hardly any pay, except through the Governor's [Bellomont] credit, which in 1699 he had strained so far that the victuallers were unwilling to trust him any further ${ }^{5}$. In February of that year, the Board of Trade indicated how low the numbers of the New York troops had fallen, by recommending the raising of $25^{\circ}-300$ men to make up their full complement of $400^{6}$. 'All the old loyalty of this province is extinguished,' wrote the attorney-general of New York ${ }^{7}$. The soldiers themselves were in a miserable condition, 'almost naked, and likely to perish by reason of their great arrears ${ }^{8}$.' They

1 Lieutenant-Governor Nanfan to the Board of Trade, C.C. I70I, 9r5.

2 Bellomont to the Board of Trade, C.C. $1697-8,921$.

3 Board of Trade to the King, C.C. $1699,167$.

- Bayard, the anti-Leislerite Councillor, who had however quarrelled with Fletcher, says that the latter did his utmost to preserve the frontier. Bellomont tends throughout to favour the Leislerites (C.C. $1697-8,988$, xviii).

5 Agent of New York to the Board of Trade, C.C. I699, 121.

${ }^{6}$ Board of Trade to Secretary Vernon, ib. 128.

7 Attorney-General of New York to Blathwayt, C.C. I697-8, 994.

8 Board of Trade to the Lords Justices, C.C. $1700,812$. 
were 'the swearingest and drunkennest ever known in the world. The officers are taking to keep publick-houses,' and could not be broken of the habit which Bellomont was forced to condone during their days of extremity ${ }^{1}$. The forts at Senectady and Albany were scandalously weak; at the latter place the state of the fortifications was such that the government dare not fire a gun upon them. The forts were more like pounds to impound cattle ${ }^{2}$; the soldiers in a shameful condition of exposure; and the inhabitants had declared their intention of deserting the town if war was declared ${ }^{3}$. Bellomont, with his customary zeal against everything which savoured of Fletcher's influence, put the responsibility for Albany's plight upon Livingston, whom he accused of 'pinching an estate out of the poor soldiers' bellies 4.' 'To be plain with you,' he concluded, 'I would not stay a week here, were it not that I have a mind to accomplish the designs I am upon,- - of securing the Five Nations, building a fort in the Onondaga country, and arranging for the supply of naval stores from New England ${ }^{5}$. During all these complaints the Board of Trade was sending out recommendations for repairs to be effected and paid for by the New York assembly, the other councils and assemblies to contribute ${ }^{6}$. The Lords Justices in 1699 , noting the colonial demand for stores and the fact that necessary forts had not yet been built, inquired how the colonists could be compelled to furnish themselves with such stores and to make provision for their own safety $^{7}$. The Board of Trade however decided to help the colonies and gave Bellomont power to draw on the treasury for sums up to $£ 2000$, for repair of fortifications and suchlike works ${ }^{8}$, writing also to the other governors 'to excite them to contribute.' The need for such a measure was shewn by the fact that in 1700 Bellomont, knowing the necessity for repairs, had spent some of his own money in providing stores, which, not being confirmed from home, left him some $£$ ioo to the bad.

1 Bellomont to Vernon, C.C. I700, 850 .

2 Bellomont to the Board of Trade, C.C. I699, 343.

3 C.C. 1700,845 .

${ }^{4} \mathrm{Ib}$.

${ }^{5}$ Bellomont to Vernon, ib. 850 .

6 Board of Trade to Bellomont, ib. 1037.

- R. Yard to Wm Popple, C.C. I699, 833 .

8 Secretary Vernon to the Board of Trade, C.C. I700, ro54. 
Bellomont was further concerned with a scheme by which the lands granted in exorbitant quantity by Fletcher should be parcelled out in unalienable plots to officers and soldiers after seven years service, with liberty to the grantee to quit the service. A small quit rent would be paid to the King; to whom alone the lands could be made over-lest the needy soldiers should in a few hours part with their property for a gallon of rum. By this means the country would gradually be peopled, and the frontier towards Canada strengthened. Had such a scheme been practised twenty years previously, 'there had been this day a thousand families on the land granted to Dellius [one of the large landowners], which would have been a force sufficient to make a stand against all the French of Canada ${ }^{1}$.' This scheme was supported from home, but depended upon the speedy cancellation of Fletcher's grants, which was a longprotracted process ${ }^{2}$.

The governor was no more hopeful of affairs in Boston than in New York. 'There being now a peace, they have no remembrance of a war,' is his lament ${ }^{3}$, not peculiar to the Puritans of Massachusetts, or to the year 1700 . The fort at Boston was, according to Bellomont, the poorest he ever saw; and this being so the government was not likely to build forts in the more distant province of Maine, where there was urgent need ${ }^{4}$. In January $170 \mathrm{I}$, instructions from home required Massachusetts to provide for its own defence, so that such a disgrace as the loss of Pemaquid should not be repeated ${ }^{5}$; in June, a supply of powder was sent from home, but with the proviso that this must not be taken as a precedent; since the colony was alone responsible for an adequate supply ${ }^{6}$. Massachusetts however, in welcoming this present, expressed the hope that it would extend to a further supply of stores of war; and again protested that they were unable to repair the forts of Pemaquid and New Hampshire?.

1 Bellomont to the Board of 'Trade, C.C. $1699,740$.

2 See below, pp. 175-6. 3 C.C. I699, 746.

5 Draft letter to Bellomont, C.C. I7OI, 17 .

6 Order of King in Council, ib. 594.

7 Council and Representatives of Massachusetts Bay to the King, ib. 106I (ii) and (iii). 
In January I 701 , a letter from the Board of Trade informed Bellomont of a detailed system of quotas to be sent to New York by the other colonies in time of war, and also recommended contributions from the neighbouring colonies to the fortifications on the northern frontier. The news of these instructions provoked the usual protests. In Virginia, the House of Burgesses

resolved nem. con. that the letter requiring $£ 900$ to New York frontiers has been obtained by false suggestions and misrepresentation...for the security of [New York's] Indian trade;...that forts there will not help Virginia; our condition is such that we are not able to contribute $£ 900, \ldots$ and the sending of men would be prejudicial to His Majesty's interest at home, and would endanger the safety of this colony ${ }^{2}$.

Governor Nicholson, with past experience in New York, tried to induce a more friendly attitude, but by October he was obliged to write to Nanfan, the lieutenant-governor of New York, that there was not the least ground to depend upon having any assistance in men from Virginia ${ }^{3}$.

In Maryland, Governor Blakiston was disquieted at the reception given to the royal orders by the neighbouring colony. 'If it should not be done in Virginia, I doubt it will make our Assembly here boggle, for they are glad to take hold of any example, when it is to save their money ${ }^{\prime}$; and he later decided that it was wiser not to call the assembly on the question, so unpromising was the colony's attitude ${ }^{5}$. Pennsylvania took up the same position. According to Penn,

the negative of Virginia will render it more difficult everywhere, considering the dignity of that colony, and the vigour of the Commander-in-Chief to pursue advices from home....Pennsylvania would not be prevailed with to think of any supply for the fort ${ }^{6}$.

1 Draft letter to Bellomont, C.C. I7OT, I6 (i).

2 Journal of Virginian House of Burgesses, $i b .748$.

3 Nicholson to Nanfan, $i b$. 96I (ii). In connection with the defences of Virginia, it may be mentioned that in $170 \mathrm{I}$ an act was passed for granting land to societies in common for settlement of the frontiers, with no taxes or levies for 20 years and no military service except their own defence, for which one man fully armed had to be kept in every 500 acres (Statutes of Virginia, I 701, p. 204).

J Journal of Virginian House of Burgesses, $i b .8 S_{2}$.

3 Blakiston to the Board of Trade, $i b$. 1062.

- Penn to Nanfan, ib. 961 (iv). 
Finally Massachusetts:

The quota required from this province for the assistance of New York do's much startle His Majesty's subjects here, who apprehend themselves to live more open and in danger of an invasion than that province, and altogether as unable (if not more) than they to defend themselves without further assistance, and they humbly hope for His Majesty's Royal Grace therein ${ }^{1}$.

Thus, upon the renewal of war in 1702 , the old problems arose about its prosecution-problems of policy, personnel and initiative-as they arose in the previous war. Moreover, the death of Bellomont in r 701 not only removed an able and energetic governor, but separated New York and New England again, each having henceforward its own governor ${ }^{2}$. In one respect however, the situation was simplified: administration and defence were not in the anarchy of revolution, but in the hands of legal authority.

\section{( $f$ ) The West Indies, 1697-1702}

\section{French aggression}

In the West Indies also the interval after Ryswick was a period of unrest. In Jamaica, the French continued to land in the outlying parts after the peace ${ }^{3}$; in 1699 a quarrel arose between the English governor of the island and the French at Petit Guavos, who had received and acquitted one Kelly, a pirate, whom Beeston sought to punish; and complaints were also made that the French were making efforts to establish trade with Spanish America, to the detriment of Jamaica ${ }^{4}$. In St Kitts, the dual occupation was bound to lead to trouble; and the French ambassador did not wait long before complaining of spoils committed by the English on the French part of the island ${ }^{5}$. The English commissioners for settling the island refused to give up houses occupied by any Frenchmen in the English part before the war, and would not negotiate at all on

1 Lieutenant-Governor Stoughton to the Board of Trade, C.C. I7oI, 500.

2 See below, p. I3 I.

3 Beeston to the Board of Trade, C.C. $1697-8$, 91. $1699,45$.

4 Letter from Porto Bello, C.C. I699, 846 .

5 William Popple to Sir Charles Hedges, ib. 64. 
the matter ${ }^{1}$. Also, French claims on St Lucia and Tobago caused much dispute. In St Lucia, the governor of Barbados was ordered to assert English rights ${ }^{2}$. From a tactical position the island was too near Barbados to be lightly given up. Governor Grey therefore demanded the withdrawal of the French ${ }^{3}$, but was met with an indignant refusal, and the affair passed into diplomatic arrangements which were broken by the renewal of war. The French claim in Tobago was weaker, and the insistent assertion of English rights carried the day ${ }^{4}$.

\section{Defence}

In the matter of defence, the greatest groanings now proceeded from Barbados, which had suffered greatly from 'the long unhappy war and generous mortality.' Many families were dead, and others reduced to great poverty, large tracts of land were waste which formerly made great production, and many plantations were utterly ruined ${ }^{5}$. In November 1699 the assembly dared not impose so great a tax as the fortifications required; necessary though they were ${ }^{6}$; and the following year it insisted that the $4 \frac{1}{2}$ per cent. export duty should be used for the purpose ${ }^{7}$. However, the Barbadians appear to have gained to some extend the sympathy of the home government, a year later. They had again asked for the employment of the $4 \frac{1}{2}$ per cent. duty for defensive preparations, and although their request was refused, the Board of Trade added that 'by their zeal the Barbadians deserve help.' The help however does not materialize ${ }^{8}$.

While Barbados thus received encouragement but not help, Jamaica gained help with discouragement. In r70I, it was decided to send stores to the island as demanded, 'it being necessary,' according to the Board of Trade, 'that the plantations be assisted and supported from England in their defence,

1 M. de Pontchartrain to M. le Comte de Tallard, C.C. I699, 264.

2 The King to Governor Grey, ib. 939.

3 Governor Grey to Marquis d'Amblimont, C.C. 1700,661 .

4 Board of Trade recommendation and Order in Council, ib. 9, 10.

5 Barbados to the Board of Trade, C.C. I69I-8, 272.

6 Assembly of Barbados to Capt. Edwards, C.C. 1699,954 (iii).

3 Barbados agents and others to the Board of Trade, C.C. I700, 98I.

8 C.C. I7OI, $177,220,272$. 
which they will not be able otherwise to carry on ${ }^{1}$ ' By the time the stores were actually sent however, the prevailing policy seems tinged with caution and suspicion, for the stores were to be strictly under the charge of Governor Selwyn, and were not to be used except in case of absolute necessity, or when the assembly should pay for them. 'The inhabitants are able in good measure to provide for their own defence 2 .'

The Leeward Islands were deprived in December 1699 of their able governor Codrington ${ }^{3}$ - unfortunately in the shadow of corruption, which few governors could resist. His death occurred just at the time when charges were being preferred against him at home. His son, also Christopher Codrington, scholar and soldier, was appointed to succeed him, but refused to set out until the arrears due to his father had been paid, and did not arrive until the end of 1700 . Here also the home departments were attempting to avoid being squeezed, as they thought, by undeserving colonists. The ordnance office in this case said that $£_{2000}$ of stores required for St Kitts, although in the opinion of the principal officers of ordnance absolutely necessary for defence, could not be supplied unless the office was reimbursed 4. Meanwhile the islands were weak, and 'none could hold out long, if an enemy should appear before them,' said Colonel Fox, the deputy governor ${ }^{5}$. Codrington on his arrival feared the outbreak of war, and asked Barbados for the loan of a frigate to attack St Kitts, when the declaration should come. The frigate arrived, in bad condition; but Codrington had to be thankful for its arrival at all, since Governor Grey sent it on his own initiative after a request from his assembly that he would not do so ${ }^{6}$. Codrington also suggested that the two governments, Barbados and the Leeward Islands, should be united, since 'Barbados has no inclination to serve or save these Islands, nor has one of them to help another ?.' As an example of the state of defence in Antigua, it was mentioned

1 Board of Trade to Secretary Vernon, C.C. I7OI, 463.

2 Correspondence between Board of Trade and Lords Justices, $i b .725,667$.

3 Nevis to the Board of Trade, C.C. $1697-8,1089$.

4 Ordnance Office Report, C.C. I699, 884.

5 Colonel Fox to the Board of Trade, C.C. I7or, 640.

6 Codrington to the Board of Trade, $i b .516$.

7 Ib. 997. 
that when in I7or one Major Martin was murdered by the slaves, it transpired that 'scarce a man could find a gun; and he that would had neither powder nor ball nor sword ${ }^{1}$.' The new governor also received discouragement in Montserrat, where he went to secure recruits for the attack on the French under Governor des Gennes in St Kitts, and found not three men willing to enlist ${ }^{2}$. However Codrington, who bears some resemblance to Bellomont in his enthusiasm and determination, rejected a suggestion of West Indian neutrality, put forward by the French: 'I told them that whenever they made me a visit I should not fail to give them a hearty welcome; and we should not think of another neutrality until we had forgotten the good effects of the last ${ }^{3}$.' Writing again, with the renewal of war imminent upon England, Codrington made a boast destined to be not far short of fulfilment: 'My will is made and my houses set in order. If I hear of war at midnight, I shall visit $M$. des Gennes at break of day ${ }^{4}$ '’

\section{(g) Conclusions}

The eight years of war, following the accession of William III, brought to light several important facts. The revolution in the colonies first of all resulted in a criminal neglect of defence; and thus the conclusion of hostilities brought only the preservation of that restless peace, the impossibility and illogicality of which were rapidly becoming obvious. Had an energetic and well-considered scheme of operations been carried out, it does not appear unlikely that the French could have been driven from their threatening strongholds. Certainly the actual policy pursued had a demoralizing effect. The war shewed moreover a lack of cooperation between the colonies, and the absence of that feeling of common interest which was only with difficulty excited nearly a century later. As a result, help was sent from England, but vaguely, and not as a matter of course, witness the caution to Massachusetts that they must not assume a pre-

\footnotetext{
1 Codrington to the Board of Trade, C.C. I7OI, I I32, ii.

2 Colonel Hodges to Governor Codrington, $i b .784$, ii.

3 Codrington to the Board of Trade, $i b .516$.

+ $I b .997$.
} 
cedent from assistance in ammunition ${ }^{1}$. Between these two stools, an adequate conduct of the war fell to the ground. The help sent was often bad, the delay generally considerable; whilst lack of knowledge resulted in the sending of unsuitable supplies. It may well be that mismanagement in colonial affairs was not proportionately greater than that in other departments, but this fact does not diminish the importance of that mismanagement.

In a broader sense, however, it was also true that the English government was not aware of the real position in America, until its eyes were partially opened by the war with France, which forced the problem of defence upon public notice. The government had first to decide that it wished to preserve the American colonies-that is, it was compelled to think imperially, if only in a very rudimentary fashion. The next step was to decide what its own attitude to British America should be; where the burden of defence was to fall. Here the war brought no satisfactory settlement, for the government were totally unable to carry out a consistent and logical policy; and the decision implied was that England would assist in defence, rather than that it should be neglected, but that, on land at least, the colonies must take the initiative. The mother country would not. Thus the history of the war gives the impression of a struggle between the colonies and England, in which the colonies had the upper hand; for, could they only hold out in refusing to carry out their own defensive operations, England would eventually send supplies. Of course, looking back in the light of later events, it appears that the colonists should in reality have feared France to such an extent that they could not dare to offend the English government. But whilst the fear of France is constantly on their lips, it does not appear to have provoked desperate action. Thus, if the English minister saw the danger of French aggression, whilst the colonial leaders did not, the natural result was that England should send help, rather than waste time in debating what appeared to be a minor point of colonial constitutional policy. Moreover, the statesmen who could see this danger would also wish to prevent the American governments from neglecting their own duties and relying on

1 Order of King in Council, C.C. I7OI, 594. 
the protecting arm of England. Their representative opinion is shewn in the Report of the Council of Trade to the Lords Justices in $1696^{1}$.

\section{The Council of Trade's Report, 1696}

This report began by describing royal assistance to the colonies, especially the supply and maintenance of four companies of infantry at New York. The Queen's orders concerning quotas, it proceeded, had evidently been carried out uncertainly and imperfectly. It was incredible that the governor of New York, in the midst of 40,000 English, should say that he had only the companies in the King's pay that he could depend on for defence. The council's conclusions were: first, that there was force enough in the colonies for defence; second, that the colonies must be united, for even an increased force could not secure more than Albany, and the French would then attack another point; third, that as the proprietary governments could not thus be united, a military captain-general must be appointed to receive quotas of men, and of money in the case of Quakers. Presents for Indians must be raised, and training given to their youths, ministers also being sent to preach Christianity to them. The report added that the colonies which protested the danger of attacks on their own borders were not in particularly good state of defence.

This was all very good, but the council could make no provision for the one probable eventuality. The revolution had brought in, or strengthened, representative government, for which it stood in England; and the home government never seemed to allow in their war policy for the increased power of the assemblies. Occasional protests were sent against an assembly which claimed power over revenue and salaries, but in questions of raising men and money for the war, it appears that England still thought it sufficient to instruct the governor to provide what was necessary, whereas it generally happened that the governor could not do it. If then the assemblies could refuse to grant help to other colonies-and experience had shewn that they had done, and would do so-what did the government, as

1 Board of Trade to the Lords Justices, C.C. $1696-7,286$. 
advised by the Board of Trade, propose to do? This is the great problem of colonial policy, first clearly seen to emerge in the war, and continuing until it culminated in the separation. For, with the accession of William of Orange, the problem became a struggle of principle. The revolution brought in self-government in a far greater degree than was indicated by the policy of James II, the assemblies having now the power to refuse help to their neighbours. On the other hand, William's accession introduced a determined struggle with France, which therefore required a strong aggressive and defensive policy in America. How could those two principles be reconciled? How could defence be organized without autocracy? In the West Indies, where sea-power greatly outweighed land policy, England bore the brunt of responsibility herself, and thus the problem never assumed menacing proportions. In America however it was a vital question. It was inaugurated by the accession of William III, and at his death there appeared no prospect of an adequate solution. 


\section{CHAPTER IV}

\section{THE POLITICAL ASPECTS OF COLONIAL POLICY}

A conflict was now beginning between rising political entities and methods of government which to them savoured of tyranny. A general absence of understanding and public spirit on both sides threatened to embitter the conflict, and natural obstacles in the way of harmony were very great.

\section{(a) Colonial Administration}

\section{Councils of Trade}

The revolution of 1689 did not disturb the English constitutional methods of carrying out colonial administration, but the new régime brought about noteworthy changes of personnel, which throw much light on the change of policy inaugurated by the Whig triumph in England. In Charles II's reign, colonial affairs had been the concern of a Committee of the Privy Council for trade and plantations; and this same committee had shewn activity under James II, in dealing with the proprietary and charter colonies. William III continued this method of administration by appointing a new committee, which he employed in commercial and colonial affairs until 1696.

The Stuart dynasty had in the main continued to follow the advice given early in the century by one of its most famous servants :

Let not the government of the Plantations depend upon too many Counsellors and Undertakers in the country that planteth but upon a temperate number; and let those be rather noblemen and gentlemen than merchants; for they look ever to the present gain ${ }^{1}$.

Thus in 1685 the committee which signed the order for the proclamation of James II in New York consisted of fifteen members, all of them peers, including the Archbishop of Canterbury the High Officers of State, and an imposing group of statesmen, Rochester, Halifax, Clarendon, Arlington, Sunderland, Bath, Craven, Bridgwater and others, Jeffreys being a

1 Bacon, Of Plantations. 
later name of distinction on the committee. William on his accession carried on this system, but appointed a new committee, of which Halifax and Bath continued their membership, the total number being now twelve, and including, in addition to the High Officers and several other peers, the Bishop of London, Sir Henry Capel (a lawyer previously noted for his exclusionist principles, and a commissioner of the treasury), Henry Powle (Speaker of the Convention Parliament, and William's most trusted adviser, a man of wide historical and legal reputation), and Edward Russell (the sailor who had served in earlier days under William, and was now treasurer of the navy) ${ }^{1}$. Thus the personnel of colonial administration was beginning to shew signs of progress towards a more specialized system. Any three of the body could form a quorum, and their meetings appear to have been frequent-often several times a week, though there were occasionally gaps of about a fortnight-and the mass of colonial business passed through their hands. This advisory committee however had to bear the brunt of trade losses resulting from the war, and in 1696 proposals were on foot in the House of Commons to establish a special board to supersede it. The King was opposed to the idea, but could not at first prevent the suggestion being carried forward. However by March 1696, the Commons' bill was dropped, possibly by the indirect influence of the plot to assassinate the King.

\section{Reorganization of 1696}

But in May a new board was created on similar lines by an Order in Council'2. The president of this board was the Earl of Bridgwater, who had served on the old Privy Council committee under James II but who as a supporter of the revolution had also the confidence and friendship of William. The only other peer on the board was the Earl of Tankerville, a former Monmouth rebel and an active revolutionist, also a close friend of the King. The eight salaried members of the board included John Locke (secretary of the Council of Trade under Charles II, with personal interests in trade, and a writer on economic

1 Order of King in Council, C.C. $1689-92,17$.

2 O. M. Dickerson, American Colonial Government, Chap. I. 
questions of the day), John Pollexfen (one of the Lords of Trade in 1675 , a man of great influence, and an advocate of the state regulation of industry), William Blathwayt (secretary to the old committee under William III), Abraham Hill (a member of the Royal Society), and John Methuen (the diplomatist). The successors of these men possessed for the main part similar qualifications. These eight members were paid frooo a year, and bore the great part of colonial administration. The High Officers of State were authorized to attend when necessary and when other public services permitted ${ }^{1}$.

\section{Duties of the board}

To this board was entrusted a threefold duty: the care for trade and manufactures, for the employment of the poor, and for the colonies. It had, however, no definite control over the important decisions of government, the most notable deficiency being in the appointment of governors, which remained in the hands of the Secretary of State. When the administration of this board had become more lax - it remained efficient throughout the reign of Anne-the colonial governor could afford to defy the board appointed by the same authority as himself. It is indeed possible to exaggerate the importance of the change brought about in 1696 . The most important result was one of those periodical bursts of energy which during the colonial period marked the whole series of committees and councils at their inception. There was plenty of work to be done, and a new and wisely chosen council was more likely to do it than a Privy Council committee which tended to fall into inattention and routine.

\section{Communication}

The new Board and its predecessors were alike dependent on poor means of communication. There being no mail boats, letters were sent in both directions by merchant ships; and, in addition to the risks of this informal method of transit, suffered from the indirect method of delivery, frequently being passed from hand to hand until they reached the addressee or were

1 Channing, Hist. of United States, Vol. Ir, p. 230, and Dickerson, op. cit., Chap. I, give many details. 
lost in the process. Sometimes they lay at an agent's house for long after their arrival across the sea. Thus the length of time for the passage of any letter varied from about two months to as much as two and a half years ${ }^{1}$. The important instructions to Phips, on which depended the entire success of Wheler's expedition against Canada, were despatched in February 1693 , but did not reach him till late in September of that year-too late to be of any use-in spite of the fact that Boston was on the direct route between England and the colonies. The more indirect routes took much longer time. Connecticut and Carolina suffered especially, receiving their letters by way of Boston (or New York) and Virginia respectively. These latter colonies were the best served, but even in their case, there are instances of letters being sent indirectly, with the consequent delay. Moreover, this difficulty of communication led to important constitutional difficulties. As will be seen later ${ }^{2}$, considerable importance in the friction between England and the colonies was attributable to the disputed questions of the right to allow appeals from colonial to English courts, the liability of customs officers to seek protection from England against legal proceedings in the colonies, and, more broadly, to the principle of restriction which was the core of the Navigation Laws. In each of these cases, it may readily be conceived that the disadvantages of bad communications and bad economic connection between the two continents were at least one main cause of the friction, and that the consequent quarrels were not entirely due to an American ambition to throw off the English connection as such.

Inter-colonial communications too was not easy. It is not always clearly realized how far the colonies were separated from each other in the early colonial days, when settlements had not yet grown to cover whole states, and when the geographical situation-the direction of rivers, and the inlets of great baystended naturally to divide rather than to unite. With no supply of good roads, long-distance communication by land easily became impossible, and the usual method of travel from one colony to another was by sea. This fact has important bearings

1 Dickerson, op. cit. gives many instances.

2 See below, pp. 123, 125 . 
on the attempted union of the colonies. A complete union was never suggested, and the difficulties even of a united New England can be seen when Bellomont, the general governor of that province, had considerable trouble in getting from New York to Boston'.

\section{(b) The Period of Phips and Fletcher}

The provincial governors formed the main link between colonies and mother country; and it is therefore necessary, for an adequate consideration of the relations existing between the two, to consider in some detail the personalities and careers of the principal governors. As it happens, the chief colonies during this period changed their governors at about the same time, so that grouping is easy. The first period is that of Phips, Fletcher, Andros and Nicholson, governors respectively in Massachusetts, New York, Virginia and Maryland.

\section{Phips in Massachusetts}

Sir William Phips was at one time a ship's carpenter, and his temperament was that of the sailor. He made several attempts to salve wrecked treasure-ships, and finally succeeding was knighted on his return to England. Then followed his appointment as Provost Marshal of New England. Soon after the revolution-during which he was in England-he was received into the Church at Boston, a necessary preliminary to the holding of office under that colony. After commanding the sea-forces in the expeditions of 1690 and I69I to Port Royal and Quebec, he was appointed governor of Massachusetts by the King in March $1692^{2}$. He does not appear to have been in general favour at his return to the colony after joining Mather in the negotiations for a new charter; and one writer from New England affirmed that Phips 'hears from his people that there will be another governor shortly, so he will make his life as comfortable as he can ${ }^{3}$.' His arrival found Boston in the midst of the memorable witchcraft scare, during which many un-

1 Board of Trade to the King, C.C. I699, 29.

2 Minutes of Nevis Council, C.C. $1689-92,2234$.

3 Joshua Brodbent to Nicholson, ib. 2283 . 
fortunate persons were sent to death or imprisonment on charges of magical malpractices. Phips did not at first doubt the various accusations, and made special arrangements for the trial of suspects; but later in the year he began to question the truth of ever-increasing charges of witchcraft, and stopped all proceedings, receiving the royal commendation for so doing1.

A striking characteristic of the new governor was an utter inability to work harmoniously with others of coordinate authority. With Fletcher at New York he kept up a constant feud. In 1693 the latter had occasion to send a messenger to Boston; but Phips received him with abuse, and expressed a wish to challenge his master to a duel, a contingency which Fletcher managed to evade. The messenger sent from New York to great Admiral Wheler had such a reception from Phips as to call forth an apology from one of the councillors present-an apology which was in itself a serious condemnation of one in Phips' position 2. 'The collector of customs in New England also complained of the governor's conduct to him, alluding to one specific charge of hindrance which he preferred against Phips as 'not the only occasion ${ }^{3}$.' As for the officers of the navy, the governor was generally at loggerheads with them. Capt. Fairfax, of H.M.S. Conception, complained of neglect and uncivil conduct by Phips ${ }^{4}$; whilst Capt. Short, of H.M.S. Nonsuch, suffered more than this and was in part a cause of Phips' recall. In such a chapter of acrimony it is difficult to assess the blame correctly, but the facts appear at any rate to condemn Phips more than Short. The governor accused the captain of unpunctuality in obeying his orders, and of not being in readiness to carry them out. He also obtained testimony from Short's subordinates to drunkenness and cruelty on the captain's part $^{5}$. However, be these charges true or false, Phips went on board the Nonsuch, knocked Short down, and proceeded to thrash him with his cane, the captain, hampered by a previous wound, being unable adequately to return the governor's ad-

1 Order of King in Council, C.C. $1693-6,33$.

2 Chidley Brooke to Fletcher, $i b .486$. See p. 75 above.

3 Commissioners of Customs to Lords of the Treasury, $i b .689$.

4 Capt. Fairfax to Mr Sotherne, ib. 4r-2.

5 Phips to Nottingham, ib. 88. 
dresses. Having thus shewn his authority, Phips suspended Short and appointed the gunner to the vacant command. Short, defended also by Captain Fairfax, attempted to justify himself ${ }^{1}$, but Phips was resolute, and put him on boardship to be taken home in confinement. The captain had however some supporters and succeeded in being taken to New Hampshire, where he was well received by the people, Usher the lieutenantgovernor being absent ${ }^{2}$. Phips followed up the attack by sending the purser to demand Short's surrender, but the opposite party in turn seized the purser. The governor now appeared on the scene himself, but was refused admittance by the President, and worked off his indignation by possessing himself of Short's baggage which he took back with him. By this time Usher had returned and made objections to Phips' interference, writing home to urge that a new governor should replace him in Massachusetts ${ }^{3}$. This quarrel between Phips and Usher was aggravated by disputes over the territory around the Piscataqua River, and the control of that river ${ }^{4}$; and by Phips making peace with the Eastern Indians without consulting New Hampshire ${ }^{5}$.

In Rhode Island also Phips found opposition, this time in resistance to his commission over the Militia; and the inhabitants accused him of appointing officers against the will of the 'Governor and Company' ${ }^{6}$ ' About the same time, the Connecticut Militia command was transferred from Phips to Fletcher? ${ }^{7}$ With the latter Phips was still in great disfavour, Fletcher alluding to his 'unmannerly conduct,' and speaking contemptuously of the 'jargon in New . England, and that machine their Governor.' He also accused Phips of protecting one Gouverneur, a released Leislerite who had been stirring up faction in New York. Phips denied that the man in question had committed crime enough to be handed up for ${ }^{8}$.

In January I694, the Council of Trade decided, in view of

${ }^{1}$ Capt. Fairfax and Capt. Short to the Admiralty, C.C. I693-6, 224-5.

2 Phips to Nottingham, $i b .247$.

${ }^{3}$ Usher to the Board of Trade, $i b .258 . \quad{ }^{4}$ Phips to Usher, $i b .372$.

${ }_{5}^{5}$ Usher to Nottingham and to the Board of 'Trade, $i b .647-8$.

6 Phips to Nottingham, $i b$. 108; Address of Rhode Island to the King and Queen, ib. 524 .

: Ib. 310.

8 Fletcher to Blathwayt and Nottingham, ib. 84,86 ; also 107. 
Short's case and other charges against Phips $^{1}$, to recommend his recall, that the charges might be answered; and on this recommendation the irascible governor was summoned home ${ }^{2}$. Some months however elapsed before these orders could be carried out, and in the meantime Phips embroiled himself with his own assembly in Boston, about the right to refuse admission to duly-elected members ${ }^{3}$. In 1695 he returned to England in bad health; and in June he died, before the charges against him could be established ${ }^{4}$. Joseph Dudley, proclaiming that during Phips' tenure of office not a single good thing had been done, was silenced by mention of a peace with the Eastern Indians in $1693^{5}$.

\section{Fletcher in New York}

Benjamin Fletcher, Phips' contemporary in New York, was one of the many men in colonial history who, arriving from obscurity, played an important part in administration, and returned again to obscurity. His character is hard to gauge. The records and dispatches of his period of rule seem to shew a man of determination, with a constant purpose to maintain New York against French and Indians on the one hand, and against faction on the other. The arrival of Bellomont however, brings new impressions. The latter, whose word should command respect, accused Fletcher of neglect and corruption, of stirring up faction, and of a foolish land policy. The conclusion therefore appears to be that the governor was a man of strong character, tinged with the usual corruption of self interest, and suffering from a tendency to extremes in everything, doing well against the French, making big mistakes in policy.

Fletcher's predecessor in New York, arriving in March I69I, lived only long enough to see the execution of Leisler and his Lieutenant, and in July the position was again vacant. Major Ingoldsby, who had accompanied Sloughter, carried on the government as commander-in-chief, and prevented the colony returning to its previous anarchy. In September 1692, Fletcher

1 Minutes of the Board of Trade, C.C. I693-6, 826.

2 The King to Phips, ib. 862,879 .

3 Nathaniel Byfield to Joseph Dudley, ib. 1089.

4 Agents of New England to the Lords Justices, $i b$. 1876.

5 Ib. 1089 . 
arrived, to the grief of Ingoldsby, who lamented the appointment on the ground that since he himself had received no pay, he would be obliged either to leave the place or starve, now that the government was taken from him ${ }^{1}$. The new governor's report on his arrival was discouraging although the council and the House of Representatives of New York expressed gratitude to the King and Queen for the appointment of such a governor as Colonel Fletcher ${ }^{2}$. He found that the revenue much indebted, the burden of Albany being the chief grievance. (The cost of Albany to New York for the period from March r69r to September 1692 was estimated at $f_{1} 10,867^{3}$.) 'The people were divided, contentious, impoverished....The two parties seem implacable and will so weaken each other that we may become a prey to our enemies ${ }^{1}$.' In this connection Fletcher threw out an accusation against Phips, that he was 'the bellows that blows up the dying embers of former discontents ${ }^{4}$.'

Fletcher's chief work lay in the conduct of war with France, and the needs of defence brought him into intimate contact with the surrounding colonies. In 1692 the government of Pennsylvania was added to his command, by a step which seemed to indicate an attempt to increase royal control over the proprietaries. Penn, as was natural, protested.

The government [of Pennsylvania] is inseparably my property.... I hope thou wilt tread softly in this affair. The discouragement of those who went thither in the faith of the Crown, and the decay of their trade (the return of ten years toiling in the wilderness) are my prevailing motives in writing to you ${ }^{5}$.

Fletcher was proclaimed in the Quaker colony, and appointed William Markham, the former Secretary, as his lieutenantgovernor. Penn however maintained his objections, complaining to the Queen and Privy Council of the inclusion of Pennsylvania in Fletcher's commission ${ }^{6}$. Fletcher made counter-charges

1 Commander-in-Chief of New York to the Duke of Bolton, C.C.I689-92, 2285 ; Council and Representatives of New York to the King and Queen, ib. 2462 .

2 Account of the cost of Albany, ib. 2463.

3 Fletcher to Blathwayt and Nottingham, $i b .2459-6 \mathrm{r}$.

4 Fletcher to Dudley, C.C. I693-6, 13.

5 Penn to Fletcher, C.C. $1689-92,2667$.

- Penn to the Queen and Privy Council, C.C. I693-6, I1 27. 
against the Quakers, who had apparently been incited by Penn in a letter to oppose the royal commission ${ }^{1}$. At any rate the colony refused to grant Fletcher the measures for defence which he required ${ }^{2}$. In face of this difficulty, the Lords of Trade sought the opinion of the Law Officers, who decided that in cert in exigencies the crown had a right to grant such a commission over a proprietary government, but that when these reasons failed or ceased, the rights of government belonged to Penn $^{3}$. The Lords of Trade then summoned the Quaker to state what conditions he would fulfil if the proprietary government were restored to him. Penn agreed to go to his colony and take actual charge, transmit the royal orders, secure obedience to orders about the quotas for defence, continue the present lieutenant-governor, submit the government back to Fletcher if the royal orders should not be obeyed, execute certain of Fletcher's laws passed in 1693, and subscribe a declaration of fidelity to the King and Queen. In the meantime Penn pointed out that the assembly had passed an act of submission to the royal government. The Lords of Trade therefore recommended the restoration of Penn to his proprietary rights of government, reserving to Fletcher only the right to demand eighty men and assistance in the defence of New York ${ }^{4}$. Fletcher's commission over Pennsylvania was accordingly revoked, and the Quaker colony continued its prosperous course under private government ${ }^{5}$. In fourteen years from its settlement Philadelphia had become nearly equal to New York in trade and wealth, and yet, according to Fletcher, it was rather a hindrance than a help to its older neighbours ${ }^{6}$. In 1696 the assembly declared Penn's former charter void, as too narrow, and drew up a bill to qualify themselves to make laws. This Bill, 'drawing up a constitution and scheme of government for Pennsylvania,' was endorsed: 'Presented to Governor Markham by the Quakers, which they desired to purchase to be enacted for the sum of

1 Minutes of the Lords of Trade, C.C. ${ }_{1693-6,860 .}$

2 Fletcher to Blathwayt, ib. 395-7.

${ }^{3}$ Privy Council Order, ib. 1138.

4 Minute of the Lords of Trade, $i b$. I $18 \mathrm{I}$.

6 Fletcher to the Board of Trade, C.C. $1696-7,25$.

5 Ib. $1238,1251$. 
$£ 200$ to be given as an assistance to New York ${ }^{1}$.' Markham referred the whole question to Penn, and meanwhile was unable to assist Fletcher in the war ${ }^{2}$.

Connecticut also had been a thorn in the flesh of the English governors since the revolution. Ingoldsby complained in I69I that the colony was pretending to independence ${ }^{3}$, whilst an address of the freeholders in 1692 claimed that the elections, by which the present government in Connecticut was established, were illegal and contrary even to its former charter, whose resumption however had not been justified. The government so established was, they asserted, arbitrary and despotic, renouncing the laws of England. 'The Throne is made a footstool, and the Crown a football for an usurping corporation ${ }^{4}$.' According to Fletcher, Connecticut was 'a sort of republic, and all the better sort are much dissatisfied, and wish to be united to New York ${ }^{5}$ '' There was also evidence of quarrels among the magistrates, with a consequent instability of justice ${ }^{6}$. In 1693 the complaints of New York were thus far answered that the command over the militia of Connecticut was transferred from Phips to Fletcher, who visiting the colony declared it to be

a republic, enemies of the Church of England and of monarchs ${ }^{7}, \ldots$ separated from Church and Crown of England allowing no appeals from their courts, and no force to the laws of England. Some of the wisest have said that, not being permitted to vote for Members of Parliament, they are not liable to their laws ${ }^{8}$.

They refused obedience to Fletcher's commission over the militia, and he thereupon advised a writ of quo warranto to be made out against their charter: the irregularities being so great

1 Bill drawing up a scheme of Government for Pennsylvania, C.C. I696-7, 168 .

2 Markham to Fletcher, $i b .27$ (xi).

3 Commander-in-Chief of New York to the King and Queen, C.C. I689-92, r69r.

4 'Some objections against the pretended government of Connecticut,' 2b. 2477 .

5 Fletcher to Nottingham, C.C. I693-6, 178.

- Gershom Bulkeley to Governor Fletcher, $i b .245$.

- Fletcher to Nottingham, ib. 603 .

${ }^{8}$ Fletcher to [Blathwayt?], ib. 649. 
that they would not defend it ${ }^{1}$. The affairs of Connecticut were however allowed to drift.

Meanwhile Fletcher was finding opposition in New York. In February, 1693, when the Leislerites condemned to imprisonment had been released, one of their number, Abraham Gouverneur, suddenly roused the old faction against Fletcher ${ }^{2}$, and escaped arrest by betaking himself to Boston, whence Phips refused to give him $\mathrm{up}^{3}$, asserting that although Gouverneur had been to blame in abusing Fletcher, he had not done anything to warrant his being handed over to New York. The pro-Leisler party also succeeded in obtaining a bill to reverse Leisler's attainder ${ }^{4}$. Another of their party Delanoy, then made extensive charges against the governor, of his 'acts of squeezing money out of public and private purses,' of corrupt appointments ('he keeps a catalogue of the people who give him presents'), of encouragement to pirates, and of the selling of acts to the people. Moreover, Delanoy proceeded, he had offended the people by insinuations of his great interest and credit at Whitehall, which would baffle any complaints against his administration, 'and this was backed by the grandeur of a coach and six horses (a pomp this place was as little used to as himself) ${ }^{5}$ '' Again in 1696, the son of Jacob Leisler joined Gouverneur in a denunciation of Fletcher, especially for his interference in elections ${ }^{6}$, and sought to justify the original revolution in New York. 'They were supported in their objections by Sir Henry Ashurst, the agent in England for Massachusetts ${ }^{7}$. The New York assembly was also in opposition. Fletcher's urgent call for $£ 4000$ was met by a final offer of $f_{1000}$, and the governor prorogued the assembly after vain remonstrance $^{8}$. In 1696 the assembly could retaliate by bringing in a force bill, limiting the governor's power to detach parties of men from the militia ${ }^{9}$.

1 Fletcher to the Board of Trade, C.C. $1693-6,672$.

2 Fletcher to Nottingham, ib. 86.

3 Phips to Nottingham, ib. 107.

${ }^{4} \mathrm{Ib} .1803$.

5 Letter of Delanoy, $i b$. 1892 .

6 Journal of Board of Trade, C.C. I696-7, 219.

Minutes of New York Council in Assembly, C.C. 1693-6, 1769.

9 Ib. 2333. 
In face of all these difficulties, the Council of Trade decided to investigate, and asked for evidence to be sent in, in support of the charges against Fletcher, and against Nicholson, who was also suffering from an epidemic of accusations ${ }^{1}$. Finding that in Fletcher's case the charges had probably some foundation of truth, the Council of Trade took advantage of the excuse to recall Fletcher and carry out some new schemes of union which had recently been devised.

\section{(c) The Southern Colonies}

\section{Andros in Virginia}

During the administrations of Fletcher in New York and Phips in Massachusetts, the affairs of Virginia were entrusted to Sir Edmund Andros. Andros, an aristocratic Protestant, had seen much service in the American colonies, first appointed by James, then Duke of York, to be governor of New York in I674. The accession of his patron to the throne brought Andros a wider sphere of government in the union of New England, where he proved himself a capable administrator, if somewhat deficient in tact, and too much inclined to insist on the meticulous enforcement of a difficult and unpopular policy. The revolution drove him from this position, but the unsupported charges against him were dismissed by the Lords of Trade ${ }^{2}$, and in 1692 Andros was appointed governor of Virginia.

The Old Dominion was quiet during William's reign. The growth of towns was steadily resisted, and to this end the Virginians would have no fixed ports, to which goods must be taken for import or export ${ }^{3}$. Partly for this reason, a difficulty was found in carrying on the institutions of government. There was 'a paucity of Councillors, and failure to attend ${ }^{4}$.' In I695, ten members of the House of Burgesses - the Virginian Lower House-were ordered into custody for default in attending the House $^{5}$. In such circumstances, it is not remarkable that the

1 C.C. $1696-7,495$.

${ }^{2}$ Order of King in Council, C.C. $x 689-92,846$.

3 Journal of Virginian House of Burgesses, C.C. I693-6, 628.

4 Nicholson to the Board of Trade, C.C. I689-92, 2075.

5 Journal of Virginian Burgesses, C.C. I693-6, 1790. 


\section{POLI'TICAL ASPECTS OF COLONIAL POLICY [CH.}

power of the governor was considerable and even steadily increasing, according to the opinion of a long, semi-official statement describing the condition of the colony in $1697^{1}$ With the influence of the crown, and the offices of a colonial PoohBah, the governor had in his own hands the bulk of authority in Virginia ${ }^{2}$; for by his power of recommending and suspending Councillors, he could exercise control over that body; whilst the appointment of sheriffs, and the less crude methods of corruption, gave him great power in the Lower House. Taxation however was destined to give the assembly its great opportunity. That the governor was not supreme the failure of Andros to send the quotas requested by New York well shewed; although it is not unworthy of notice that Virginia gave more help than many of the other colonies, certainly more than Maryland.

An event which emphasized the position of Virginia as the Royal Dominion was the foundation of the college which perpetuated the names of William and Mary. The scheme for erecting William and Mary College originated in 1691 through the efforts of James Blair, assisted by Nicholson, who at that time held the office of lieutenant-governor, prior to the arrival of Andros. The King made a grant of about $\oint_{2000}$ from the crown treasury in Virginia, and appointed certain revenues to the new foundation, whilst Nicholson also, according to Blair, laid out $£ 35^{\circ}$ of his own money in the project. He was soon superseded however, ' and another put in his place of a different spirit and temper ${ }^{3}$ '- thus wrote Blair, probably blaming Andros unjustly through personal prejudice, for the latter governor appears to have taken much interest in the erection of the college $^{4}$, which marked a notable advance from the time when, a generation previous, Governor Berkeley thanked God that the colony had no schools.

In 1700 , Virginia made the interesting experiment of re-

${ }^{1}$ Hy. Hartwell and others to Popple, C.C. $1696-7$, 1396.

2 The Governor was also Commander-in-Chief, Vice-Admiral, Lord Treasurer, Lord Chancellor, Lord Chief Justice and Bishop or ordinary (for licences, probates, inductions and ecclesiastical cases).

${ }^{3}$ C.C. $1696-7,1396$.

${ }^{4}$ Andros to the Lords of Trade, C.C. I693-6, I870, etc. 
ceiving and settling French Protestant refugees at Manikin Town a well-chosen spot not far from James City, but as the numbers of these settlers threatened to swell considerably, the council soon recommended that no more should be sent, as they were unable to tide over the winter without assistance from the Virginians ${ }^{1}$, whilst the 'poverty and disability' of the colony prevented that assistance from being very great. For the rest, Virginia during this period does not appear overflowing with that vigour generally associated with young communities. Nicholson sent home in $170 \mathrm{r}$ an interesting dispatch, in which he lamented the state of the colony, and indicated a possible line of social exclusiveness not calculated to bring true prosperity to Virginia:

Fit and proper persons for executing the several offices and employments therein, decrease. And I dare venture...to say that in twenty or thirty years time, if the Natives can't be qualified, there will be few or none in the country capable of tolerably executing the several offices and employments: for there is little or no encouragement for men of any tolerable parts to come hither. Formerly there was good convenient land to be taken up, and there were widows: had pretty good fortunes, which were encouragements. But now all or most of those good lands are taken up, and if there be any widows or maids of any fortune, the Natives for the most part get them: for they begin to have a sort of aversion to others, calling them strangers ${ }^{2}$.

By this time, a new group of administrators had assumed the charge of American governments. Fletcher, Phips and Andros had gone. Bellomont had arrived as general governor of New England, and Blakiston had inaugurated a period of placid rule in Maryland. Nicholson forms the one link between the two periods, the eight years of war and the five years of peace.

\section{Copley and Nicholson in Maryland}

The revolution of 1689 among its many results effected the removal of Lord Baltimore from the government of his proprietary colony, by reason of the charges brought against him at that time. In Maryland as in Pennsylvania William decided that it was expedient to constitute government by the crown,

1 Minutes of Virginian Council, C.C. $1700,876,1055$.

${ }^{2}$ Nicholson to the Board of Trade, C.C. I7OI, 1042. 
and Lionel Copley therefore arrived to supersede Baltimore, with a royal commission similar to that of other crown governors. Arrangements were made however by which Baltimore retained certain duties and privileges, wholly or in $\operatorname{part}^{1}$; and there now followed a prolonged quarrel between proprietor and assembly on the question of these rights. The assembly claimed that a certain one of the duties made over to the proprietor under the new scheme was levied for defence, and therefore should not go into a private purse, that henceforth fines of justice should go not to Baltimore but to the crown, and that the proprietor's demand for 'waifs, strays, wild horses, and wild hogs,' was impossible in that province or in any other newly settled country. 'By such a grant, Lord Baltimore would engross the whole stock of the country2.' Governor Copley soon decided that there would be no peace and quiet in Maryland until Baltimore's interest was redeemed by the crown ${ }^{3}$. Copley himself however would not appear the best officer to avoid friction in such a difficult position. In the short period of his rule, he involved himself in quarrels with the secretary of the colony, and with Randolph, the surveyor of customs, both of whom were, like himself, appointed by the crown ${ }^{4}$. The latter quarrel is but one of the instances in which two coordinate authorities in the English administration found themselves incapable by position or temperament of working in harmony. In this instance, Copley accuses Randolph of abusing the jurors who decided against him in official cases,

calling them base, perjured and forsworn rogues, threatening them with the pillory and loss of their ears, and he also in public aspersed and bespattered and affronted the justices themselves, basely said by him to be picked and packed by $\mathrm{me}^{5}$.

In September 1693 , however, this discord was terminated by the death of Copley, and after a short period of rule under Andros, who had a dormant commission as commander-in-chief in case

1 The Queen to the Government of Massachusetts, C.C. $1689-92,1358$.

2 Assembly of Maryland to the King, ib. 2470.

3 Copley to [Nottingham?], ib. 2472.

4 Ib. 2706; C.C. 1693-6, 263.

5 Archives of Maryland, viJ., p. 335. Toppan, Randolph, Vol. II, p. I39. 
of the death or absence of governor and lieutenant-governor ${ }^{1}$, the colony received as its new governor Francis Nicholson.

Nicholson had been lieutenant-governor of New York in the administration of Andros under James II, and had like Andros been dispossessed of the office by the revolution. He was sent back to America in I69I as lieutenant-governor of Virginia, and at the end of 1693 succeeded Copley as governor of Maryland ${ }^{2}$. Maryland in this reign had few notable events in its history, and its records, though voluminous, are concerned chiefly with minor constitutional disputes. These nevertheless shew clearly the trend of development in colonial status and aspiration. In 1695 an act was passed for erecting free schools, and was sent to England for confirmation. The attorneygeneral thereupon objected to it as containing words 'which seem to establish the Great Charter of England in Maryland ${ }^{\mathbf{3}}$,' and the act was disallowed on that ground, and also because no power over the schools was reserved to the King ${ }^{4}$. The law was then altered to make the King supreme patron, with power of appointing some of the trustees, and it was decided that the schools be called by King William's name ${ }^{5}$. The following year the Burgesses proposed the closing of the King's offices during the sessions of their assembly, since clerks were obliged to go through the place of meeting to reach these offices. Governor Nicholson characterizing this suggestion as 'an infringement of Magna Carta,' threatened the Burgesses with dissolution, and proposed a compromise,

and the better to incite the House to the observance thereof, his Excellency was pleased to present to Mr Speaker (for the perusal of the House) a sermon preached by the present Archbishop of Canterbury of doing good for posterity, and then told them he prorogued them till the 6th inst. (the next day) ${ }^{6}$.

Another act of the Burgesses was to prefer charges against the late Governor Copley, of applying to his own use certain parts

1 C.C. $x 693-6,585,637$.

2 For biography of Nicholson see Archives of Maryland, xx, Preface.

3 Attorney-General to the Lords of Trade, C.C. I693-6, 2190.

4 Order of King in Council, C.C. I693-6, 2230.

5 Journal of Maryland House of Burgesses, C.C. I696-7, 67.

6 Minutes of Maryland Council in Assembly, C.C. I693-6, 2363. 
of the revenue raised for munitions of war, and to demand that these moneys be refunded from his estate. The little storm passed however with the promise of future safeguards ${ }^{1}$. Another constitutional point raised by the colony was whether a priest could sit in the House of Burgesses, the importance of this case lying in the fact that the only ground for refusing admittance to the cleric in question was the inability of men in holy orders to sit in the English House of Commons. Again in 1697 the clerk to the assembly was arrested on the governor's warrant, this act the house 'conceived to be a great breach of privilege ${ }^{2}$,' again applying English precedents, whilst in the same year the attorney-general had to protest against the opinion held in Maryland that all laws and statutes of England were in force where those of Maryland were silent ${ }^{3}$. It appears therefore from these incidents that, while there were in the colonies traces of a desire to escape those English fetters which had irked the pilgrims of earlier decades, there were yet signs that the new political entities were building themselves up on the traditions of the past. The divergence of thought, which was even at this time separating the colonies from the mother country, was based, not on the dissimilarity from the old of new states which had cut themselves off from it, but on a similarity of thought and of institutions which increased with the natural growth of the new states.

In $\mathrm{x} 698$ Nicholson was brought to face the usual accusations which arose against colonial governors. In his case the principal charges were that he intercepted letters, seized estates, granted special commissions to spiritual courts, and 'established Annapolis in an inconvenient place 4.' These were followed by others, preferred by the same accuser, one Slye: that he made his chaplain walk bareheaded before him to church, that he kicked an assemblyman out of church during the Litany, that he received the Sacrament in military style; and usually made his chaplain wait from ten to twelve hours, so that morning prayer was often said in the evening. Then came charges of Popish

\footnotetext{
1 C.C. $1696-7,75-77$.

$2 \mathrm{Ib} .223$.

3 Attorney-General to the Board of Trade, $i b$. I270.

${ }^{4}$ Minutes of Maryland Council, C.C. $1697-8$, I66.
} 
practices, charges against morality, and of avoiding expressions of loyalty to the King1. These accusations are of some interest in judging the sentiments of Marylanders at this time, but if the character of the accusers is to establish their truth, they are probably all false. In December 1696, evidence against Nicholson had been invited by the Board of Trade ${ }^{2}$, but the result can hardly have been condemnatory, since on the resignation of Andros now an old man, in May r698, Nicholson was appointed to succeed him as governor of Virginia ${ }^{3}$. He was succeeded in Maryland by Nathaniel Blakiston ${ }^{4}$, but did not shake the dust of that colony from his feet until he had expressed his feelings with freedom:

I think some have endeavoured to raise a rebellion, or at least have made very great disturbances....Some were very willing that the King should deliver them from popery and slavery, and protect them in time of war... but now they are not satisfied with his government, because it curbs in their former atheistical base, and vicious way of living, and debars them of their darling illegal trade.

$\mathrm{He}$ added that agitation for the restoration of the proprietary government was being carried on by the disaffected, to accomplish that independence which they were conscious of having lost ${ }^{5}$. For the last few years of the reign, the legislation was concerned with the establishment of the Church of England in Maryland, and the payment of ministers on a special scheme, since the English practice of tithes was impossible. Blakiston appears to have carried on the tradition of efficiency established by Nicholson, as he was later included in the small but select group of governors who could be trusted to exercise discretion ${ }^{6}$.

\section{(d) The Period of Bellomont \\ Union of New England}

While the affairs of the southern colonies were continuing on their placid course, New England was faced with important

${ }^{1}$ C.C. $1697-8,508$.

2 C.C. $1696-7,495$.

3 Secretary Vernon to the Board of Trade, C.C. ${ }^{2697-8,528 .}$

4 $I b .679$. ${ }^{5}$ Nicholson to the Board of Trade, $i b .760$.

${ }^{6}$ Board of Trade recommendation and Order in Council, C.C. I700, 29-30. 


\section{8 POLITICAL ASPECTS OF COLONIAL POLICY [ $\mathrm{cH}$.}

changes. In 1697 , the Board of Trade had presented a report on colonial union, in which they embodied the chief problems connected with that question, and suggested a solution ${ }^{1}$. The chief proposition, according to the report, was the union of Massachusetts, New York and New Hampshire under one civil governor, and the addition of Connecticut and Rhode Island for military purposes only. Of the colonies concerned, Connecticut objected even to military union, under a governor who had power to demand men, as grievous and a breach of their charter. New Hampshire-or rather Allen (whose outlook was that of the land interest) and the government-objected to union with Massachusetts, on the ground that such union would increase only the charge, not the strength, of New Hampshire, owing to the different conditions of defence in the two geographical areas. The Agents for New York opposed the scheme, on the ground that the colonies were far apart and rivals in trade, and urged the hardship of New York being inferior to Boston for purposes of government, 'or for the Governor's salary, which is paid by the people, to be spent elsewhere than in New York.' 'The report, after quoting these objections, stated their further opinion that different forms of government in the various colonies rendered impracticable any union except under such a military head, and that the regulations of I694 about quotas for defence had been so little complied with that it required the exercise of a more vigorous power than had yet been used to produce the desired effect. The council therefore recommended that a governor be appointed over Massachusetts, New York and New Hampshire, with the powers of Captain-General of all the forces in Connecticut, Rhode Island and the Jerseys, that his chief residence should be at New York during the war, but that he should be free to move from time to time to Boston, leaving a lieutenantgovernor at either place during his absence. 'We think that hereby the General Assemblies of the colonies may be made to understand their own interests, and to enact such laws as will enable your Captain-General to execute his commissions ${ }^{2}$.'

1 Board of Trade to the King, C.C. $1696-7,762$.

2 $I b .762$. 
Following this report the Earl of Bellomont was appointed to the new governorship ${ }^{1}$; and at the same time the attorneygeneral received orders from the King to inspect the charters of Connecticut and Rhode Island in relation to government and power of constituting a governor ${ }^{2}$.

\section{Bellomont}

Bellomont was an Irish peer: and his arrival as governor of the northern colonies marks the beginning of an interesting three years. His dispatches are full of life, and yet his downright character seems to have been not without great ability and tact. Moreover, even his enemies could find little to accuse him of except in policy ${ }^{3}$. The corruption of the period touched him so little that he died a poorer man for his three years' rule; and left his family in extreme necessity ${ }^{4}$.

\section{In New York}

From the first, the new governor denounced his predecessor's administration, and entered too readily into the factions which had divided New York since the revolution. In his first dispatch Bellomont shews his attitude towards the Leislerites by the statement that the first occasion of the divisions was the execution of those who had been most forward in the happy revolution. He charged several of the council with abetting breaches of the Navigation Laws and proceeded to suspend these members, he took bond from Fletcher to answer for some moneys that the late governor was alleged to have embezzled and converted to his own use, and he further charged Fletcher with encouraging piracy ${ }^{5}$ :

'I find,' he declared, 'that my predecessor has left me a divided people, an empty treasury, a few miserable, naked, half-starved

1 Shrewsbury to the Board of Trade, C.C. I696-7, 804.

2 Order of King in Council, ib. 764 .

${ }^{3}$ Hughes, History of the Fesuits in N. America, throws out many unproved aspersions and charges of corruption against Bellomont (Mr Hughes' chief objection seems to consist in the fact that Bellomont was a 'Lord'). In any case, some corroboration is needed before the verdict of historians is thus shattered, and the ordinary sources of history for the period do not yield this.

4 See below, p. 127.

5 Bellomont to the Board of Trade, C.C. $1697-8,472-3$. 
soldiers-not half the number the King allowed and paid for-in a word the whole government out of frame... ${ }^{1}$. There is much discontent among those who have been prevented by foul play from sitting in the House....He [Fletcher] went so far as to publish a book...to revive the old story of Leisler ${ }^{2}$.

Thus the charges mounted up: Fletcher had received $£ 400$ for passing an act prejudicial to New York City, and so forth ${ }^{3}$. In two respects it appears fairly clear that Fletcher's conduct had been unsatisfactory, in granting land extravagantly to a few landowners - the whole province was granted to about thirty owners - he had prevented the adequate defence of the frontier, and the troops guarding that frontier had been neglected, and were found by Bellomont to be starving. How far this state of things was the fault of Fletcher, and how far it was due to the lack of money voted, the evidence does not decide.

Since Bellomont thus took up a pro-Leisler attitude, complaints from the other side followed naturally-from merchants, who deplored the Leislerite influence encouraged by the governor and resulting, they asserted, in the appointment of unsuitable officers ${ }^{4}$. Moreover Bellomont was in 1699 kept for six months without news or orders from home, and this neglect gave the 'Jacobite party,' as he called them, ground for giving out that he was in disgrace 5 . Bellomont himself denied the charge of favouring either party. Early in 1699 he decided to call an assembly 'to cure the present unhappy differences among the people ${ }^{6}$.' The anti-Leislerites went to the poll with the claim of being the 'English' party, but Bellomont ridiculed this claim:

three of the four candidates they set up were as mere Dutch as any in this town...Johannes van Kipp, Rip van Dam, and Jacobus van Cortlandt. The names speak Dutch, and the men can scarce speak English ${ }^{7}$....I discourage all I can these distinctions of Dutch and English, and I tell 'em that the only Englishmen are those who live in obedience to the laws of England.... The execution of Leisler and

1 Journal of New York House of Representatives, C.C. $1697-8,475$

2 Bellomont to the Board of Trade, $i b .502$.

$3 \mathrm{Ib} .593$.

4 Various merchants to the Board of Trade, C.C. $1699,90,169$.

${ }^{5}$ Bellomont to the Board of Trade, $i b$. I 16 .

'Minutes of New York Council, $i b$. $4 \mathbf{I}$.

: Bellomont to the Board of Trade, ib. 317 . 
Milborne was as violent, arbitrary and cruel a proceeding as in any age under an English government ${ }^{1}$,

and Bellomont spoke with scorn of Nicholls, Bayard, Brooke ' and the rest of the Bloodhounds ${ }^{2}$.' The governor seemed certainly to have some justification now for his attitude, whether or not the party principles were the same under Fletcher; for the anti-Leislerites sought to win the elections on the cry of doing away with the customs; and in the assembly they moved for the omission of the word 'Happy' in references to the late revolution ${ }^{3}$. This was the state of parties in New York, the heritage of the revolution. Meanwhile Fletcher's case had come before the Lords of Trade; and he was found guilty of actions contrary to his duty in connection with the trade laws and piracy although with the consent of the council; whilst his land policy of exorbitant grants was also condemned. The general verdict was that he had shewn lack of caution, and the charges of neglecting defence were not considered proved ${ }^{4}$.

Bellomont now proceeded to revoke Fletcher's grants of land as far as possible, with the order from the Lords Justices. Having this order, he said,

I value not the resentment of a few undeserving men, being sure that 'tis not for the interest of the Crown or the Provinces that three parts out of four of the lands should be in the hands of ten or eleven men. Therefore am I for abolishing the rest of the Palatinates (for such vast tracts deserve no less a name) the next Session, if I have strength. But indeed I can promise nothing without a good lawyer to be Chief judge, and a good active lawyer to be Attorney-General. I have stood single on my own legs in all these difficulties, and 'tis impossible for me always to bear the burthen of business. The Bill for vacating grants begun with us at the Council Board, and we sent it down to the Lower House, and there they added a clause for depriving $\mathrm{Mr}$ Dellius of his benefice at Albany, so that we were obliged to pass that clause as part of the Bill, or we must have lost the Bill, and I thought it better to loose a wicked clergyman than good Bill ${ }^{5}$.

1 C.C. $1699,384$.

$2 \mathrm{Ib}$.

3 Bellomont to the Board of Trade, $i b .3^{8}+$.

4 Board of Trade to the King, ib. 167.

5 Bellomont to the Board of Trade, ib. 467 . 
The governor in his zeal for reform even went to the length of reversing one of Fletcher's judgments-a dangerous precedent ${ }^{1}$.

To Bellomont also historians are indebted for a classic description of the legal officers in the colonies:

The Chief Justice...is no sort of lawyer, having been bred a soldier. $\mathrm{He}$ is a man of sense, and a more gentlemanlike man than any I have seen in this province, but that does not make him a lawyer.... He lives fourscore miles off, and comes but twice a year to this town, at the time of the Supreme Court's sitting, just to earn his salary.... As to the men that call themselves lawyers here and practise at the Bar, they are almost all under such a scandalous character that it would grieve a man to see our noble English laws so miserably mangled and prophaned. I do not find that a man of 'em ever arrived at being an Attorney in England. So far from being barristers, one of them was a dancing-master, another a glover by trade; a third was condemned to be hanged in Scotland for burning the Bible and for blasphemy...and there are two or three more as bad as the rest....They are all, except one or two, violent enemies to the Government ${ }^{2}$.

In face of this report, the King decided to send a Chief Justice and an attorney-general from England, with fixed salaries paid from home ${ }^{3}$.

\section{Massachusetts}

In Massachusetts it was evident that the old charter struggle was by no means dead and in $170 \mathrm{O}$ the colony was petitioning for power to choose its own governor ${ }^{4}$. In many ways attempts to evade English constitutional control revealed themselves, although, as has been pointed out, allowance must always be made for the difficulty of communication, which sometimes gave the impression of deliberate evasion to actions that were designed merely to facilitate public business ${ }^{5}$. Of two Massachusetts Acts repealed at this time in England, one incorporating Harvard College, did not give power to the King to appoint visitors and was disallowed on that ground; the other directed that all cases should be tried by jury, thus contradicting the provisions made, under the Act for Preventing Frauds ${ }^{6}$, for the

1 C.C. $1699,467,317$.

3 Order of King in Council, C.C. I699, 1062.

4 Council in Assembly of Massachusetts, C.C. $170 I, 586$.

5 See above, pp. IоI-2.

2 Ib. 134 .

6 See below, p. 153 . 
trial of offenders, against the Navigation Laws. Moreover the practice was discovered of grouping acts relating to different subjects in such a way as to ensure the passage of all; and also - a more dangerous principle-the assembly was found to be evading the disallowance of their acts by passing them for short periods, and renewing them, if or before they were disallowed, in the same or similar terms ${ }^{1}$. Bellomont was instructed to prevent this ${ }^{2}$. In the same year, Massachusetts sought to obtain final judgments in the colony, and to prevent the right of appeal to England by customs officers, in disputed cases of trade-an attempt the success of which would threaten to undermine the entire navigation system. The custom officers' right was however confirmed, with a caution against its abuse.

As to the laws of England, they abhor the very thought of them; and Acts of Parliament they look upon to be only obligatory when the Province is particularly named.....Little better is to be expected till Parliament think fit to take away their charter, and His Majesty shall...send judges of his own....Some declare publicly that they will oppose the landing of Col. Dudley (the governor appointed after Bellomont's death).

Thus wrote the commissioner sent out from England in connection with new schemes for suppressing illegal trade ${ }^{3}$. He also noted an interesting change of character in the colony: 'Here is a great many young men educated at the College in Cambridge, who differ much in their principles from their parents'-perhaps an indication of relaxation in the rigid Puritan standards of Boston.

\section{New Hampshire}

Bellomont had to deal not only with New York and Massachusetts, but with the lesser governments over which his authority extended. Of these, New Hampshire had been in an unsettled state ever since the revolution ${ }^{4}$. Its four towns had

1 There is a parallel case in Maryland $\mathbf{r} 70 \mathrm{I}$ of a religious law 'having been several times repealed here [in England] and as oft reenacted in Maryland and above $f, 30,000$ levied which ought not to have been.' (C.C. I 7OI, 5I.)

${ }^{2}$ C.C. $1699,73$.

3 George Larkin to the Board of Trade, C.C. I7OT, 945.

- For the history of New Hampshire in this period see Sanborn, New Hampshire in American Commonwealth Series. 
not succeeded in agreeing upon a constitution at the critical moment of revolt, and as a result, Samuel Allen, who had purchased as he supposed vast claims to land in the province, was nominated governor, and in turn appointed his son-in-law, Usher, lieutenant-governor, the latter having also an interest in preserving the proprietary system, owing to his claims over land in Maine. Usher however was unable to preserve unity in the colony, and was constantly complaining of the people's attitude, and of that of the neighbouring colonies, especially Massachusetts, who accepted certain responsibility over defence in New Hampshire. In I693, Usher left his government as he could do nothing through fear of the people ${ }^{1}$. In 1696 a new lieutenant-governor arrived, one Partridge, about whose appointment there is some uncertainty, but for whom the inhabitants had petitioned. The colony now divided into the parties of Partridge (and the council) and Usher; but the former succeeded in restoring some measure of peace ${ }^{2}$, Usher protesting throughout that no real settlement was being made: "If these actions be right, let them be excused, if not, dealt with according to their demerit ${ }^{3}$ ' was his plea. Still however affairs were allowed to take their course without interference from home, and in October 1698 the proprietor arrived in person to bring order into the province. Partridge refused to give way, and continued to carry on government in spite of Allen. Finally in I699 Bellomont arrived to settle affairs ${ }^{4}$. He decided that the disturbances were mainly due to Allen's vast and uncertain claims over the land, and to Usher's 'unhappy choleric temper,' although the latter had meant well. Bellomont regularized Partridge's administration, and proposed a settlement of the difficulties by paying Allen $\AA_{25}$ (at which price he bought his claims to a vague three millions) and urged that any attempt by Allen to enforce these claims should be resisted by force ${ }^{5}$. Allen however preferred the verdict of a jury on his rights, and

1 John Usher to the Board of Trade, C.C. $1693^{-6,666 .}$

2 Council and Assembly of New Hampshire to the Board of Trade, C.C. $1697-8,215$.

3 Usher to the Board of 'Trade, $i b, 324$.

4 Bellomont to the Board of Trade, C.C. $1699,769$.

5 C.C. I700, 580. 
in 1700 this verdict was given against him in a test case. Allen appealed against this verdict, but the New Hampshire judges, following the precedent of Massachusetts, refused to allow an appeal to the King. This decision was resented by William, and the Board of Trade wrote to Bellomont accordingly:

This declining to admit appeals to His Majesty in Council is a matter which you ought very carefully to watch against in all your governments. It is an humour that prevails so much in proprieties and charter governments, and the independence they thirst after is now so notorious that it has been thought fit those considerations, together with the objections against those colonies, should be laid before Parliament. A Bill has therefore been brought into the House of Lords for uniting the right of government in these colonies to the Crown ${ }^{1}$;

and on the recommendation of the Board of Trade, Allen's appeal was admitted ${ }^{2}$.

While exploring the documents of New Hampshire, Bellomont discovered a contract between Allen and William Blathwayt, the influential colonial administrator and member of the Board of Trade, by which contract Blathwayt obtained an interest in the proprietorship of that colony ${ }^{3}$. 'By this bargain,' commented Bellomont, "it is plain who sold the lands in New York to Fletcher'-meaning presumably that Blathwayt was responsible for the instructions which enabled Fletcher to make his extravagant grants of land- 'he has made a milch cow of 'em for many years together.' It is also almost certainly Blathwayt that Bellomont is hinting at when he says sarcastically:

The King will have an eternal obligation to that man that advised the reduction of the Four Companies, and that has compassed their being so ill paid, for I strongly suspect both these arrows have come out of the same quiver ${ }^{4}$.

In this connection, it is noteworthy that among the numerous presents of money voted in 1694 by Massachusetts to agents and others who had served the colony, there figures one item of ' $f$ roo to William Blathwayt,' thus indicating that the latter

1 Sanborn, op. cit. Chap. vir. This passage is quoted from that authority. $I$ have been unable to verify the original.

${ }^{2}$ Board of Trade to the King, C.C. I7or, 365-6.

3 Bellomont to Secretary Vernon, C.C. I70o, 582.

4 Bellomont to the Board of Trade, ib. 666. 
had in some way served the interests of Massachusetts, at a time when that colony was still struggling for its old charter rights ${ }^{1}$.

\section{Rhode Island}

Bellomont was also commissioned to examine the State of Rhode Island ${ }^{2}$. This colony had been governed since the revolution on the basis of its former charter, which had been surrendered to James II on a writ of quo warranto. The new government found difficulties in its way, and was not easy on the rights of its position. In $169 \mathrm{I}$ its representatives wrote that they had no orders from the King; 'we do not know under what government we are tho' our charter is neither condemned nor taken from us ${ }^{3}$ '. 'The colony nevertheless took upon itself to resist Phips' commission over its militia ${ }^{4}$, with the complaint that he disregarded their nominations for officers and appointed those to whom the 'Governor and Company' objected $^{5}$. In I694, a legal opinion was given that the King might appoint a commander-in-chief in time of urgency, but that local command rested with the province, thus apparently the resumed charter was tacitly acknowledged ${ }^{6}$. The charter government however seemed to fail in the main duties of a government. According to Randolph the governor, Carr, was an illiterate man; the place harboured pirates ${ }^{7}$; Quakers and Anabaptists managed the colony; neither judges, juries or witnesses were under any obligation; and the condition was sufficiently bad to induce several men of good estate to offer $£ 500$ towards the support of a royal governor ${ }^{8}$. A commission as Judge of Admiralty had been granted by the English authorities to one Peleg Sanford, but Governor Clarke had appropriated this commission to himself, as it conflicted with the ordinary system of justice ${ }^{9}$. Bellomont arrived to investigate,

\footnotetext{
C.C. $1693-6$. 1103.

2 Order of King in Council, C.C. $1699,17$.

3 Governor of Rhode Island to Stoughton, C.C. $1689-92,1457$.

4 Phips to Nottingham, C.C. I693-6, 108.

${ }_{5}$ Address from Rhode Island to the King and Queen, $i b .524$.

6 Attorney-General and Solicitor-General to the King and Queen, ib. 999.

7 Randolph's papers, C.C. I696-7, 1 20.

8 Randolph to the Board of Trade, C.C. $1697-8,52 \mathrm{x}$.

${ }^{9}$ For this and other details see Rickman, Rhode Island, in American Commonwealth Series.
} 
and decided that the Rhode Islanders were 'the most irregular and illegal in their administration that ever any English government was'.' Their main delinquencies consisted in the method of calling an assembly, the position of the governor, the election of military officers by the soldiers, restricted elections for the assembly, which also sat wrongfully as a court of judicature, illegal raising of taxes, non-recording of acts, and many technical irregularities ${ }^{2}$. In short, the government seems to have been purely extempore, without reference to the colony's rightful status or its relations with England.

In $170 x$ the death of Bellomont removed the ablest colonial governor in America during William's reign. 'He wore out his spirits and put an end to his life by the fatigue he hourly underwent to serve him [the King] in this far country.' His family 'were made poorer by this Government which was given as a mark of His Majesty's favour.' Thus wrote Lady Bellomont ${ }^{3}$. The late governor did not even leave a sufficiency for the support of his family or for the discharge of his funeral expenses without private credit, having spent considerable sums on a ship laden with timber, which he sent home to the Admiralty in connection with his schemes for producing naval stores in New England. The New York Council, in asking for a new governor, petitioned for one having 'the same honourable principles and zeal for His Majesty's interest and the good of the inhabitants as the Earl of Bellomont, whose loss we can never enough bewail 4.' And the council realized the debt they owed to the late governor when, after his death, they were obliged to pledge their private credit for the maintenance of garrisons ${ }^{5}$. After Bellomont's death, the factions of New York fall little short of completing the circle of fluctuations since the revolution. A bill for refunding part of Leisler's expenses was brought in, and no objections were raised to it; but for accidental reasons it did not become law ${ }^{6}$. The Leislerite party in fact gained such

1 Bellomont to Popple, C.C. I699, 929.

2 Bellomont to the Board of Trade, $i b$. 1002.

3 Lady Bellomont to Secretary Vernon, C.C. I70 T, 769.

4 New York Council to Secretary Vernon, $i b .2$ I 2.

5 Ib. 230.

${ }^{6}$ Minutes of Council in Assembly, New York, ib. 960. 
strength during the vacancy of the governorship that Bayard, one of Fletcher's principal councillors, was committed for high treason $^{1}$, and was only saved by the opportune arrival of the new governor, Lord Cornbury, whose arrival as governor of New York had been delayed by certain negotiations concerning army contracts and pay-negotiations which proclaimed Cornbury to be an unworthy successor of Bellomont ${ }^{2}$.

\section{The proprietary governments}

The closing years of William's reign saw an added interest taken in the proprietary governments. Of these, Maryland affairs had been settled with comparative success; Carolina was hardly of sufficient importance as yet to cause much cogitation, but Pennsylvania and New Jersey came into temporary prominence. New Jersey, divided and subdivided, was in the hands of various proprietors, under groupings that tend to baffle; but the eastern part was the property of several English gentlemen, who aroused the attention of the home government by their desire to make Perth Amboy, their trading port, free to commerce. The New York collector of customs protested that all goods coming into the Jerseys must be entered at New York, in accordance with the long-established practice ${ }^{3}$; and the law officers of the crown confirmed this by finding that the Duke of York had no power to create ports, and therefore could not grant such right to the Jersey proprietors ${ }^{4}$. The council of Trade and the royal order therefore decided against Perth Amboy ${ }^{5}$. The proprietors however pressed their case, offering to raise the same duties as at New York, and to give half the proceeds to New York fortifications ${ }^{6}$; and finally they asked for the trial of their cause at Westminster Hall ${ }^{7}$. The Board of Trade recommended this trial, and cunningly combined with the question at issue the proprietors' title to the government,

1 C.C. I702, 41 .

$2 \mathrm{Mr}$ Champante to the Board of 'Trade, C.C. I70I, 1058.

3 Report of Commissioners of Customs, C.C. I696-7, 1308.

4 Popple to the law officers, $i b .1367$.

5 Board of Trade to the Lords Justices and Order in Council, C.C. $1697-8,2,69$.

B Board of Trade Journal, C.C. I699, $216 . \quad 7$ Ib. 164. 
'a matter in which they are very tender ${ }^{1}$ '' The proprietors now offered to surrender their rights of government, on condition of retaining their lands and the quit-rents on them; and of Perth Amboy becoming a free port; whilst West Jersey, for the most part under the same proprietors, expressed surprise at the titles being questioned, and pointed out how grievous would be annexation to New York ${ }^{2}$. While delaying the trial, thus altered from their original plan, as much as possible, the proprietors sought to strengthen their position by asking the royal approbation for the new governor of West New Jersey; but the Board of Trade saw through the attempt, and replied that their title must first be established ${ }^{3}$. It was evidently expected that the title would be found invalid ${ }^{4}$; but contrary to anticipation the proprietors won their case, their claims were justified, and Perth Amboy became a free port ${ }^{5}$. Meanwhile New Jersey itself was in a troubled state. The royal collector was threatened in the execution of his duty by 'twenty persons disguised, armed with clubs, pallizadoes and other weapons of a prodigious bigness,' and the goods seized by him forcibly removed ${ }^{6}$. Some planters were advancing the opinion that the King's right to the American countries discovered by English subjects was only notional and arbitrary, and that the Indian natives were the absolute independent owners, and had the sole disposal of lands ${ }^{7}$. The proprietors used these opinions to strengthen their own position, by identifying such speakers with those who were petitioning against proprietary government in Jersey; but all their efforts were to gain good terms for the surrender of their rights, on which they appear to have been determined ${ }^{8}$.

Meanwhile Pennsylvania was the subject of considerable correspondence. Penn arrived in $\mathbf{1 6 9 9}$, and his first acts were such as to satisfy even Colonel Quary, the judge of Admiralty

1 Board of Trade to Beliomont, C.C. $1699,726$.

2 Proprietors of West Jersey to the Board of Trade, $i b .595$.

3 Board of Trade to Bellomont, ib. 726.

4 Board of Trade to the King, C.C. $1700,72$.

5 Bellomont to the Board of Trade, ib. 845 .

6 Collector at Perth Amboy to Commissioners of Customs, C.C. I699, $88_{5}$, ii.

7 Proprietors of East Jersey to the Board of Trade, C.C. 1700,985 .

$8 \mathrm{Ib}$. 
and the inveterate denouncer of Quaker illegalities ${ }^{1}$. But this satisfaction was short-lived. In the same year, Quary was again complaining, this time including Penn in his grievance:

'Now that he has made all things easy and smooth at home, he runs counter to all'....although 'he would not have appeared so barefaced had not his Quaker friends forced him to it by keeping the purse strings close.'

Penn had even taken away the Courts of Admiralty, erected to suppress piracy and illegal trade ${ }^{2}$, and appointed his own officers to exercise that function ${ }^{3}$. Another grievance, concerning the defence of the frontier, was that non-Quakers, although in the majority, were not allowed to take up arms, because none of the magistrates was a member of the Church of England ${ }^{4}$.

In I70I, the Board of Trade recommended the resumption of proprietary governments, on the ground of irregularities daily increasing, to the prejudice of trade, revenue and the other plantations'; and because they had not answered the design for which privileges were given. They were refuges for pirates, they neglected defence and delayed appeals to England; and moreover they tended to encourage

woollen and other manufactures proper to England instead of applying their thoughts and endeavours to the production of such commodities as are fit to be encouraged in these parts, according to the true design and intention of such settlements ${ }^{5}$.

A Bill was therefore brought before the Lords ${ }^{6}$, 'for re-uniting to the Crown the government of several colonies in America'; but it was shelved. The Board of Trade did all that its powers would permit, sending letters to Nicholson and Blakiston, and later to Cornbury, Dudley and Randolph, to send over proofs of misdemeanours of proprietary governments and governors in their neighbourhood ${ }^{7}$. Nicholson proposed that, if such a bill did not pass, 'the late revolution in the Bahama Islands

1 Penn to Vernon; and Quary to Vernon, C.C. $1700,156,188$.

2 See below, p. 154.

3 Colonel Quary to the Admiralty, C.C. 1700,932 (i) and (ix).

4 Vestrymen of Christchurch, Philadelphia, to the Board of Trade, C.C. ITOI, IOI.

5 Board of Trade to the King, $i b .286$.

6 Journal of the Board of Trade, $i b .530$.

7 Board of Trade Journal, $i b .645$ 
may be countenanced, and then the like thing may happen to most of the other proprietary and charter governments ${ }^{1}$.' Penn of course protested against the Act. Basing his opposition on denial of the charges, and on the sacredness of property, he concluded:

Nor is it the powers of government alone that here is contended for; our liberties and the first inducements to undertake so hazardous and difficult an enterprise are struck at by that Bill, and must inevitably fall if carried on upon the bottom it now stands.... I have been a constant drudge to all your directions, and a King's governor in all things but a salary ${ }^{2}$.

The Bill, however, brought forward in $\mathbf{1 7 0 2}$, did not pass--for lack of time; and Penn's fears were not realized. But early in the year, the surrender of the charters of East and West New Jersey was received ${ }^{3}$.

Meanwhile, almost without comment, the united government of New England had lapsed with Bellomont's death, and the system of separate governorships returned, Lord Cornbury going out to New York, and Colonel Joseph Dudley to Massachusetts.

\section{(e) The West Indian Governments}

The three main governments in the West Indies-Jamaica, Barbados, and the Leeward Islands-were throughout this period the scene of protracted struggles between governors (and other royal officials) and their assemblies, which invariably refused to cooperate heartily in the working of the Navigation system of restriction and privilege. The governors therefore were often tempted to make matters easier for themselves by winning over the leading men of the island by means of that influence which a governor always had at his disposal, and which was not always within the scope of the honourable conduct of his office. At the same time the officials not appointed directly from home had even less incentive to court unpopularity by associating themselves too closely with the cause of a distant but

1 Nicholson to the Board of Trade, C.C. I7OI, 104I.

${ }^{2}$ Penn to the Board of Trade, $i b .791$.

3 Order of King in Council, C.C. I7O2, 347. 
interfering government. The problem of this situation was constantly before the governors appointed in William III's reign; and as in many cases they were men of outstanding character and ability, their methods of dealing with the difficulty, and their criticisms of governmental policy and of colonial administration, are of considerable importance in analysing the problem.

\section{The Governorship of the elder Codrington}

The principal achievements recorded in the first half of William's reign are due to Codrington's efforts in the Leeward Islands. Codrington was a rich planter of Antigua, but a soldier as well; and, taking over the government soon after war was declared against France, he threw himself wholeheartedly into the task of organization among the divided little communities of the English West Indies. The government of the Leeward Islands comprised the islands of Antigua, Nevis, Montserrat and the English half of St Kitts, each of which had its own lieutenant-governor (except Antigua, where the general governor resided), council and assembly. There was moreover a General Assembly, originated about 1674 , but not gaining legislative power until seven or eight years later, to which two representatives were sent from each island's council and assembly. 'This body (and the system of unified control) was not popular, and fell into disuse early in the eighteenth century, the period of the two Codringtons being its time of greatest activity $^{1}$. There was an ever-present tendency for the islands to assert themselves against the general authority of the governor. In 1689 Nevis refused to obey Codrington's orders to transport the St Kitts refugees from Nevis to Montserrat, where they would have the chance of a better livelihood ${ }^{2}$; and in 1696 the same assembly objected to the instructions given to their lieutenant-governor, by which the island was deprived of the power to pass laws by Governor, council and assembly ${ }^{3}$. Antigua also protested in 1698 against the undue position of the Governor-in-Chief, who performed only the duties of a private

1 For these details and general survey of previous history see Higham, Leeward Islands, 1660-89.

2 Codrington to the Board of Trade, C.C. $1689-92,548$.

3 Minutes of Nevis Assembly, C.C. I696-7, I I 5 . 


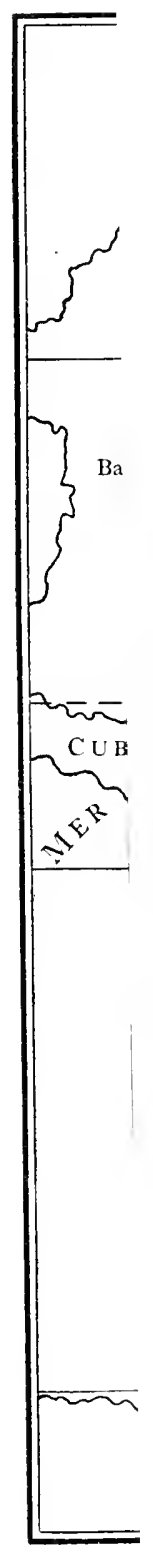


$$
\text { . }
$$ 
governor, received too large an allowance, and by means of the general assembly could resist legitimate demands made unanimously by one of the islands. They sought a remedy in a larger representation from the islands in the general assembly, and in greater powers, with armed force, for the lieutenant-governors, the Governor-in-Chief to command only the naval force besides the soldiers of his own island. This scheme, it was pointed out, would result in better information for the Board of 'Trade'. For the purposes of the war with France, however, Codrington succeeded in overcoming the tendency to separation within his own government, and even recommended that the Leeward Islands should be annexed to the Kingdom of England, with representation in the English Parliament ${ }^{2}$.

\section{Constitutional questions}

The small islands themselves in Codrington's government had their constitutional questions, causing much agitation, and generally following the line of development on which the English constitution had developed. Antigua, in reply to a protest from the Governor against certain words spoken in the assembly, asserted that 'to be called to account for words spoken in the House was a breach of privilege ${ }^{3}$.' Nevis was divided by a quarrel between council and assembly, the latter claiming the right to decide whether members were duly elected, the council refusing to swear such members as it believed not to be qualified ${ }^{4}$. The assembly retaliated by refusing to participate in a joint commission from the two bodies to carry on the war, until its members should be duly sworn. Shortly after, they presented a complaint to the governor about the conduct of the war; and, upon the council's refusal to reply, the assembly resolved itself into a committee of the whole, to meet from time to time, for the good of the country ${ }^{5}$. Montserrat, on the other hand, was constitutionally quiet, its main concern being to guard against the negroes. The typical extracts from Montserrat records deal with the appointment of patrols, who, on meeting negroes

\footnotetext{
1 Antigua Assembly to the Board of Trade, C.C. $1697-8,747$.

2 Codrington to the Board of Trade, C.C. $1689-92$, 1212.

3 Minutes of Council and Assembly of Antigua, C.C. $1696-7,43$.

4 Minutes of Nevis Assembly, ib. 87.

Ib. 216
} 
without their owner's ticket, should 'beat or slash them, and if congregated together... disperse them, pistolling and killing them if need be ${ }^{1}$.' One negro was cut to pieces for stealing nine pigs. Another had an ear cut off and his breast burned for 'having some unaccountable fresh flesh in his house ${ }^{2}$ '' While these measures shew that fear of negro insurrection was uppermost, black labour was urgently needed and on occasion negroes convicted even of murder would be preserved on payment of a heavy fine by their masters ${ }^{3}$. The population of Montserrat was in fact made up in a proportion quite different from that of the other islands, the negroes outnumbering the English by about eight to seven, whilst the Irish, who were also keenly distrusted, equalled approximately the two together ${ }^{4}$.

\section{The end of Codrington}

It is unfortunately true that Codrington, great as were his achievements, did not succeed in setting his standard of government completely above the corruption which prevailed so frequently at this period. The main accusation brought against him was that of shielding one Arthur from prosecution on the charge of speaking highly criminal words, Codrington having an interest through illicit trade in Arthur's freedom. In spite of the faults committed by his accusers and the magistrates, the Board of Trade decided that 'none of these things excuse Governor Codrington from omitting to do many things which his duty required of him ${ }^{5}$.' There were other charges of similar import, concerning Codrington's persecution of one Lucas; and in this case also his conduct was condemned. While the charges were still before the home authorities, Codrington was spared further disgrace by his death in December $1698^{6}$ - an unhappy ending to an able and not essentially corrupt administration.

\section{The governorship of the younger Codrington}

If however his death leaves a gap hard to fill in the history of West Indian politics, the choice of his successor does much

1 Minutes of Montserrat Council and Assembly, C.C. I693-6, 182.

2 Ib. 520. ${ }^{3}$ C.C. $1696-7,1375$. Higham, op. cit.

5 Board of Trade to the Lords Justices, C.C. $1697-8$, 81 7.

- President and Council of Nevis to the Board of Trade, ib. 1089. 
to compensate for this. Another Christopher Codrington, as able as his father, and more brilliant, was appointed to succeed the first as governor of the Leeward Islands. The new governor, a distinguished Oxford scholar and courtier, had, besides his literary accomplishments, a strength of character which offers a tempting parallel between his rule in the West Indies and that of Bellomont in America. He was prepared to give his best to his government; but he did not lack a shrewd common-sense, which shewed itself at the outset. Although appointed in $\mathbf{6} 699$, he refused to set out until the four years' arrears of salary due to his father were paid; and in fact he did not leave until August $1700^{1}$.

On his arrival, Codrington found the islands disturbed by several quarrels of importance. Nevis had refused to quarter the royal soldiers unless they worked with the negroes on the plantations; and Colonel Fox, the Lieutenant-General, had therefore refused to pass any acts until the island relented ${ }^{2}$. The Lieutenant-Governor of St Kitts also was making a disturbance by his expressed intention to govern by his sword and cane $^{3}$, and was made the subject of an inquiry ${ }^{4}$, which found him guilty of conduct unworthy of one in his position: the Acts of Trade were being broken; 'the noble governor would condescend to plunder even for a pound of soap, as well as shoebuckles... ${ }^{5}$ ' and was fitter to 'be a Rapparree than a Governor ${ }^{6}$.' Thus Codrington decided, and after some experience of his new position, he sent home some more interesting reflections on it. After pointing out that his salary covers only a fourth part of his expenses, he continues:

In respect of governors who come abroad to make their fortunes, as I did to understand and establish mine, Acts of Trade, Instructions, and all your Lordships' wise and good orders to them are verba et praeterea nihil... ${ }^{7}$. Governors must be put upon a very different footing before these colonies are made so serviceable to the Trade of England as they may be. Whilst governors are dependent

\footnotetext{
1 Board of Trade Journal, C.C. I700, 434, 720.

2 Colonel Fox to William Blathwayt, $i b .373$.

3 Petition of John Cole and others, $i b .658$.

4 Order of Lords Justices, $i b .773$.

5 Codrington to the Board of Trade, C.C. I7OI, 33.

${ }^{6} \mathrm{Ib}$. 112 .

? Ib. 784 .
} 
on their Assemblies, Acts of Trade will never be observed. If you knew who were the leading men in the several assemblies, you would be convinced that governors ought to have better salaries and not be permitted to take any presents from the people. Whilst they do, there will be illegal indulgences in point of Trade, justice will be bought and sold, Chancery suits protracted, and the poor oppressed...1. The colonies abroad will be then governed as they ought to be when Governors are made independent of their assemblies, and after that hanged up when they don't do their duty....If I had not an estate here I would not serve in this Government for $f_{2000}$ a year ${ }^{2}$.

Codrington is no doubt right in his remedy, but such reports as this confirmed the assumption that the interests of the colonies were different from those of the mother country, and as the latter were considered to be paramount, it naturally followed that colonial interests must not be allowed to influence governmental policy--an assumption which, once acted on, led straight to separation. Repression of local interests to serve an external government cannot last for ever.

\section{Barbados under Kendall}

In Barbados also constitutional questions of interest arose. In 1690 the assembly summoned the customs officers to answer charges of extortion. They refused to attend, and were supported in their refusal by Governor Kendall, on the ground that such affairs were no business of the assembly ${ }^{3}$. In I69I, Kendall was attacked by one Colonel Hallett, a councillor who had been required to give up certain parts of his land for the purpose of fortifications. Hallett refused to consent, 'conceiving it to be against Magna Carta that this should be done without compensation 4.' 'Two years later it was again the turn of the assembly to quarrel with the governor. The House refused to fulfil a promise that it would grant more money if required; and Kendall, to get rid of opposition, enforced a law compelling all deputies to receive the sacrament, with the result that only seventeen could take their seats as duly returned, fifteen being necessary for a quorum. Three of these seventeen were pre-

1 Codrington to the Board of Trade, C.C. I7or, 26.

$2 I b .112$.

3 Minutes of Council and Assembly of Barbados, C.C. I689-92, 1087-8.

4 Ib. 1862. 
vailed on to absent themselves, and a deadlock ensued ${ }^{1}$. Some weeks later instructions disallowing the Sacraments Act arrived from England, obtained, Kendall believed, by surreptitious means ${ }^{2}$. Throughout all these disputes, however, personal feeling does not appear to have become much embittered; and in the same month the departure of Kendall was the occasion of a vote of thanks from Council and assembly, and a present of $£ 5^{00}{ }^{3}$. Charges against him appeared of course; but they were neither serious nor effective ${ }^{4}$. Both Kendall and his successor, Russell, seem to have been sound administrators, as popular at Barbados as any governor was likely to be, and at the same time trusted by the neighbouring islands and by the home government.

\section{Russell}

Russell found the island in a poor way, as a result of the war, and public credit so bad that people would not work for it or trust it ${ }^{5}$. He too succeeded to the steady quarrel with the assembly, which was now claiming the right to approve expenditure, and had induced the Treasurer to give account to itself; whilst the necessity for a quorum still gave factious interests the means of baulking an undesirable measure. Russell however was equally determined; and on one occasion, when he required an act passed, refused to adjourn the House until its members did as he wished, with the result that fear of infection from a prevalent disease soon brought about the required consent. The assembly however took their revenge by refusing to find the governor a house where he might reside during the epidemic which had seized fourteen out of the sixteen members of his household ${ }^{6}$. Later in the same year ( 1695$)$ the assembly refused to vote provisions for the King's ships; and the governor was obliged to pledge his own credit. In this connection the Speaker boasted that 'he had opposed all governors and all governments ?.' In r696 Russell died, and the government, in

1 Kendall to the Board of Trade, C.C. $1693-6,442$.

3 Address of Council and Assembly to Kendall, ib. 528 .

4 Grievances of inhabitants against Kendall, ib. 656.

${ }^{5}$ Russell to the Board of Trade, $i b$. 1446.

2 Ib. 568 .

$7 \mathrm{Ib}$. 1930. 
spite of his attempt two years earlier to appoint a suitable successor, devolved by law upon a President, one Francis Bond, 'an aged and crazy man ${ }^{1}$.' The Council now read Russell's instructions which until his death had never come to their sight, with the result, according to their complaint, that their opinion had never been asked on such matters as the appointment of judges, for many years past, nor did they know that it was their duty to give it ${ }^{2}$.

\section{Grey}

The remaining years of William's reign are chiefly remarkable in Barbados, under Governor Grey ${ }^{3}$, for a great outcry against the administration of justice. In 1697 the Earl of Bridgwater brought to the Board of Trade a letter from the island complaining that the judges and assistants had spent more time in perusing journals, letters and waste books than in reading Coke and Littleton; and urging the appointment of lawyers approved by the law officers of England 4 . In 1700 an eloquent description of the state of justice in the American colonies, and especially in Barbados, was sent to the Board through Mr Pollexfen. According to this account ${ }^{5}$, English merchants found more security and better and more speedy justice in the most distant provinces of the Ottoman dominions than they did in some of the American colonies.

It is grown a proverb with the English merchants that if a man goes over never so honest to the Plantations, yet the very air does change him in a short time. But it is not the air; it is the universal corruption of justice.

\section{Famaica under Beeston}

In Jamaica, the third of the chief West Indian governments, the constitutional struggle was as keen as in any, and is moreover somewhat easier to follow, centring as it does in the determination of the home authorities to obtain the grant of a permanent revenue from the island, and the equally strong resistance of

1 Ed. Cranfield to Shrewsbury, C.C. $1696-7,193$.

2 President and Council of Barbados to the Board of Trade, $i b .192$.

3 Vernon and Grey to the Board of Trade, C.C. $1697-8$, 109, I13.

4 Anonymous letter to Barbados agents, $i b .52$.

5 'The present state of Justice in the American plantations, and particularly in Barbados,' C.C. $1700,75 \mathrm{I}$. 
the Assembly to this proposal. The dispute was of long standing, and in 1683 , owing mainly to the efforts of Governor Lynch, a grant of revenue had been made for twenty-one years ${ }^{1}$. Strengthened by this minor success, the royal officials made further attacks on their objective, and in 1688 obtained a grant of perpetual revenue ${ }^{2}$. The circumstances of this grant were however not above suspicion, and even the successful party was not prepared wholeheartedly to press its advantage; for there were many doubtful features in the administration of Jamaica before the Revolution.

\section{Under Albemarle}

The rule of the Duke of Albemarle, from r689 until shortly before the deposition of James, had been notoriously corrupt and ill-advised; and his constitutional alterations had been cancelled by James. One of William's earliest acts was to renew this cancellation and restore all persons to the offices held before the Duke's arrival ${ }^{3}$. The President, Sir Francis Watson, now took over the government, but appears to have been incapable of wise rule; and in 1690 he was quietly superseded by the action of the council, who took advantage of his doubtful title to the deputy-governorship to assert that power rested in President and Council; and the records even tell of a member being suspended. 'Sir Francis Watson dissenting 4'' Jamaica, according to the attorney-general writing early in 1689 , had been subjected to great abuses of the constitution. Men had been turned out of public office and their places filled with such as 'tapsters, barbers, and the like'; elections had been interfered with, freeholders condemned for riot and fined excessively-in short it is 'as if Empson and Dudley had returned ${ }^{5}$ ' (to quote one of the many instances where landmarks in the growth of English liberties are used in support of the cause of colonial liberties).

1 Lynch's speech to Jamaica Assembly, C.C. I68I-5, I3I 7 .

2 For the broad outline of the struggle, see H. E. Egerton, 'Colonial Administration of the Crown Colonies' in Royal Historical Society's Transactions (Fourth Series, Vol. I, pp. 190 et seq.).

3 King to the President and Council of Jamaica, C.C. $I 689-92,29$.

4 Minutes of Jamaica Council and letter to the Board of Trade, $i b$. 758,873 .

5 Attorney-General of Jamaica to the Board of Trade, ib. 50. 


\section{Inchiquin}

However, in May I690 a new governor, the Earl of Inchiquin, arrived. He decided that 'the animosities here are due to fifteen or sixteen years standing of turbulent and pernicious advisers'; and one of his first measures was to suspend the Receiver of Revenue ${ }^{1}$. Inchiquin did not live long to enjoy his new government. He was soon involved in the struggle with his turbulent Council and assembly ${ }^{2}$, but in January 1692 his death vacated the governorship once more and there survive conflicting records of his conduct in that office. "No governor ever had so much money in so short a time- $f_{1} 5,000$ is well within compass-nor strove so earnestly to get $\mathrm{it}^{3}$.' The writer of this however had some personal bias, and Inchiquin's secretary brought counter-charges: 'the very men he delivered from the oppression of a former government and made councillors now strive to misrepresent his actions and asperse his memory ${ }^{4}$.' One fact may be noted in passing: under Inchiquin Jamaica was exceptionally quiet both in war measures and in affairs of trade; and yet it sprang very soon into prominence under Beeston. This fact may easily indicate a lack of personality in the former governor; for every other colonial administrator of strong character made his presence felt in the colony and his acts well known to those at home. The reign of William III was not a time when a strong governor could rule an English settlement in quietness.

\section{Beeston}

In 1693 Colonel Kendall of Barbados was appointed governor ${ }^{5}$, but this appointment never took effect. At the same time it was pointed out that an economy could be effected by keeping Sir William Beeston-who had returned to Jamaica as LieutenantGovernor after the great earthquake of 1692 -in that capacity

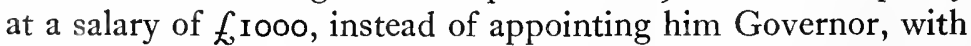
the usual salary of $f 2000^{6}$; and this somewhat discreditable

1 Lord Inchiquin to the Board of Trade, C.C. ${ }^{2} 689-92,980$.

\footnotetext{
$2 \mathrm{Ib}$. 1698 .

$3 \mathrm{Ib} .2103$.

4 Ib. 2043.

${ }^{5}$ Beeston to Nottingham, C.C. I693-6, 207.

' 'Considerations offered as to the state of Jamaica,' $i b .212$.
} 
arrangement held good until the end of 1694 when Beeston was made Governor, although his salary still figured as $£_{1000}$ in $1697^{1}$. He frequently complained of the inadequacy of this income. In 1693 he wrote that the cost of living was double his allowance, nor was even that at his disposal, owing to the lack of money to pay it ${ }^{2}$. Again in the following year, the Treasury was so poor that he could not take his allowance ${ }^{3}$.

The assembly too was not on better terms with Beeston than were those of the other islands with their governors. In I694 it refused to raise money except on the bargain that the governor should reimpose martial law instead of civil, the purpose being, he declared, to shield six or eight of the members from the necessity of paying their debts. The entertainment of soldiers was also disputed. As Beeston added, the Assembly knew its power ${ }^{4}$. It was with reluctance that the House could be persuaded to vote $f_{\mathrm{I}} \mathrm{I}, 000$ for the payment of its creditors; and the greater part refused to have anything to do with an increase of revenue and with the collection of quit rents. And yet by some means Beeston succeeded in obtaining a bill voting the revenue indefinitely ${ }^{5}$. However, the hopes raised by this were shattered the following year. The new assembly declared that the previous bill was passed by an unduly elected House; and Beeston could not persuade them to make a new bill for perpetual revenue. 'If they must have fetters, they would rather have them put on by others than themselves ${ }^{6}$ '' Another sore point with the Assembly was the disallowance of their laws at home:

the people think it hard that after the trouble and expense of calling an assembly, a law should be rejected on the bare opinion of one or two in England, who have nothing to do with it; and say that people in England cannot so well know the reason for making a law as those who make it?

Trial of public officers by the English council was also resented-especially in connection with a new law of 1698 forbidding any Governor, Lieutenant-Governor or Judge to be a factor in the sale of negroes-the objections being based on the

1 Beeston to Blathwayt, C.C. $1696-7$, ro8o.

2 Beeston to the Board of Trade, C.C. $1693^{-6}, 477 .{ }^{3}$ Ib. 1194 .

4 $I b .1517$.

5 Ib. 1970.

C.C. $1696-7,40$.

7 Ib. 130. 
idea that it was contrary to Magna Carta that a man should be tried elsewhere than by his neighbours where the fault was committed $^{1}$. Friendly relations between colony and mother country were not improved when a Jamaica act, compelling holders of offices under patent to reside in the island, was repealed in 1700 on the ground that it was derogatory to the royal prerogative ${ }^{2}$; and Beeston ended his period of government unsatisfactorily.

After years of depression, he was at last able in 1700 to report that 'all things go well and quietly' ${ }^{3}$ '; but his satisfaction was premature. The Board of Trade was determined to obtain an act for perpetual revenue, since the period of twenty-one years for which the governor was empowered, under the vote obtained by Lynch, to raise revenue, would come to an end in 1704 . In I 70 I they threatened, unless the assembly would comply with their wishes, to revive the act of $\mathrm{r} 688$ for permanent revenuethe act of doubtful legality, which had been shelved ${ }^{4}$; but the representatives were not to be intimidated and protested ${ }^{5}$. A quarrel now began between assembly and governor. The House issued a proclamation without the governor's consent; and its marshal was therefore arrested by Beeston for executing the order ${ }^{6}$. The assembly then passed a Bill putting the expenses of quartering troops on the Treasury of Jamaica. Beeston thereupon placed the island under martial law: 'it's the people grown rich and proud, and now would set up for themselves,' he lamented ?. Meanwhile, Brigadier-General Selwyn had been appointed to relieve the sturdy governor ${ }^{8}$, and Beeston had the mortification of leaving the island in confusion, when he hoped that at last its prosperity was assured.

In the remaining West Indian governments, the Bermudas and the Bahamas, political affairs during this period were in an almost chaotic condition. Both groups of islands were too small

1 C.C. I697-8, 1028.

2 Board of T'rade to the King, C.C. I70o, 372.

3 Beeston to the Board of Trade, $i b .927$.

4 Board of Trade to the King, C.C. I7OI, 67.

5 Beeston to the Board of Trade, $i b .622$.

6 Minutes of Jamaica Council in Assembly, ib. 630.

7 Beeston to the Board of Trade, $i b .676$.

8 Vernon to the Board of Trade, $i b .638$. 
to be considered colonies in the full sense of the term, and, being also far removed from the main centres of civilization even in the New World, while yet situated on or near the main trade routes, they tended to lapse into barbarity and to form an asylum and rendezvous for pirates and other undesirable characters. Thus their constitutional disputes appear, after a lapse of 200 years, much in the nature of comic relief, after the spectacle of a steady fight for power in the greater colonies, and yet the main actors must have felt more of tragedy in their situation.

\section{Bermuda}

In I69o Bermuda complained that the governor would not take the advice of his council, or impart public letters to its consideration, and that he refused to admit a Collector of Customs. The petitioners illustrated his corrupt practices by instancing his appropriation of a stranded sperm whale, which Governor Robinson had in some way contrived to convert to his own use. This petition was stated to be the second of its kind since the first had been intercepted, with the privity of the Governor ${ }^{1}$. The council took revenge on the arbitrary Robinson by refusing him a house or rent ${ }^{2}$. When a new governor, Isaac Richier, arrived in I69I, he found acts passed without any record remaining, Robinson having kept acts in his custody, and suffered no public matters to be recorded. All the acts of the previous assembly had therefore to be annulled ${ }^{3}$. Moreover the assembly itself was too large, numbering thirtysix; and important people had great powers of influence for themselves ${ }^{4}$.

The following year, charges of disaffection were brought against Richier himself, and the Board of Trade decided to investigate ${ }^{5}$. A new governor, one Goddard, was appointed to supersede him, and on his arrival found great coniusion, owing, he claimed, to Richier. There had been an attempt at open rebellion in which one of Richier's friends was killed; and when

1 Council of Bermuda to the Board of Trade, C.C. I689-92, 945.

2 Governor Robinson to the Board of Trade, $i b .794$.

3 Governor Richier to the Board of Trade, $i b$. 1484 .

${ }^{5}$ Nicholas Trott to the King, Report of the Board of Trade, $i b .2636,2700-1$. 
the murderer was placed in irons, a protest followed that such an act was against Magna Carta ${ }^{1}$. The new governor soon wearied of his government, and in 1694 was petitioning for his transference to Maryland, the perquisites in Bermuda being so small that they hardly paid his expenses ${ }^{2}$. Meanwhile he threw himself heartily into the prosecution of Richier, bringing charges against the latter of cutting down the King's timber for his own use, trading directly with Scotland, and neglecting defence against pirates ${ }^{3}$; and he also demanded that Richier should hand over half the profits made since the date of Goddard's commission. On Richier's refusal to grant this somewhat arbitrary request, Goddard imprisoned him ${ }^{4}$. The prisoner succeeded in sending home a message to the authorities, who ordered his release on giving due security, Goddard to obtain full evidence on both sides for his trial ${ }^{5}$. Richier however was still in prison a year later (March $\left.{ }^{6} 695\right)^{6}$; and his case did not come before the Board of Trade until 1697. He described Goddard's action in making himself and the council into a peculiar court to try and to sentence Richier; and the Board of Trade decided that the only step which could be taken under the circumstances was to recall both governors ${ }^{7}$. The new governor, Day, on his arrival made a clean sweep of all concerned in the Goddard-Richier case, which had brought the island to great disorder ${ }^{8}$, but Day himself was very soon in the same disfavour as his predecessors, and was recalled in 1700 to answer charges of corruption ${ }^{9}$. His chief offence had been the imprisonment of Edward Randolph, the Surveyor of Customs, for his conduct in enforcing the regulations of the Navigation system ${ }^{10}$. Randolph's report on Bermuda is therefore bitter; but his conclusion is worthy of record: 'the best and

1 Richier to the Board of Trade, C.C. $1693-6,420$.

2 Goddard to Trenchard, $i b .680$.

3 Goddard to the Board of Trade, ib. 798.

* Richier's petition to the King, $i b$. 9 I $\mathrm{x}$.

5 Board of Trade to Goddard, $i b .955$.

- Richier to the King, and Richier to Goddard, $i b .1724, x 887$.

7 C.C. $1696-7,733,1136$.

8 Lieutenant-Governor Day's instructions, and letter to the Board of Trade, C.C. $1697-8, \mathrm{r} 83,899$.

9 Vernon to Day, C.C. I700, 733.

10 See below, p. 168. 
only means for preventing the succeeding 'governors from oppressing the inhabitants by arbitrary practices is for the governor to be allowed not less than $£ 500$ a year ${ }^{1}$.' It was at least the duty of the English government to take steps that would break the succession of governors established by Robinson, Richier, Goddard and Day.

In I70I Bermuda, hearing that it was proposed to reunite the Bahama Islands to the crown, asked that it might be joined to that government for mutual interest. Then followed the remark that Bermuda could well spare five hundred men, women, children and negroes for the Bahamas ${ }^{2}$, an offer which shews that Bermuda did not suffer from the depopulation which was the common complaint of the larger islands. It may be accountable on the grounds either that there was not a livelihood for the population, which seems an unlikely state of things, or that the planters wi hed to preserve the private and exclusive nature of their government against an increasing population.

\section{The Bahamas}

The Bahama Islands were-alone in the West Indian islands -in proprietary hands, under the same proprietors as Carolina ${ }^{\mathbf{3}}$; but this peculiarity does not seem to have ensured a better government than in the crown colonies. The first governor, Cadwallader Jones, was directed by the proprietors to rule with council and assembly ${ }^{4}$ but he does not appear to any large extent in the records and indirect evidence points to his being of not too high character ${ }^{5}$. His successor Trott also appears to have participated in corruption ${ }^{6}$. In the case of either, however, it must be conceded that, in the words of Mr Fortescue, 'had he been an honest man, he would have found himself very solitary in the Bahamas of that day?' In December 1696 a new

1 Randolph to the Board of Trade, C.C. I70o, 936.

2 Journal of Bermuda Assembly, C.C. I7OI, rorg.

3 In the early years of William's reign the proprietors of Carolina were: the Earl of Craven, Lord Ashley, Sir P. Colleton, William Amy, and Lord Carteret; of whom the first three were proprietors of the Bahamas. (C.C. $1689-92$, index.)

4 Instructions to Cadwallader Jones, ib. 555.

5 Board of Trade to the Lords Justices, C.C. I696-7, I400, 68 I.

- Petition of Thomas Bulkeley to the King, ib. 68r.

7 C.C. I693-6, Introd. p. xxix. 
governor, Webb, superseded Trott; and the Board of Trade attempted to prevent a repetition of bad government by insisting on his approval by the King before the appointment could take effect ${ }^{1}$. Some suspicions of Webb disturbed the Board $^{2}$, but the proprietors supported him and agreed to augment his salary; and the board agreed to the appointment ${ }^{3}$. Again in I700 the proprietor's nominee received approbation, but this time the Board of Trade asked security from the proprietors for his good conduct 4 . The attorney-general however could not support this claim of security given for a deputy; but pointed out that if the laws were not obeyed the charter might be forfeited, and with this the board were obliged to rest content ${ }^{5}$. Whether the new governor, Haskett by name, maintained a higher standard after this is not clear; but a year later he was writing home in panic, asking for a guard of at least thirty soldiers, and fearing that he would be roasted alive, as the Spaniards had treated a governor in that neighbourhood, for interfering with illegal trade ${ }^{6}$. Haskett escaped this uncomfortable fate, but a revolution did break out in the Bahamas, and he was shipped to New York. 'My justly and honestly putting the King's laws in execution were the cause that I very nearly escaped being executed myself?,' was the comment with which Governor Haskett disappeared from the scene. Thus the close of William's reign saw the Bahama Islands without any governor at all.

\section{(f) The Political Situation}

The defects of small communities

It is evident from such a study of the political aspects of colonial affairs that the colonies unfortunately suffered from the defects peculiarly associated with small communities. There was the narrowness of outlook which saw only the interests of the small group, and divided the settlements beyond hope of active defence; there was the slanderous disposition which made almost every high official the butt of false accusations, which

1 Ed. Randolph to the Board of Trade, C.C. $1696-7,542$.

$2 \mathrm{Ib} .668 . \quad{ }^{3}$ Board of Trade to the King, $i b .709$.

${ }^{4}$ Popple to Thornburgh, C.C. I700, $356 . \quad{ }^{5} I b .566,597$.

${ }^{6}$ C.C. I7OI, 655 .

7 Ib. 1113. 
hindered good administration and failed adequately to discredit bad; and above all there was the association of public position with private gain, seen at its worst in Bermuda and the Bahamas, but quite evident also in the careers of Benjamin Fletcher and the elder Codrington. The governor had many opportunities for thus adding to his fortune, and the general circumstances of his treatment by the English government were not such as would discourage the use of these. There was great temptation for a governor left without pay, as in the cases of Beeston in Jamaica and Ingoldsby in New York, to obtain a salary at the cost of honest administration, either by corrupt appointments, as in the charges against Fletcher; by selling popular privileges, the ease of which is seen in the case of the Pennsylvanian Bill for a new constitution ${ }^{1}$; or by the judicious use of the Navigation system. This latter practice was perhaps the most widespread of all, since evasions of the trade laws do not appear to have counted as serious offences against the standards of honourable conduct. Not only were the offenders found in the disorganization of such settlements as South Carolina, where Governor Blake 'drove a fine trade of seizing and condemning vessels '; by this $\sin$ fell also Fletcher and Codrington. And it is not without significance that the younger Codrington, whose career is stained by no such accusations, explains that he would not have accepted the governorship of the Leeward Islands, if he had not possessed an estate there which needed supervision. For that reason alone it was to his interest to accept the position ${ }^{3}$ :

\section{Constitutional conflicts}

During William's reign, there emerged into light two main lines of conflict within the constitutional system of colonial government-conflict between governor and assembly, and between crown and proprietary (or charter) governments. In the West Indies the first of these conflicts is seen without the complications caused by the second; but on the mainland, its effects are equally pronounced and more important. In the case of the mainland colonies, the first struggle, in order of develop-

1 See above, p. 108.

3 See above, p. 136 .

2 Randolph to Vernon, C.C. I700, 476. 
ment, was that between the crown and the proprietor or the charter-government. In Maryland, William superseded the Roman Catholic proprietor, whose authority was shaken by the revolution; in Pennsylvania, a similar policy was attempted, but the result was not successful, and ended in compromise. In New Jersey, crown rights were asserted even more zealously than legal proceedings subsequently justified, but the proprietors, in spite of their victory, found their position untenable and surrendered their rights at the end of the reign. Even in the Bahamas, where, as in Carolina, private interests were allowed to run amok, there were suggestions that royal interference was imminent ${ }^{1}$. In the proprietary colonies, the revolution was welcomed as the occasion of gaining riddance from private control-except in the one case of Pennsylvania, and there royal aggression did not succeed-and thus no great effort on the part of English authority was needed to oust the unpopular proprietors. In Massachusetts, the stronghold of charter rights, the reverse was the case. The struggle in Boston was directed against the English government as such, for the colony was its own proprietor; and thus the revolution increased rather than appeased the zeal of that colony for independence. Nevertheless, the new King confined the indomitable spirit, although but temporarily and within wide bounds.

In the colonies which had passed to the stage of crown government, the conflict was between governor and assembly. This was the case in the three West Indian governments; and, on the mainland, in New York and Virginia, then in Maryland and New England, where time after time the popular House refused grants of revenue, or made them only conditionally, to the governor, even in time of urgent need. The accession of William III stood for representative government, and may therefore fairly be taken as the beginning of that movement by which the assembly of a colony, gradually appropriating to itself the power over taxation and revenue, reduced the power of the governor-and therefore in practice that of the crownand brought about the deadlock which in fact issued in separation. In both these conflicts, the difficulties were made more

1 See above, p. 145 . 
acute by the French war, and the measures necessary for defence. The necessity of preserving the bounds of empire-of tradeempire that is-made the crown unwilling to press resistance in the colonies to the point of danger; while it also led to schemes of union, such as that of New England under Bellomont, which accentuated the natural tendencies of the colonies to disunion and increased mutual jealousies.

\section{The meaning of the colonial desire for independence.}

What the colonies really wanted was an isolated independence, free from those state ties which had irked them in England. They still maintained a keen sense of those objects which had induced their pioneers to leave England. Apart from the immediate causes of their migration there were certain features in English government against which they, equally with other Englishmen, had rebelled. These are symbolized in the allusions to Empson and Dudley, and to the contraventions of Magna Carta. But whereas Englishmen at home had almost forgotten them, as belonging to the remote past, the settlers in the New World still feared their revival, not in the shape of royal tyranny against the people of England; but as English tyranny against the people of America. Moreover this was not an essentially unreasonable view. The whole navigation system assumed, and even apart from this, there was a tendency for colonial administration to assume, that colonial interests were different from those of England, and that English claims must always come first-not necessarily that England must have the whole field; she could make concessions involving self sacrifice; but England must always be first in that field. Therefore the rise of popular government against the English administrator must be carefully watched and restrained. It is not an exaggeration to say that in this reign the rival ideas can be seen rapidly approaching an impasse. For the following sixty years the catastrophe was postponed by danger from outside carelessness and neglect, but without a change of attitude on one side or the other it was bound to come in the end. And at last English statesmen discovered how far they had drifted under the Hanoverian régime. 


\section{CHAPTER V}

\section{THE ECONOMIC ASPECTS OF COLONIAL POLICY}

The disadvantages of the navigation system were brought home by war, which accentuated the difficulties of working; whilst there was no tendency to mitigation or re-organization. Meanwhile the colonies were developing.

\section{(a) The Navigation System}

\section{The ideas behind the system}

Perhaps the greatest factor in bringing about that fatal difference of thought between England and the American settlements was the trade system, the ideas of which are best expressed in the writings of William's reign. The old view of excessive tyranny, by which the mother country took all from the colonies and gave nothing in return, has undergone much modification under the light of historical research; but however the navigation system may be justified, the fact still remains that those Englishmen who guided and expressed the policy of their country towards the colonies, were bound completely by what may be called the 'Plantation' view of colonization. The colonies, in their view, were productive settlements which must bring additional gain in some form to the land which made them. Considering the previous history of colonization under Spain and Portugal, and the history of British settlements themselves during the first half-century of their foundation, even astute statesmen can hardly be blamed for such ideas. They could see the West Indian sugar-producing settlements, rich in one of the essentials of a trade-empire; the tobacco production of the southern colonies of North America, with a ready market in England, and, through England, in Europe; the fisheries of Newfoundland, also rich in produce and moreover a regular training ground for seamen, the backbone of Imperial defence, recognized again at the end of the Stuart rule, as at the beginning. These possibilities were responsible for the interest in colonies, aroused under the Commonwealth and continuing after the Restoration. A productive use was now seen 
in the settlements which were rightly or wrongly considered to have been settlements by the refuse of population ${ }^{1}$. Some, such as New England, could not yet fall into this scheme; but possibilities were appearing with the increased production of naval stores to supplant the Baltic products; and meanwhile that portion of the American mainland had to be considered an unproductive settlement, disadvantageous to the home country. This view of the colonies, as serving primarily to enrich England, carried with it the navigation system, justified typically by Sir Josiah Child in well-known sentences ${ }^{2}$ :

All Colonies or Plantations do endamage their Mother Kingdoms, whereof the Trades of such Plantations are not so confined, by severe laws and good execution of those laws, to the Mother Kingdom.... The Dutch will reap the greatest advantage by all Colonies issuing from any Kingdom of Europe, whereof the Trades are not so strictly confined to the proper Mother-Kingdom.

... New England is the most prejudicial Plantation to the Kingdom of England.

...It is more for the advantage of England that Newfoundland should remain unplanted.

An earlier extract shews even better the type of consideration which would be given to an objection made by the colonies to the English imperial policy, as expressed in the Laws of ' $\mathrm{Trade}^{3}$ :

The inhabitants and planters of our plantations in America say, this Act will in time ruin their plantations, if they may not be permitted at least to carry their sugars to the best markets, and not be compelled to send all to, and receive all commodities from England. I answer, If they were not kept to the Rules of the Act of Navigation, the consequence would be that in a few years the benefit of them would be wholly lost to the nation; it being agreeable to the policy of the Dutch, Danes, French, Spaniards and Portuguese and all nations in the world to keep their external Provinces and colonies in a subjection unto and dependency upon the Mother Kingdom; and if they should not do so, the Dutch, who as I have said are masters of the Field in Trade, would carry away the greatest of advantages by the plantations of all the Princes in Christendom, leaving us and others only the trouble of breeding men and sending them abroad to cultivate the ground and have bread for their industry.

1 Child, A New Discourse on Trade.

2 Ib. Chap. x, p. 178 .

$3 \mathrm{Ib}$. Chap. IV, p. II 5. 
No doubt in all this there was a semi-conscious balancing of the privilege granted to the emigrants of still bearing their English name and a vague right to protection in their newlyfound liberty from more definite and irksome governmentthis privilege, with the duty of serving the commercial interests of the country they had left. But in any case the interest of England was the main criterion of colonial policy. This point of view is, I repeat, not an altogether unreasonable one at the time; but, unfortunately for all parties concerned, new factors were arising to upset the smooth working of such a system.

In the first place, as we have seen, the advance of France on the northern frontier made it necessary for England to take up a definitely imperial position-or to refuse to do this; at any rate some decision had to be made, one way or the other. She decided imperially and was therefore compelled to face problems of organization. Secondly, the colonies were by now gaining real political feeling and some approach to national aspirations within their own small states. Both these factors meant that no longer could the colonies be considered purely as trading settlements, with commercial interests alone. No one will of course attempt to declare that in the reign of William III these factors suddenly appeared. Nevertheless the period affords a better opportunity of observing the development than any other, owing no doubt to the accident of the revolution and the French war, which hastened an otherwise gradual movement. The navigation system was designed to control trade settlements alone. The harm it did was the result of an attempt to control communities which were rapidly developing political characteristics, and with them definite political interests, which did not coincide with those of England.

\section{The stiffening of the system}

The navigation system then continued to dominate the practice of colonial policy during William III's reign. In I 689 the Spanish commissioner-general for the introduction of negroes into the Spanish Indies, asked for power to buy negroes from British ships for exportation, and to import Spanish 
produce into the West Indies, for the relaxation of penalties in cases of unlawful trade by subordinate sailors, and for arbitration by the governor of a colony in cases of disputes with foreigners; but the English Government refused to relax the spirit of the navigation system, replying that the Trade Laws must be observed. Apart from this, Spanish interests would be considered $^{1}$. Moreover, not content with this determined attitude, the home authorities attempted by a statute of $1696^{2}$ to stiffen the framework and to fill up the sources of leakage in the system. This act, 'for preventing Frauds and regulating Abuses in the Plantation Trade,' began by stating that great abuses were daily committed to the prejudice of the English navigation, and the loss of a great part of the plantation trade to this Kingdom. It first laid down that no goods should be exported from or imported to the plantations except in ships built there or in England or Ireland, with three-quarters of the crew Englishmen. The governor of each plantation was for the future bound by oath to enforce this statute and the other requirements of the navigation system; naval officers were to give security to the English Commissioner of Customs for the due performance of their duty, and officers of the revenue in the colonies were given the same powers of search and seizure as customs officers in England with similar powers of requiring assistance. Provision was further made for the reward of informers, on whom the prosecution of offenders mainly depended. It was also enacted that the payment of duties on goods passing from one colony to another did not exempt them from the necessity of giving security against those goods being shipped to foreign countries. With these and other minor regulations this statute attempted to enforce more efficiently the navigation laws of the Restoration. It decreed moreover that the penalties attached to offences against these laws should be enforced

in any of His Majesty's courts at Westminster or in Ireland, or in the court of admiralty held in His Majesty's plantations respectively, where such offence shall be committed, at the pleasure of the officer or informer;

1 C.C. $1689-92,369-7 x$.

2 Statutes at Large (7 and 8 William III, c. 22). 
thus providing against the opposition of colonial courts or juries by the system of admiralty courts, extended during the latter half of the reign.

\section{Admiralty courts}

The attempt to strengthen the administration by the wide extension of courts of admiralty began with the New Council of Trade in 1696 , who recommended the establishment of such courts in each colony, for the prosecution of bonds, the trial of seizures, and for other matters of similar nature ${ }^{\mathbf{1}}$. Record of previous commissioners of admiralty granted to governors survives only to the cases of Andros (from the Duke of York) in 1678 , Dongan from the King in 1682 , and Fletcher in 1692 , the latter commission including the Jerseys, Pennsylvania and other outlying areas ${ }^{2}$. Randolph therefore submitted the names of suitable persons to be officers of these courts, and his nominations were embodied in the official recommendation ${ }^{3}$. The Admiralty now reported that all governors might have commissions of admiralty if they would apply, but that several had not requested such authority. Commissions had, however, been granted to the governors of nine colonies, including all the most important ${ }^{4}$. The Board of Trade now ascertained from the law officers that the King could appoint commissioners of admiralty in the proprietary colonies ${ }^{5}$; and by means of thus utilizing a system which was already partially in practice, the English Government was enabled to spread its responsible officers among all the colonies and groups of settlements. In these admiralty courts, which were without juries, there was a considerably greater likelihood of the English interest being served and authority upheld; but admiralty jurisdiction was particularly repugnant to the people of America, and brought in fresh difficulties, as will later be seen.

1 Commissioners of Customs to the Treasury, C.C. I696-7, 107 (i).

2 Andrews, 'Materials for American History in the Public Record Office,' Departmental papers (Admiralty), p. 35 .

${ }^{3}$ C.C. $1696-7,120,131,165$.

4 Massachusetts, New York, Virginia, Maryland, New Hampshire, Jamaica, Barbados, Leeward Islands and Bermuda.

${ }^{5}$ C.C. $1696-7,409,466$. 


\section{(b) The Defects of the System and of ITS ADMinistration}

\section{Loss of trade}

For the colonies, the revolution of 1689 and the consequent war with France meant disastrous loss of trade. In September I689 it was reported that sixty-two English ships, chiefly from America and the West Indies, had been recently taken by French privateers $^{1}$; and Macpherson relates ${ }^{2}$ how in the account laid before Parliament in 1692 it appeared that the French had, in the past two years of war, taken from England no fewer than 3000 sail of trading vessels great and small; whilst within the same period we had taken from France only 67 merchant-ships. It was further explained that France owed her comparative immunity to the extent to which her trade was conducted in foreign ships; but this did not diminish the actual loss inflicted on British shipping. Moreover, there was at the same time great difficulty in raising the required complement of sailors either for a merchant-ship or for a man-of-war; since for the navy, recruiting was hindered by the low pay, whilst for the merchant service, which was constrained to offer double the royal rate, men were dissuaded by the irksome liability to be pressed for the King's ships. Thus Sir Francis Brewster in I695 was complaining that seamen could not be obtained to man our ships and that foreign shipping had to be employed ${ }^{3}$. $\mathrm{He}$ also suggested that the only remedy was for volunteers for the merchant ships to be promised freedom from empressment; so that, with this increase in numbers, the rate of pay would not need to be so high; and this fall in rate of pay would encourage recruiting for the King's ships, which maintained a low rate ${ }^{4}$. However, be this as it may, the fact remains that there was a shortage of seamen during the war. A third discouragement to merchant shipping lay in the system of convoys, which were required to guard against French privateers. In certain cases, the commissioners of customs would refuse to

\footnotetext{
1 Account of ships taken lately by French privateers, C.C. I689-92, 467 .

2 Macpherson, Annals of Commerce, Vol, il, p. 650.

3 Brewster, Essays on Trade and Navigation, p. 5. 4 Ib. p. 75 .
} 
clear ships, which were ready to sail, until their convoying fleet was made up, often a long process $^{1}$; so that this necessary measure of defence often involved considerable delay and inconvenience. Such difficulties naturally inflicted hardship on the colonies, and shewed the disadvantages in time of war of the navigation system. In 1696 the West Indies, especially Jamaica, were complaining that 'there came not from England necessaries enough to furnish the people's wants, nor ships enough to take away their produce.... Their wants oblige them to countenance all importers ${ }^{2}$ '' Again the following year, the burden of complaints from the same quarter was that no ships came from England to take away their produce, and no one else was allowed ${ }^{3}$. In so far as the navigation system was responsible for the ill condition of any colony, the remedy of evasion lay obvious and ready to hand; and, in fact, complaints of illegal trade and piracy became very widespread during the war. The two offences, although distinct, may be classed together in this period, as a great proportion of the charges against the colonies include the two as one. Illegal trade and the harbouring and encouragement of pirates were merely two forms of evading the troublesome trade restrictions.

\section{Illegal trade and piracy, Massachusetts}

In Massachusetts, complaints occurred with the revolution, when the arrest of Captain George prevented him from preserving the coasts from pirates and enforcing the acts of navigation ${ }^{4}$; and the following year Randolph preferred charges against the Boston people, alleging daily violations of the laws of trade ${ }^{5}$, which charges were borne out by letters to merchants in England, and by the reports of visitors, and were accepted by the Board of Trade for inclusion in their representation to the King. Dealing especially with Boston, Randolph stated that the aims of that town were to restore free trade for their vessels to all parts of Europe, to prevent any collector accepting duty

1 Board of Trade to the King, C.C. I696-7, 615.

2 Beeston to the Board of Trade, $i b$. r 30 .

${ }^{3}$ Letters of Dec. 1697, C.C. I697-8.

4 King to the Governor of Massachusetts Bay, C.C. I689-92, 340.

5 Board of Trade to the King, ib. 773. 
(for instance, by imprisonment and threatened execution of Randolph himself), and to make Boston a depot for European commodities. He challenged the town to shew copies of bonds taken from captains of merchantmen loading the enumerated commodities $^{1}$. The Bostoners in self-defence asserted that Randolph sought to be the only informer, and to discredit their charter, which he was compassing with destruction by false reports. They appended disproofs of his charges in several cases, but left the main accusations unrefuted ${ }^{2}$. Usher also declared that Massachusetts was frequently sending the enumerated commodities to France, Holland and Spain, and importing goods thence without clearing in England; whilst the collectors were 'laid aside' and obstructed ${ }^{3}$. Phips himself was accused by Collector Brenton of hindering him with violence in the execution of his duty, Phips himself carrying on illegal trade, and having prevailed on the assembly to exempt ships trading from colony to colony from entering or clearing ${ }^{4}$.

\section{Rhode Island}

In Rhode Island the local government excused itself by explaining their need of better fortifications before they could compel ships trading there to yield obedience to law ${ }^{5}$; and the colony certainly appeared to need this explanation. According to Randolph it was 'a free port to illegal trading and pirates for all places' ${ }^{6}$; and a Boston merchant expressed himself still more strongly: "they are such a bloody crew of privateers at Rhode Island that the government cannot rule them, and sober men are in fear of their lives'; there is daily plundering of vessels as they come in; and 'unless the King take present care, privateers will rule the Island ?' 'The Board of Trade considered towards the end of the war that in the trial of pirates there was too frequent mention of New England as the place from which

1 Randolph to the Board of Trade, C.C. $1689-92,949$.

2 Answer of New York agents to Randolph, ib. 967.

3 Usher to the Board of 'Trade and to Nottingham, C.C. $1693-6,39,40$.

4 Commissioners of Customs to the Treasury, ib. 689 .

5 Governor of Rhode Island to the Board of Trade, $i b$. 1296.

- Randolph to the Commissioners of Customs, C.C. $1696-7,396$.

- Benjamin Davis to Edward Hill, ib. 554 . 
the pirates were fitted out, and where they were entertained ${ }^{\mathbf{1}}$. As an example of this, a long account was given of the pirate Tew-also largely responsible for the fall of Fletcher-fitting out at Rhode Island for piracy in the Red Sea ${ }^{2}$.

\section{Maryland}

Nor do the other colonies seem exempt from a share of blame. Maryland is 'a loose government, and suffers illegal traders, so their tobacco sells well and they have plenty of goods ${ }^{3}$.' A man reported to have brought $£ 3000$ of goods direct from Holland was regarded with something akin to respect for his conduct; although his case might indicate that such persons were rarer in Maryland than in New England. Masters of ships did indeed complain of his being permitted to trade; and the deponent explained this by asserting that the collectors were probably bribed. 'Clandestine trade is easy, as the collectors live far up in the country ${ }^{4}$ ' Randolph also included Maryland in his general denunciation, after making a tour of inspection there ${ }^{5}$; and although Governor Copley complained of the surveyor's conduct, he confined his complaint to Randolph's methods, rather than his aims. 'He has made the country weary of him;... boasts that he has lived 25 years on the curses of the people, and I am sure he never wants them ${ }^{6}$.' Randolph was often unfortunate in the issue of his prosecutions. In July I 696 he sent a list of the vessels seized and prosecuted by him in Virginia, Maryland and Pennsylvania, shewing that he lost his suit in every case ${ }^{7}$. He further sent reasons for the continuance of illegalities, attributing these to the ignorance, remissness or connivance of collectors; persons of little estate given as security; the partiality of juries and courts, some not qualified to act; the large stocks of goods kept on shore and easily increased surreptitiously before an incoming ship was cleared; and the use of forged certificates, through the fault of

1 Board of Trade to Lieutenant-Governor Stoughton, C.C. I693-6, 604.

2 John Graves to the Board of Trade, C.C. I696-7, 744 .

3 Nicholson to the Board of Trade, C.C. $1689-92,2075$.

4 Information of John Twitt, ib. I95I.

5 Randolph to Commissioners of Customs, ib. 2295.

${ }^{6}$ Copley to the Board of Trade, $i b .2370$.

7 List of vessels seized and prosecuted by Randolph, C.C. $r 696-7$, I 20. 
the naval office. Randolph added details, blaming especially the proprietary governments ${ }^{1}$. In some ports, he declared, false seals and certificates were kept, and stores were collected in quiet places for the use of illegal traders ${ }^{2}$. Lawrence, the secretary of Maryland, stated that county juries would hardly ever find against an illegal trader ${ }^{3}$; and Governor Nicholson also found difficulty in getting either juries or judges to convict. He therefore proposed special courts of exchequer in Maryland and the neighbouring colonies; but the Board of Trade pointed out that the courts of vice-admiralty would serve this purpose, and although Nicholson disagreed, he could not obtain his exchequer courts ${ }^{4}$. Nicholson added a significant qualification to his statement of judicial appointments: ' $I$ have put into them [i.e. the courts of judicature] able, rich, and honest men (except in the way of illegal trade).' Maryland, he declared, would not petition for a royal frigate, because it would tend to check their misdemeanours ${ }^{\overline{5}}$.

\section{Virginia}

In Virginia there was little serious outcry except by Randolph. Andros implied that the laws were not kept by referring 'to his desire for fixed ports which would be a more effectual prevention 6.' In I699, under Nicholson's government, an act was passed against piracy, giving any civil or military officer power to arrest, and kill if resisted.

\section{Pennsylvania}

In Pennsylvania, the complaints were directed chiefly to breaches of the law committed by Scotchmen. Complaints against illegal trade generally did appear, and Nicholson found several places 'fit to manage illegal trade, and the people generally inclined to make use of them whenever they can.' Pirates also were there, having brought great spoils from the Red Sea ${ }^{7}$. Pennsylvania was however especially guilty with

1 Randolph to Commissioners of Customs, C.C. $1696-7,149$.

2 C.C. $1689-92,2295$.

3 Memorial of Sir Thomas Lawrence, C.C. I693-6, I916.

4 Board of Trade to Nicholson, C.C. $I 696-7,658$.

5 Nicholson to the Board of Trade, $i b$. 1178 .

6 C.C. $1693^{-6}$, 1916.

7 Ib. $2303-4$. 
Scotland ${ }^{1}$. The Lords of the Treasury included both Virginia and Pennsylvania with Maryland in their report on illegal trade of July 1694, deciding that the merchants trading fairly had great cause for complaints and making the usual ineffective suggestions that suitable vessels should be sent with experienced commanders, to cruise on the coasts, the officers to inspect collectors' books, under the supervision of the governor ${ }^{2}$.

\section{Fletcher's case}

In I 699, shortly after the arrival of Bellomont in New England the report on Fletcher's conduct was compiled. He was found guilty of actions contrary to his duty and tending to encourage piracy; and had offered no extenuation of his intimacy with the notorious pirate, Tew, except the pleasantness of the latter's conversation, and Fletcher's desire to reclaim him from an ill habit of swearing ${ }^{3}$. The Board of Trade agreed that many of Fletcher's offences were committed with the consent of his council $^{4}$.

\section{New York}

Bellomont on his arrival in New York found the customs decreased by one half from the receipts of ten years previous, in spite of the fact that the volume of trade had been doubled, and the city grown vastly rich and prosperous ${ }^{5}$. The merchants were so much used to unlawful trade that they were almost ready to mutiny on some seizures that Bellomont caused to be made on unfree bottoms. 'The collector, one of Fletcher's adherents, was lax in his duty, and by his delay, the ships were enabled to unload $£ 20,000$ worth of cargo. Bellomont proceeded to describe the 'unaccustomed disturbance' caused by

I C.C. $1693^{-6}, \mathrm{I} 897$.

$2 I b .1139$.

3 It may be of some value for correct ideas of the standards of the time to note that the original plea in this often misquoted passage was that of reclaiming Tew from 'an ill habit of swearing' (not ' $a$ vile').

${ }^{4}$ C.C. $1699,167$.

5 Chidley Brooke, the collector referred to, accounted for this decline by the injury done to retail trade by the imposing of a lower limit on wholesale, by the removal of a duty on spirits up the Hudson River, and the substitution of one on Indian goods, hindered by the war. The additional customs duty and the convenience of private wharves outside merchants' houses had also encouraged them to run their goods (C.C. I699, $5 \mathrm{I}$ ). 
the laws being enforced ${ }^{1}$, and the great numbers of pirates who were fitted out at New York or Rhode Island, and manned at New York, openly declaring their destination to be the Red Sea and the East Indies. Fletcher must have connived at this conduct $^{2}$, for such to be the condition. While Bellomont was thus zealous for the law, Randolph was no whit behind. He confirmed the statement that pirates had been abetted in Rhode Island $^{3}$; and Bellomont in 1699 was writing home that piracy and illegal trade were the 'belov'd twins' of New York', and would prevail until good judges and law officers were sent out, a man-of-war with an honest captain provided, and pay and recruits sent for the four companies of regular soldiers ${ }^{5}$. Randolph meanwhile had been suffering several set-backs in his determined prosecution of illegalities. Within a few months he was arrested in New York for making certain seizures in Virginia and was then imprisoned in Pennsylvania for telling the governor that he ought to have the royal approbation ${ }^{6}$.

\section{Pennsylvania}

Pennsylvania was still a thorn in the flesh of its neighbours. Colonel Quary, the judge of Admiralty, complained that its government was enjoining trial by jury in all cases, thus annulling his commission against pirates ${ }^{7}$. In 1699 he was obliged to hold his court forty miles from Philadelphia, because of abuse levelled at him and his authority: 'I might as well have stayed at home, since no obedience is paid to the orders and decrees of the court ${ }^{8}$.' The marshal of the Court of Common Pleas, on producing Quary's commission, was thus greeted by the attorney-general of Pennsylvania: 'What hast thou got there, John? A fine Bay? Dost think we are afraid of a Baby?' (pointing to the King's effigies) 'and a Pinn Box' (the Great Seal) ${ }^{9}$. While allowing for the effect of this peculiarly irritating method of opposition, it can hardly be claimed that the royal

1 Bellomont to the Board of Trade, C.C. $1697-8,472$.

2 Ib. 473 .

3 Randolph to the Board of Trade, ib. 521 .

4 Bellomont to the Board of Trade, C.C. I699, I16. ${ }^{5} \mathrm{Ib} .740$.

- Bellomont to the Commissioners of Customs and Colonel Quary to the Board of Trade, C.C. $1697-8,573,786$.

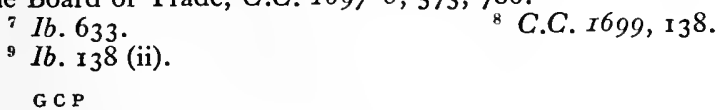


measures against illegalities in trade were likely to gain active support in Pennsylvania, for hostility did not stop short with abuse. The justices opposed the courts of admiralty as enemies of 'the Governor and the Friends'; and the attorneygeneral refused to prosecute ${ }^{1}$. Quary bombarded the Council of Trade with his accounts of abuses, and appeals for help, stating at one time that he had traced a number of pirates, but could not lay his hand on them because the government would not give him men: 'There are 7000 men, capable to bear arms, yet no militia or any means to serve the King,' all of whose servants were growing more uneasy at the neglect with which their complaints were received; and, Quary went on, unless some action were taken, it would soon be impossible to get men to take duty, especially in the admiralty department, where there were no salaries ${ }^{2}$. By October I699 Quary was becoming desperate ${ }^{3}$; and Nicholson also had written urging the Board of Trade to act in the matter of Pennsylvanian laxity, for the sake of example to other colonies ${ }^{4}$. The same year the Board of Trade reported on the colony; deciding that LieutenantGovernor Markham had acted without the royal approval, and had connived at and encouraged illegal trade; and that Penn had, without authority, disallowed as regards Pennsylvania the act for preventing frauds in the plantations ${ }^{5}$.

\section{Suggestions to re-enforce the laws}

The disorders in trade and piracy became so marked at the end of the century that the home government was driven to busy itself with suggestions and laws to establish its authority on a stronger foundation. In January 1700 it was decided that pirates should be sent home for trial, with the modification that Bellomont, Nicholson and Blakiston-that is, the governors who could be trusted-might conduct trials in the colonies when they thought it advisable ${ }^{6}$. Three months later, it was again decided to have the offenders tried in the plantations; and pro-

1 C.C. 1699,138 .

2 Ib. 483 .

$3 \mathrm{Ib} .877$.

4 Nicholson to the Commissioners of Customs, $i b .450$ (iv).

5 Board of Trade to the Lords Justices, $i b .694$.

6 Board of Trade to the King, C.C. I700, 29, 30. 


\section{v] DEFECTS OF SYSTEM AND ADMINISTRATION I63}

vision for this was made by an act for the suppression of piracy, which Parliament

having in view the refractoriness of New England and the other Plantations, has framed...extending to all the Plantations and other foreign parts, by which those of New England may perceive that where the public good does suffer by their obstinacy, the proper remedies will be easily found here ${ }^{1}$.

This act was brought in, according to the Board of Trade, because that body, being sensible of great irregularities in the proprietary and charter governments not only in regard to illegal trade and piracy, but otherwise, had required governors to receive royal approbation; this had not been complied with, nor had the security been given which ought to have accompanied the receiving of approbation, so that without provision by statute, "we do not see anything capable of reducing them to more regular compliance with their duty in reference to the Trade of England ${ }^{2}$.'

\section{The climax of evasion}

In the colonies meanwhile, the end of William's reign saw the climax of piratical activity. Virginia was by this time conducting its trade by a system of convoys precisely as in time of $w^{3}{ }^{3}$. 'All the news is the swarming of pirates, not only on these coasts but all the West Indies over, which doth ruin trade ten times worse than a war,' wrote Quary ${ }^{4}$. 'Hardly a ship doth come through the gulf or on our coast but is plundered'; this from Carolina ${ }^{5}$. 'Here in New York they run all the goods they can'; whilst in Massachusetts,

some gentlemen of the council expressed great discontent at the Acts of Trade and Navigation, that restrained them from open free trade to all parts of the world; they alleged that they were as much English as those in England, and thought they had a iight to all the privileges that the people of England had ${ }^{6}$.

1 Board of Trade to Bellomont, C.C. I700, 312.

2 Board of Trade to the House of Commons, ib. 244.

3 Minutes of Council of Virginia, ib. 395.

4 Colonel Quary to the Board of Trade, $i b .500$.

5 Governor Blakiston to the Earl of Jersey, $i b .52 \mathrm{I}$.

6 Bellomont to the Board of Trade, ib. 953. 
In 1701, Mr Larkin, commissioned to arrange for the trial of pirates under the recent act, reported also from Boston:

As to the laws of England they abhor the very thought of them.... Scarce a merchant here but what is guilty of carrying on an illegal trade, and the Courts protect them in it, for judgment is generally given against the King....Truly, I believe they would have been much better pleased if your Lordships had sent them an Act of Parliament for encouragement of so beneficial a Trade ${ }^{1}$.

Nicholson in Virginia set a notable example of determination on behalf of authority. A large pirate ship being reported near at hand, Nicholson immediately went on board H.M.S. Shoreham, and tackled the intruder.

The fight continued from 8 a.m. till 5 p.m., in all which time he never stirred off the quarter-deck, but by his example, conduct and plenty of gold...made them fight bravely till they had taken the pirate ship with roo odd prisoners, the rest being killed. A few more such expeditions, brave and generous actions from other governors would quickly clear these coasts of pirates,

wrote Quary, bringing also the evidence of prisoners to shew that but for Nicholson the pirate would have been allowed to escape ${ }^{2}$. In November however Bellomont was writing that, though 'there was too much unlawful trade, that from Madagascar seems to be at a stand at present, and I think piracy too is in its wane ${ }^{3}$.' Larkin confirmed this, as far as piracy was concerned, at the end of $1701^{4}$.

\section{The West Indies}

The West Indies throughout this period were chiefly concerned with the depopulation and loss of trade due to the war, and their urgent necessities took precedence at times of the requirements of the navigation laws. Jamaica early proposed pardon for pirates who should give security in land for their future good conduct ${ }^{5}$. This island had lost many men, especially seamen, owing to the earthquake and sickness, to em-

1 George Larkin to the Board of Trade, C.C. I7OI, 945.

2 Quary to the Board of 'Trade, C.C. I700, 500.

3 Bellomont to the Board of Trade, $i b .953$.

${ }^{4}$ Larkin to the Board of Trade, C.C. I7OI, I I3I.

$5 \mathrm{~J}$. Povey to Robt. Holmes, Lord Inchiquin to the King, etc., C.C. I690, 702-5. 
pressment for royal ships, and to Inchiquin's policy with regard to the rewards of prize ships ${ }^{1}$. In 1695 it was stated that Spanish ships traded openly in Jamaica, in defiance of the Laws of Trade; thereby obtaining the best negroes from Africa ${ }^{2}$. The following year, Beeston wrote that pirates had arrived in the Bahamas with treasure, and had sent to him privately to see if he would pardon them, in which case it would be worth 'a great gun' $(£ 20,000)$ to $\mathrm{him}^{3}$. In fact the state of Jamaica made it difficult to avoid some illegal trade, there being 'no money, no Assiento nor trade, nor other way to get anything ${ }^{4}$ '; so that the wants of the people obliged them to encourage all importers ${ }^{5}$. In 1697 there were great difficulties about money, the treasury was in debt and all things excessively dear; people could not sell their produce because there were not ships to carry it away ${ }^{6}$. In 1698 however Beeston wrote that there were no pirates in Jamaica, except some French who preyed upon the island, nor should any be suffered to come. The laws of Jamaica had been cited as an example in the new act concerning trade to the plantations ( 1696 ), and the people were 'much pleased that the island which formerly had the greatest name for privateering in these parts should now have its laws made an example to the rest of the King's dominions ?.'

\section{Barbados}

In Barbados depopulation was the great cry. In $169 \mathrm{r}$ the great need of white servants was put forward ${ }^{8}$. For heavy mortality had carried away great numbers; and the difficulty was increased by the repeal of the act concerning the participants in Monmouth's rebellion, in whose case a curious situation had arisen through the revolution. The prisoners from Monmouth's army had been deported to Barbados and sold into servitude $i 0$ the planters, who bought them on con-

1 Representation of Fulke Rose, C.C. $1693-6$, 931 .

- Representation of George Kast to the King in Council, ib. 2217.

3 Beeston to the Board of Trade, C.C. $1696-7,40$.

4 Beeston to Blathwayt, ib. 103.

- Beeston to the Board of 'Trade, ib. 130. $I b .1318$.

:C.C. $2697-8,55 \mathrm{I}$.

8 Address of Council and Assembly to the King and Queen, C.C. $1689-92$, 1923. 
dition that their possession was fixed by act of parliament at ten years or more. The repeal of this act would therefore defraud the planters of half their bargain; and a compromise was ultimately effected to improve their condition but preserve their labour ${ }^{1}$. In 1692 a sad account of the colony was sent to England, the dearth of white servants which handicapped its trade in peace being greatly aggravated by the war. The proportion of men formerly sent to fight from a parish was now greater than the total number of men in it $^{2}$. Such a state of need encouraged complaints, and as usual the $4 \frac{1}{2}$ per cent. duty on sugar exported was vigorously attacked, as usual also without effect ${ }^{3}$. In 1695 a case was quoted to shew that ships could land negroes at night before reporting, and that such traders would not scruple to assault the party of authority ${ }^{4}$; in 1698 a description related how goods were loaded in small bays and creeks and carried aboard; and in 1699 the Barbados government requested two men-of-war to enforce the Acts of Trade. Meanwhile Governor Grey carried out his duty as best he could with a ' heavy, crazy vessel, miscalled a cruiser ${ }^{5}$.' It would appear that, after the Peace of Ryswick, either illegal trade increased in volume, or the authorities became more rigorous-probably both causes operated to produce the increasing number of cases reported and methods described. In 1699 the collector of customs was complaining of open breaches of the laws of importation; and he had seized all offending vessels with the result that claims for nearly $£_{10,000}$ had been made against him, and one customs officer arrested, the others trying to resign their posts. The governor however publicly declared his support of the laws of trade and of the customs authorities-apparently not an unnecessary procedure-and obtained the release of the imprisoned collector ${ }^{6}$.

1 Board of Trade to Kendall, C.C. $x 689-92$, I 193 .

2 Representation of Barbados Agents, $i b .2449$.

3 Ib. 473, 2449.

4 Russell to the Board of Trade, C.C. $1693-6$, 1807.

5 Governor Grey to Secretary Vernon, C.C. I699, 72.

${ }^{6}$ Commissioner and Collector of Customs at Bridgetown (Barb.) to the Commissioners of Customs, $i b .476$. 


\section{Leeward Islands}

The Leeward Islands also shared the general depopulation and loss of trade ${ }^{1}$; and beyond the charges brought against Codrington afford little evidence of an extensive irregular trade during the war. In 1698 however Codrington himself had to suspend the lieutenant-governor of Nevis and the deputygovernor of St Kitts for not taking the oath in connection with the navigation laws as required by the act for regulating frauds ${ }^{2}$. St Kitts had apparently fallen into bad ways since its re-settlement after the French occupation; and the younger Codrington's account was not encouraging:

The disorder in trade is so great that I almost deplore of doing any good in it, and there is so much ignorance and laziness or corruption in Naval or Customs officers. I [know] a hundred things are done every day which I cannot possibly prevent, prejudicial to the trade and interest of England ${ }^{3}$.

\section{Bermuda and the Bahamas}

In Bermuda and the Bahamas one would expect fronı the general disturbance of political affairs that irregularities would be prevalent; and there are many suspicious incidents during the period. In the Bahama Islands the governor, Nicholas Trott, who had previously figured in cases of irregular trading in Bermuda ${ }^{4}$, was in 1696 charged with allowing pirates to land there in consideration of presents, and of taking part of the cargo $^{5}$; and he was therefore recalled ${ }^{6}$. In 1699 his successor Webb-who incidentally supported Trott ${ }^{7}$, as Trott supported his predecessor, Cadwallader Jones, an equally shady character $^{8}$-left his government for America, and was robbed in Virginia of $£ 7000$ in gold and $£$ rooo in goods. Bellomont suggested the inquiry how he had continued to make $£ 8000$ during a stay of two years in the Bahama Islands ${ }^{9}$.

1 Memorial of Agents to the Board of Trade, C.C. ${ }^{6696-7,200-1 . ~}$

2 Codrington to the Board of Trade, C.C. $1697-8,231$.

${ }^{3}$ C.C. IYOI, $40 \mathrm{r}$.

${ }^{4}$ Richier to the Board of Trade, C.C. $1689-92,1843$.

5 Additional instructions to Nicholas Webb, C.C. 1696-7, 434.

${ }^{6}$ Randolph to the Board of Trade, $i b .542$.

7 Case of Nicholas Trott, C.C. I697-8, 928.

8 Petition of Thomas Bulkeley to the King, C.C. $1696-7,681$.

9 Bellomont to the Board of Trade, C.C. $1699,746$. 
In Bermuda the sheriff was sued in 1692 for $£ 3000$, because of his seizure of a ship by order of the governor, and he was likely to be ruined by the action, he of course claiming that the judge was partial and the jury packed ${ }^{1}$. The following year Governor Richier was condemned, although unheard, for illegal trading ${ }^{2}$; and the unsavoury quarrel between him and his successor, Goddard, began. By r699 Bermuda, according to the new governor, Day, was rigidly enforcing the Laws of Trade; a naval officer had been appointed under bond of $£$ iooo and was apprehending pirates, for which an act had been specially prepared $^{3}$. Randolph however visited the island as surveyor, and peaceful conditions came to an abrupt end. According to Randolph, Day refused to recognize his collector, since the naval officer had just been appointed-the importance of the distinction lying in the fact that the collector was appointed by the English customs authorities or their deputy, and the naval officer by the governor. The protesting collector was threatened by Day ${ }^{4}$; and shortly after Randolph was committed to prison on the charge of "writing and contriving certain false and dangerous papers, words, reports and expressions, by him secretly and maliciously spoken and expressed towards his Excellency ${ }^{5}$,' The Board of Trade considered the imprisonment illegal and after applying to the Lords Justices for his release, severely reprimanded Day for his 'unexampled presumption,' the 'unwarrantableness of his proceedings,' and 'illegality and prejudice to his Majesty's service ${ }^{6}$ ' 'The governor however postponed the order after receiving it and Randolph was not released until January $1700^{7}$, having spent over six months in prison. It is typical of his character that on the very day of his release he seized a vessel and prosecuted it (unsuccessfully) in the court of admiralty ${ }^{8}$.

1 John Hubbard to the Earl of Nottingham, C.C. $1689-92,2156$.

2 Order in Council and petition of Edward Richier, C.C. $1693-6$, 4, ro.

3 Governor Day to the Board of Trade, C.C. $1699,262$.

4 Randolph to the Board of Trade, $i b .392$.

5 Commitment of Randolph, ib. 393.

6 Board of Trade to Day, ib. 658 .

7 Randolph to the Board of Trade, $i b$. ro86.

${ }^{8}$ Toppan, Ed. Randolph, Vol. II, p. 166. 


\section{The treatment of customs officers}

The treatment of customs officers in fact throws much light on the attitude of the colonies to the Laws of Trade and the English authority. Randolph himself is a standing example of a life long conflict between local and central administration. Arrested in Virginia ${ }^{1}$, New York, Pennsylvania and Bermuda, he may have been largely to blame for his own misfortunes, but he was at least consistently supported without qualification by the home government. Bellomont had great difficulty in finding suitable customs officers. The post was thankless, and was not made easier by such protests as that of Massachusetts against the right of appeal by customs officers from the decisions of local courts to England ${ }^{2}$. In I 699 Bellomont appointed one Townsend as collector for Nassau Island, with a salary of $£ 3^{\circ}$ a year and one-third of the seizures. Within a month he and his sureties came and begged his release from duty since 'though most of that town were his near relations, yet he was threatened by them to be knocked on the head, and he had already suffered many abuses, insomuch as he was in fear of his life.' 'The governor also offered one of the lieutenants of the New York companies $£$ roo a year with horses and men to be riding surveyor of Nassau Island, but he "though accounted a brisk man, and ready to starve for want of his pay and subsistences, told me in plain terms that he thought it too hazardous an undertaking for him $^{3}$.' In Pennsylvania, during the same year, Colonel Quary with much difficulty persuaded the customs officers to continue in the execution of their respective duties until he could hear from home ${ }^{4}$.

In Barbados, William Sharp, the commissioner and collector of customs at Bridgetown, described the boast of the traders and planters there, that

they will make it not worth any man's while to serve the King here, and if they put in execution the unreasonableness, as they call it,

1 Maryland Archives, viri, pp. 432, 483-554.

- Petition of Lieutenant-Governor and Council of Massachusetts to the King, C.C. $1697-8,677$.

3 Bellomont to the Board of Trade, C.C. I699, 38I.

4 Quary to the Board of Trade, $i b$. $13^{8}$. 


\section{ECONOMIC ASPECTS OF COLONIAL POLICY [CH.}

of the Acts of Trade and Navigation, it shall cost them a thousand pounds sterling but they will either get them turned out at home or ruin them here.

They threw one officer into the common gaol for carrying out his duty, and intimated that the rest would soon follow him; several others, wrote Sharp,

in the greatest dread and concern imaginable brought me their commissions, saying it was hard indeed a man must either be forsworn, betray his trust, or be thrown in to a gaol and ruined by these... most dangerous sort of people ${ }^{1}$.

\section{(c) The Trade Laws and Scottish Activity}

\section{Scottish traders}

Throughout William's reign there is much evidence of Scottish activity in the colonies; and this evidence is focussed in the history of the Darien scheme, which was responsible for an open declaration of English policy in colonial affairs towards her northern neighbour. Before the scheme materialized the Scottish nation had many representatives in America. In New Jersey the principal traders were Scots, reported Governor Basse $^{2}$. In New York, there were Scots enough to be sureties for returning members of the Darien expedition ${ }^{3}$. Randolph had 'never observed so many Scotsmen as are now in Pennsylvania, and so I am informed in Virginia and Maryland ${ }^{4}$.' The legal position of Scotchmen was not clearly understood. Maryland condemned ships that had Scottish owners, unless they were resident in England or Ireland ${ }^{5}$; and the law officers were called in to settle other disputes, deciding that Scotchmen were natural-born subjects of England within the meaning of the Acts of Trade, and could therefore engage in trade with the plantations ${ }^{6}$. Their activity however was not confined to lawful trade, and in 1695 Randolph submitted some suggestions

1 C.C. 1699,476 (ii).

2 Governor Basse to the Board of Trade, $i b .512,514$.

3 Bellomont to the Board of Trade, $i b .878$.

4 Ib. 450 (ii). Colonel Quary also emphasized the large share of Scotchmen in running goods in Pennsylvania (C.C. I70o, I90).

5 Biakiston to the Board of Trade and Sansom to Popple, ib. 433, 763 .

- Law officers to Popple, ib. 71, 579 (xvi). 
for preventing illegal traffic between the tobacco plantations and Scotland, in which he claimed that the Scots 'counterfeited' Englishmen, and also planted colonies in places not inhabited, making treaties of peace and commerce with governors and proprietors and paying an acknowledgment to the King. These settlers served as a centre for other trading Scots. Randolph therefore proposed that South Carolina and the Bahamas should be taken over by the crown, that North Carolina should be joined to Virginia, and the Delaware country to Maryland; and that no one should be allowed to alienate to any Scot any island or plantation between $32^{\circ}$ and $44^{\circ}$ of latitude ${ }^{1}$. As a result of this appeal, the King strictly enjoined the governors to suppress Scottish traders, but the rest of Randolph's plan fell to the ground ${ }^{2}$.

\section{The Darien scheme}

The main features of the Darien scheme, its great popular support, and the results of its failure seen in the union of Scotland and England, are well known. Setting sail in the autumn of 1698 under a charter from the English government, stipulating certain conditions, the expedition finally settled at the isthmus of Darien and the English government began to realize the importance of the event. In May 1699 the Board of Trade issued a report on the Scottish settlement ${ }^{3}$, in which they recapitulated the articles of the charter binding the Scots not to settle on any inhabited place without consent of the inhabitants, nor upon places possessed by any European prince or people. The settlers claimed that the spot they had selected was never before possessed by Spaniards ${ }^{4}$; but the Board of Trade was of opinion that the Spanish claim to the territory was valid, and for that reason others had refrained from colonization there. If that was so, the Scotch had violated their charter, and also the Anglo-Spanish treaty of 1670 . This report was no doubt accurate, but it is worthy of remembrance that in respect of the latter charge--that of breaking the Anglo-

1 Randolph to the Commissioners of Customs, C.C. I693-6, 2187.

2 Board of Trade to Governors of Colonies, $i b .2273$.

3 Board of Trade report on Scottish Settlement, C.C. I699, 456.

4 Memorial on behalf of the Company of Scotland, ib. 434 (ii). 


\section{ECONOMIC ASPECTS OF COLONIAL POLICY [CH.}

Spanish treaty - there is no reason to suppose that the Board of Trade objected to that agreement being infringed: in fact, they had in 1697 themselves advised the seizure of Golden Island and a port on the mainland for the crown ${ }^{1}$, which would have been at least an equal violation. Certainly the King of Spain regarded the settlement at Darien as 'a mark of little friendship and a rupture of the alliance between the two Crowns ${ }^{2}$.'

The settlers meanwhile had emerged victorious from a skirmish with the Spaniards; and the enterprise was appealing to the national spirit throughout the colonies. Scotchmen in the Jerseys declared that if the King interrupted the settlement it would endanger a rupture between the two nations. Governor Basse of New Jersey was of opinion that 'Caledonia promises to be of great prejudice to our nation and revenue, and to be the emporium of the trade and riches of America, connecting the East and West Indies, and tapping the wealth of Mexico and Peru $^{3}$.' In January I699 orders had been issued to all the colonies that help should not be given in any way to the new settlement ${ }^{4}$. This order was formally proclaimed in Barbados, Jamaica, New York, New England, New Jersey, Maryland and Virginia ${ }^{5}$; the Spaniards however refused to differentiate between the two nations under one crown, and injured British shipping indiscriminately ${ }^{6}$. The French also urged Spain to activity, telling them that the proclamations against assistance were merely a blind to cover joint action-that the English and Scotch were one ${ }^{7}$. Spain certainly believed that England gave help to the colonists, in spite of assurances to the contrary ${ }^{8}$; and it was difficult to contradict that belief, with the existing numbers of Scots in the plantations, and the ease with which the ordinary regulations of the navigation system were evaded. The most that can be said is that help was not given officially. The Scotch settlement however was not destined long to with-

1 C.C. 1699 (Preface, p. viii).

2 Memorial of the Spanish Ambassador, $i b .434$ (i).

3 Basse to the Board of Trade, $i b$. 5 I4.

4 House of Lords MSS., New Series, 1486.

${ }^{5}$ C.C. $1699,253,384$ (x), 334, 433, 505, 514.

6 Beeston to the Board of 'Trade, etc., $i b .85$, 149 , etc.

$7 \mathrm{Ib} .505$.

${ }^{8}$ Deposition of Dominick Arthur, C.C. $I 700,3_{3} 6_{3}$ (ii). 
stand the attack of Spain; and when that country brought up a force of 15 ships with a land army, the main party of settlers, weakened by famine and disease, surrendered, leaving the Spaniards in possession ${ }^{1}$.

\section{(d) The Economic Development of the Colonies}

\section{Proposal to take in the Hinterland}

During William's reign suggestions are put forward of development in several directions, some of great interest for later history, others relatively unimportant, but all breaking new ground, at a time when it was by no means clear what the future position of the North American continent was to be. At the beginning of the French war, the danger of French aggression in the region west of the line of English colonies became manifest, since France now controlled both the northern extremity in Canada and the southern outpost in Louisiana. Some English merchants therefore saw possibilities of gain in a rival scheme of commercial aggression, and in 1689 requested a patent for the country lying in

the centre of the Northern part of America, between $36 \frac{1}{2}^{\circ}$, the Northern boundary of Carolina, and $46 \frac{1}{2}^{\circ}$, the Southern boundary of Canada; on the East, the western bounds of Virginia and Maryland, and to the West the Pacific or Southern Sea.

The chief advantages of this development were urged to be that the French would be deprived of some of the richest branches of their commerce, the fur trade being cut off, which was worth $£ 5^{\circ}, 000$ to them; that great profit could be made from the 'Pesikions or Sibils, whose hair is like Spanish wool'; and that there was great mineral wealth and good dyeing woods ${ }^{2}$. In September 1690 a draft charter appeared for incorporating a company on these lines ${ }^{3}$; but after this the scheme seems to have lapsed.

\section{A remedy for New England}

If however possession of the hinterland seemed to be one of the necessities of development, a more generally recognized

1 News sent from New York to Nicholson, C.C. 1700,533 (iv).

2 Account of country for which a patent is desired, C.C. $1689-92,680$.

${ }^{3}$ Draft Charter, $i b .2775$. 
deficiency in the economic life of America-considered from the standpoint of English statesmen-lay in the position of New England, which had hitherto been considered as a settlement incompatible with the main principles of the navigation system. It produced little or none of the commodities which England desired, and also threatened to develop on the same commercial lines as the mother country, by its rivalry doubly defeating the ends of English trade policy. Thus several efforts were made to transform New England into a colony producing some commodity useful to the home country. In r697 an attempt was made to form a company for working copper mines there. A petition followed from merchants and others concerned in New England trade stating that such an application had been made to monopolize the whole trade of New England by the ruin of the country people ${ }^{1}$. The proposed company replied with the suggestion of combining the production of naval stores with its mining activities, and promised to substitute colonial for foreign productions, thereby greatly increasing New England trade ${ }^{2}$. The agent for Massachusetts opposed the scheme, saying that the same proposal had been rejected under Charles II and James II and that if any new reasons could be urged in its favour, Massachusetts would counter them ${ }^{3}$. The main objections were grounded on the failure of previous efforts, on the idea of monopoly, since the company offered only to produce what individuals could, and moreover other corporations had long survived in the face of complaint ${ }^{4}$.

\section{Naval stores}

The development of which there was most discussion and report was the production of naval stores (masts, pitch, tar, rosin and similar products) especially in New England, by which the monopoly of the Baltic countries would be overthrown, and a supply would be guaranteed for time of war. Brewster, writing in 1695 , pointed out that New England was superior to any of the Northern Crowns for timber, masts, pines and

1 C.C. $1696-7,894$.

2 Memorial of subscribers and undertakers, $i b$. I 150.

3 Sir Henry Ashurst to the Board of Trade, $i b$. 1328.

4 Ib. $136 \mathrm{r}$. 
firs to make pitch and tar, for soil to raise hemp, and was good enough for making iron. If this could be developed, he maintained, 'it would make New England of the most useless and unprofitable plantation of this nation the best and most advantageous ${ }^{1}$.' In 1696 Randolph spoke of the large possibilities of New England in ship-building and naval stores, little cultivated, as also in Maryland, for want of a market ${ }^{2}$. Another letter, from a New England merchant, confirmed the proposal ${ }^{3}$, and later in the year commissioners were appointed to consider the matter ${ }^{4}$. Bellomont on his arrival entered heartly into the project, and indeed gave it life. After receiving a report from the joint commission of representatives from the Navy Board and New England, in which they expressed themselves well satisfied with the produce ${ }^{5}$, his next step was to propose that in the Albany and Senectady area soldiers should be employed on cultivation of such products, with $4 d$. a day extra pay, and after seven years should receive grants of land, inalienable, because of the natural tendency for them to gamble it away ${ }^{6}$. New Hampshire, which Bellomont accused of 'ploughing with his heifer,' proposed the same scheme for Maine ${ }^{7}$. These proposals however needed sanction for the expenditure involved, and implied the speedy revocation of Fletcher's grants of land; and in the meantime Bellomont forbade the cutting of trees suitable for masts ${ }^{8}$; and attempted to stop a shipload of timber leaving New England for Portugal, fearing that it would eventually reach France; but finding no law to warrant his action, he reluctantly allowed it to proceed ${ }^{9}$.

In 1700 Bellomont was still pursuing his scheme: 'Tar, masts and timber may be produced for half what they cost at present, and the whole Eastland trade for Naval stores, except flax and hemp, may be turned this way ${ }^{10}$ '' The produce was again in-

1 Brewster, Essays on Trade and Navigation, Part I (I695), p. 84 .

2 Randolph, 'Discourse how to make the plantations more beneficial and advantageous to the Kingdom' (C.C. I696-7, 108).

3 Considerations offered by Colonel Charles Lidget, $i b$. 172 .

4 Board of Trade to the King, $i b .318$.

5 Mr Bridges to Bellomont, C.C. I699, 769 (xvi).

6 Bellomont to the Board of Trade, $i b .267$.

I $\mathrm{Ib} .8 \mathrm{I} 7,894$.

Ib. 986 .

$8 \mathrm{Ib} .878$.

${ }_{10}$ C.C. $I 700,466$. 
spected with varying results, some experts loud in praise, others decrying it as compared with the stores obtained from the Baltic countries $^{1}$; and Bellomont suspected the prejudice and opposition of the Eastland merchants ${ }^{2}$. A private company now attempted to step into the breach, but the Board of Trade demanded too large a guarantee ${ }^{3}$. The board also suggested that the soldiers be forthwith employed as Bellomont proposed"; but the governor reminded them that this was not practicable until he received permission, by an act which had not as yet received the royal assent ${ }^{5}$, to revoke the large grants of land made by Fletcher, since 'the King has not an acre of land or a tree in the province'; and moreover the soldiers had no pay ${ }^{6}$. Bellomont however pushed on the scheme on his own credit, sending at his own cost a shipload of timber as specimens shortly before his death, which event prevented his knowing that the ship was wrecked off Cornwall, and the whole cargo lost? .

Bellomont, although not going so far as the company which proposed to settle the interior, also realized the French danger in the hinterland. His remedy was for the Indians in that region west of Virginia and Maryland to be engaged in trade by those colonies, and thus bound commercially to the English interest against the schemes of France. To this end he asked for encouragement of the beaver trade, which had suffered by that dictate of fashion which discouraged beaver hats in England ${ }^{8}$. The proposal did not meet with hearty support from the colonies concerned, although the Board of Trade approved 'provided it do not interfere with the planting cf tobacco, which in those provinces is to be preferred before all things ${ }^{9}$.'

\section{Manufactures}

The Board of Trade however when it reiterated this fundamental principle of English colonial policy, had already been

1 Various reports to the Board of Trade, C.C. 1700,117 (i, ii); 233 (ii).

2 Bellomont to the Board of Trade, $i b .580$.

${ }^{3}$ Hayne and others to Popple, $i b .333$.

4 Board of Trade to Bellomont, ib. 307.

5 Bellomont to the Board of Trade, $i b .953$.

7 C.C. I7OI, $146 . \quad{ }^{8} \mathrm{Ib} .3^{8}$.

6 Ib. 845 .

' C.C. I700, 307 . 
faced with a more dangerous development in the economic life of the same colonies, Virginia and Maryland. In 1697, Andros had remarked casually that owing to the shortage of supplies from England a little linen and woollen manufacture and shoemaking was growing up there, but that this was inconsiderable compared with the tobacco industry; the volume of trade remaining almost constant in the previous years ${ }^{x}$. The English government however realized that this new departure was far from insignificant, and directed its attention to the question of manufactures in the American colonies, as in Ireland, where a similar process was developing. As early as November and December I688, the Assembly of Maryland, 'considering the great quantities of Linen and Woollen cloth brought in, for want of like policy and industry as other countries have attained unto' enacted that a system of bounties, payable in tobacco, by the commissioners of the County courts, should reward the manufacturers of every yard of woollen and linen cloth of standard width and that special prizes should be given for the best piece of each at a certain fixed size. Moreover encouragement on similar lines was to be given for the sowing and making of flax and hemp, whilst fines were imposed on the exportation of wool ${ }^{2}$. By 1699 the manufacture of woollen and linen goods had become notable enough to attract the notice of the legislature of England. In January of that year, the Board of Trade wrote to the House of Commons that

Our intent in settling our Plantations in America was that the people there should be only employed in such things as are not the production of this kingdom, except for provisions for themselves and their neighbours....Yet they here applied themselves to much besides other things to woollen manufacturing which in its proportion is as prejudicial to the Kingdom as those in Ireland,

wherefore it was submitted that a like prohibition be made. The draft of such a clause was agreed on, and Blathwayt desired to present it to the committee of the House ${ }^{3}$. It was therefore decreed by an act of Parliament that, whereas

1 Andros to the Board of Trade, C.C. $1696-7,956$.

2 Maryland Archives, xill, p. 220.

3 Board of 'Trade to the House of Commons, C.C. I699, 32. 
wool and woollen manufactures are the greatest and most profitable commodities of this Kingdom, on which the value of lands and the trade of the nation do chiefly depend... and great quantities of the like manufactures have of late been made and are daily increasing in the Kingdom of Ireland and in the English plantations in America, and are exported from thence to foreign markets, heretofore supplied from England, which will inevitably sink the value of lands and tend to the ruin of the trade and the woollen manufactures of this realm....

No wool etc., or woollen manufactures whatever, being of the product or manufacture of any of the English plantations in America shall be loaded or laid on board on any ship or vessel...within any of the said English plantations...or upon any horse, cart, or other carriage, to be conveyed out of the...plantations to any other of the said plantations;

this regulation to be enforced by the penalty of fines and the governors to be cautioned concerning its due observance ${ }^{1}$. Thus appears the first mention of American woollen manufactures in the Statute Book, and with it the threat of real economic rivalry between the New World and the Old. It had previously been complained that New England by supplying provisions to the other colonies was usurping the rights of the mother country; but provisions of food were admittedly in a class by themselves, and some of the more prudent statesmen and writers confessed that there might even be advantage in having a supply of necessaries near to the market for them. The rise of manufactures however would be a distinct and unmistakable usurpation of commercial prerogative. Thus, to the conflict of political interests between the colonies, now growing into states, and the mother country, there was added a conflict of commercial interests; and the two eventually brought about the downfall of the navigation system by destroying the colonial relationship.

1 Statutes at Large (Io and II William III, c. I0); see also Macpherson, op. cit. Vol. II, p. 705. 


\section{CONCLUSION}

\section{The three problems of policy}

It is thus evident that during the reign of William III developments took place in the three principal branches of colonial government. In the sphere of foreign relations the revolution brought with it the war with France-a war which would no doubt have come without it, but the outbreak of which was hastened and made more decisive by the accession of William. This war brought to the front the problem of colonial defence, a question to which no answer was given until the separation; and the burden of defence was therefore sustained inadequately, and the organization of resources imperfectly carried out. There was in short no final responsibility, but mutual dissatisfaction. In the second place, political affairs now began to centre around the conflict for power between the crown and the local assemblies. The increase of royal power at the expense of proprietary governments was a necessary step in the political development of the colonies; but it merely cleared the ground for the keener struggle between centralization and local government, represented in most cases by the governor and the assembly respectively. The colonies undoubtedly wished for a larger share of political independence than England was prepared to concede, even if she ever grasped the meaning of the conflict. They were deeply imbued with English political ideals, especially with the hatred of tyranny; and, in allowing no outlet-except what was forced-for their political aspirations the English government began to assume in their eyes the position of tyrant. The landmarks of English liberties could therefore be quoted in support of American liberties. For, in the third place, in commercial affairs, the colonies were beginning actively to resent the system of government which regarded them solely as commercial settlements and ignored or opposed their political existence. The navigation laws were therefore widely attacked and evaded; and in one case at least the products of the home country were discriminated against ${ }^{1}$. In face of such opposition

1 C.C. $1702,122$. 
England sought to stiffen and maintain by force the system of restriction on which its entire colonial policy was based, and especially endeavoured to crush new developments of manufacture, which would rival English products and thereby destroy the basis of commercial and colonial policy.

\section{A new type of empire}

England was therefore required in her colonial policy to face and to solve three problems-the adjustment of defence, the constitutional position of the outlying states, and the commercial system in which they and the mother country should work together. But these are surely the main problems of empire in its modern sense-as opposed to the purely commercial empires of Spain, Portugal and Holland-provided only that the colonists in question are vocal, active and educated, which in this case they certainly were. Is it then too much to claim for the events of this period that they inaugurated that imperial system which is the peculiar feature of modern history, especially of British history? The English crown found itself in the difficult position of ruler over a number of settlements which were by this time something more than mere trading stations, and which had clear cut ideas of political independence and liberty. It had no experience of such a position, of the government of outlying states, constitutionally formed and demanding constitutional methods and constitutional development on the same lines as the English model, which had itself in the revolution taken one more of the steps by which it became the pattern for new communities. Never before-at any rate since medieval times-had such an empire existed. Moreover, with the methods of communication at its disposal at that time, the government of such an empire involved perhaps greater difficulties even than the later world wide spheres of government. The importance however lay in the fact that it was a political relationship that was needed, and in part was implied, to meet the growing needs of the states which began as trading settlements.

Originally, the empire of the old colonial system may have conformed-nay, it certainly did conform-to that type of 
empire which was based on trade and trade alone; but since, unlike the other trading empires, its members went out with definitely political ideas, it was faced with larger problems, and as it was unique in this respect, so also, failing to bring a new understanding to a new situation, it failed in a more signal, more dramatic collapse than they. And the measure of difference between that empire, its nature and its possibilities, and the other trade-empires, may be found in the present difference between the United States and the South American republics. 


\section{APPENDIX A}

\section{BIBLIOGRAPHY}

The following are the principal authorities which have been found useful on the subject:

\section{BIBLIOGRAPHY}

Andrews, C. M. and Davenport. Guide to the Material for American History in the British Museum, near London archives, and the Libraries of Oxford and Cambridge.

Andrews, C. M. and Davenport. Guide to the Material for American History in the Public Record Office.

Newton, A. P. The Study of Colonial History.

\section{CONTEMPORARY AUTHORITIES}

[The list is here small, on account of the preponderating importance of the Colonial State Papers, which include the bulk of correspondence and records for the period.]

Acts of the Privy Council, Colonial Series.

Archives of Maryland (Maryland Historical Society Publications).

Bacon. Essays.

Brewster, F. Essays on Trade.

Burnet. History of My Own Time.

Calendar of State Papers, Colonial Series (America and West Indies).

(Ed. Fortescue and Headlam for $1685^{-1702 .)}$

Calendar of State Papers, Domestic Series.

Child, J. A New Discourse on Trade.

Cовветt. Parliamentary History of England.

Hening. Statutes of Virginia.

Journals of the House of Commons.

Moll, Herman. Atlas.

Mun, T. England's Treasure by Foreign Trade.

O'Callaghan. Documentary History of New York.

SANSON. Atlas Nouveau, 1696.

Select Tracts (I029 E 15 in British Museum Reading Room Catalogue). Statutes at Large (Reign of William III). 


\section{SECONDARY AUTHORITIES}

(a) Works on various aspects of Colonial Policy

Andrews, C. M. The Colonial Period.

BEER, G. L. Origins of the British Colonial System.

BeER, G. L. Old Colonial System, 2 vols.

Befr, G. L. Commerical Policy of England towards the American Colonies.

Cunningham, W. Growth of English Industry and Commerce.

DiceY and RaIT. Thoughts on the Union between England and Scotland.

Dickerson, O. M. American Colonial Government, 1696-1765.

Eserton, H. E. A Short History of British Colonial Policy.

Egerton, H. E. Colonial Administration of Crown Colonies in the Seventeenth Century (Royal Historical Society Transactions, 4th Series, Vol. I, pp. 190 et seq.).

GrEene, E. B. The Governor in the English Colonies in America.

Greene, E. B. Provincial America.

Leroy-Beaulieu. De la Colonisation chez les Peuples Modernes.

Pownall, T. Administration of the Colonies.

SeEley, J. R. Expansion of England.

SMith, AdAm. Wealth of Nations.

(b) Biography

The Dictionary of National Biography is of use for members of the Councils of Trade, and for one or two outstanding characters such as Phips.

Toppan, R. N. Edward Randolph. (7 vols.)

(c) Histories of the Colonies generally and of separate Colonies

Barrow. Naval History of Great Britain.

Bowden, J. History of the Friends in America.

BrUCE, P. A. Economic History of Virginia. Institutional History of Virginia in the 17 th Century ( 2 vols.).

Cambridge Modern History. Vol. vil.

Channing. History of the United States.

Clarkson, T. Memoirs of William Penn.

CUNDAll, F. Studies in Jamaica History.

Doyle, J. A. The English in America (3 vols.).

Fisher, S. G. Men, Women and Manners in Colonial Times (2 vols.).

Fiske, J. Beginnings of New England.

FISKE, J. Dutch and Quaker Colonies in America.

FISKE, J. Old Virginia and her neighbours.

GaRdNer, W. J. History of Jamaica.

Hart, A. B. The American Nation: a History (especially AndRews, C. M. Colonial Self-Government).

Higham, C. S. S. Development of the Leeward Islands (I660-1689).

HILDRETH. History of the United States. 
Hughes, T. History of the Jesuits in North America (4 vols.). Hutchinson, T. History of the Province of Massachusetts Bay. Jeffrey, R. W. History of the Thirteen Colonies of North America.

Latané, J. H. Early Relations of Virginia and Maryland.

LoNG, E. History of Jamaica (3 vols.).

Lucas, C. P. The West Indies (Historical Geography of the British Colonies).

Macpherson. Annals of Commerce.

Oliver, V. L. History of Antigua.

Osgood, H. L. The American Colonies in the 17 th century ( 3 vols.).

Parkman. ('The French in Canada' series, especially Count Frontenac and New France under Louis XIV).

Penson, L. M. The London West India Interest in the Eighteenth Century (Historical Review, July I $92 \mathrm{I}$ ).

Pitman, F. W. Development of the British West Indies.

Pollard, A. F. The British Empire.

RAper, C. L. N. Carolina.

Rickman. Rhode Island (American Commonwealth Series).

Sanborn. New Hampshire (American Commonwealth Series).

Schomburgk. History of Barbados.

Smith, W. R. South Carolina as a Royal Province.

Tyler, L. G. The English in America.

VAN Rensselaer. History of the City of New York.

Winsor, J. History of America (7 vols.).

\section{APPENDIX B \\ THE DESPATCH OF TROOPS TO NEW YORK $1693-5$}

\section{An illustration of Administrative Method}

(The references in brackets are to the Calendar of State Papers, Colonial Series, 1693-6.)

1693. Dec. The King in Council orders 2 companies of 1 oo men each, and sufficient recruits to make the existing 2 companies up to $100 \mathrm{each}$, to be forthwith raised and sent to New York (754).

694. April. A Warrant is obtained for the 4 Companies, and for a chaplain, surgeon, storekeeper, armourer and two matrosses to be maintained out of the surplusage due to the $30 \%$ difference between English and New York money. (Each company to consist of I Captain, 2 Lieutenants, 3 Sergeants, 3 Corporals, 2 Drummers, Ioo Men.) (998.)

The King orders haste (1023).

May. Council of Trade inquire what shipping has been taken, and if it will be ready (ro6o).

The Admiralty direct the Navy Board to provide transport for 340 men $(1063-4)$.

The Victualling Board ask for numbers (1069).

(By this time 50 men have been raised (1070)). 
June. The Ordnance Board is interviewed about bedding (1077-80). The Council of Trade now inquires how many men can be sent off at once, as if they wait for the full number, the convoying ships and the merchant fleet will have gone (1079).

A Certificate of Arms wanting is sent to the Ordnance Board (1 1 104). The question is now raised whether the troops will have to go by Boston (II70).

July. The Victualling Board has had no reply to its question how many men are to be provided for (I I 68).

A warrant is now issued for the Hope to take two companies (1 1 71 ). August. The troops on their way to the place of embarkation are quartered in Petersfield Church, and a quarrel arises about damages and defilement between the military authorities and the town (r r 90 , I2r8).

November. The companies return to England after three months of hardship, sickness and loss in engagement with French privateers at sea. Of the 152 soldiers and 21 hands, not 40 had escaped a 'strange kind of illness, complaining much of their heads and backs' (1470, 1524).

1695. June. The troops arrive in New York from Boston (r902).

\section{APPENDIX C}

The population of the various colonies at the time of the revolution (I689) was approximately as follows:

\begin{tabular}{|c|c|c|c|c|c|c|}
\hline Massachusetts, & Mai & and & mo & $\cdots$ & 48,000 & \\
\hline Rhode Island & $\cdots$ & $\cdots$ & $\cdots$ & $\cdots$ & 5,000 & \\
\hline New Hampshi & e... & $\cdots$ & $\cdots$ & $\cdots$ & 6,000 & \\
\hline Connecticut & $\cdots$ & $\cdots$ & $\cdots$ & $\cdots$ & 20,000 & 79,000 \\
\hline $\begin{array}{l}\text { New York } \\
\text { New Jersey } \\
\text { Pennsylvania }\end{array}$ & $\begin{array}{l}\cdots \\
\cdots \\
\cdots\end{array}$ & $\begin{array}{l}\cdots \\
\cdots \\
\cdots\end{array}$ & $\begin{array}{l}\cdots \\
\cdots \\
\cdots\end{array}$ & $\begin{array}{l}\cdots \\
\cdots \\
\cdots\end{array}$ & $\begin{array}{l}20,000 \\
10,000 \\
12,000\end{array}$ & \\
\hline $\begin{array}{l}\text { Maryland... } \\
\text { Virginia ... }\end{array}$ & $\begin{array}{l}\cdots \\
\cdots\end{array}$ & $\begin{array}{l}\cdots \\
\cdots\end{array}$ & $\begin{array}{l}\cdots \\
\cdots\end{array}$ & $\begin{array}{l}\cdots \\
\ldots\end{array}$ & $\begin{array}{l}20,000 \\
58,000\end{array}$ & 42,000 \\
\hline Carolina ... & $\cdots$ & $\cdots$ & $\cdots$ & $\cdots$ & 5,000 & $\begin{array}{r}78,000 \\
5,000 \\
204,000\end{array}$ \\
\hline
\end{tabular}

(See Channing, History of the United States, F. 222 n.)

Of the West Indian Islands:

Barbados had in $1683,17,187$ free persons and 46,602 slaves; in $1712-14$, 12,538 free persons and 41,970 slaves. (See Pitman, Development of Brit. West Indies. Appendix.)

Famaica had in $1673,8,564$ whites and 9,504 negroes; by 1703 the negroes had increased to 45,000 . (See Long, History of famaica, I, p. 370.)

The Leeward Islands had in 1678, 4,769 white men, 3,227 negroes. (See Higham, Development of Leeward Islands, p. 148.) 


\section{INDEX}

Abenakis, 47

Admiralty Courts, 10, 126, 154

Albany, 3 I , 55, 80, 89, 107

Albemarle, Duke of, 40, I 39

Allen, Samuel, i i 8, 124-5

Andros, Sir Edmund, GovernorGeneral of New England, I I ; at the revolution, 13 et seq.; charges against, I7, III; Governor of Virginia, 37,76 , I I I-3; on manufactures, 177

Anguilla, 6I

Antigua, 60-I; defence in, 94-5; politics in, 133

Appeals to England, 102, $123^{-5}$

Ashurst, Sir Henry, I 10

Bahamas, under William III, 145-6; trade in, 167

Baltimore, Lord, proclamation of WilliamIII, 32 ; accusations against, 33 ; relations with revolutionary government, 34 ; relations with Crown, I 14

Barbados, under Charles II, 9; at the revolution, 38; and French war, $59,63,93$; and Irish, 59 ; Kendall's governorship, 136-7; Russell's, I37; Grey's, 138 ; trade in, $165-6$

Barbuda, 60

Basse, Governor, 172

Bath, Earl of, I00

Bayard, 27-8, I 28

Beeston, Sir William, 40, 59; and the war, $69-73,92$; his governorship in Jamaica, I40-2; and trade laws, I65

Bellomont, Earl of, superseded Fletcher, 83, II9; criticizes Fletcher, 88, 119 et seq.; and the Indian alarm, $85-8$; increased financial power, 89; land schemes, 90 , I2I, 175; naval stores, 175; rule in New England, $117-28$; on the state of justice, I22; on illegal trade, 160 et seq., 169 ; death of, 92 , I 27,176

Bermuda, under Charles II, IO; under William III, I42-5; trade laws in, 167

Blair, James, I 12
Blake, Governor of SouthCarolina, 147

Blakiston, Nathaniel, 9 I, 1 I 7

Blathwayt, William, 75, I 0 I, 1 25-6

'Blues,' see Bolton's Regiment

Board of Trade, and quotas, 9I ; Report of I696, 97; of 1697 , I 18 ; creation of new, roo; duties of, IOI; and manufactures, I77-8

Bolton's Regiment, 62, 66

Boston, revolution in, 14 et seq.; reasons for, I 5 et seq.; revolutionary government in, 19,21 ; beginning of war in, 48 ; Wheler's squadron in, 74-5

Bradstreet, Simon, I4, 49

Bridgwater, Earl of, I00, ${ }_{3} 8$

Cadaraqui, 87

Canada, attack on, 5I, 74-5

Capel, Sir Henry, Ioo

Carolina, 37, 102

Casco, 50

Chamberlayne, Willoughby, 38

Cheseldyn, Kenelm, 33

Church of England, 19 ; in Maryland, I I 7

Cloth, manufacture of, $177-8$

Codrington, Christopher, senior, 39 , 59-70, 74, 167; Leeward Islands under, I 32-6; charges against, 94I34

134 junior, succeeds his father, 94, I34; his governorship, $135^{-6}$, 147

Committees for Trade and Plantations, IO, 99 et seq.

Communications, IOI

Company of the North, 44

Coode, John, 33-5

Connecticut, and Quebec expedition, $5 \mathrm{I}$; and quotas, 58, 76-7, 79; letters to, 102 ; condition of, 109-10

Cornbury, Lord, I28, I3I

Copley, Lionel, I $14,{ }_{5} 8$

Copper mining, 174

Darien scheme, $171-3$

Day, Governor of Bermuda, I44-5, I 68

De Blenac, Governor of Martinique, $60,66,69$ 
Defence, during the revolution, 20, 30-I, 47

Delanoy, 79, 110

Dellius, 90

Denonville, 12, 42

Des Gennes, 95

Dongan, Governor of New York, 12, 28,42

Dowaganhas, 84

Dudley, Joseph, I4, I06, I3 1

\section{East Jersey, $5^{8}$}

Five Nations, see Iroquois

Fletcher, Benjamin, Governor of New York, 38 ; arrival, 56 ; measures for defence, $58,75-80,82$; criticized by Bellomont, 88 ; and Phips, 58 , I $3-7$; at Wheler's arrival, 75; character of, 106; governorship in New York, I06-I I; charges against, III, I60; land policy, I 21

Fox, Colonel, Deputy-Governor of St Kitts, 94, 135

France, Colonial relations with, under James II, I 2 ; under William III, 44 et seq.; reasons for war, 46 ; during interval 1697-1702, 83

Frauds, Act for Preventing, 122, I 53

Frontenac, Governor of French Canada, 12, 47-8, 51, 76, 85

George, Captain, 17, 20, 156

Goddard, Governor of Bermuda, I 43-5, 168

Gouverneur, Abraham, 105, II

Grey, Governor of Barbados, 93-5, 138

Guadeloupe, attacks on, $63-4$

Hallett, Colonel, ${ }_{3} 6$

Harvard College, I 22-3

Haskett, Governor of Bahamas, 146

Hill, Abraham, Ior

- Lieut.-Governor, 6o, 65

Hispaniola, 70

Hudson's Bay, 44, 46, 83

Huguenots in Virginia, 113

Illegal trade, ${ }_{5} 6-70$

Inchiquin, Earl of, 40,140

Indians, French, $48,57,80,85^{-8}$

Ingoldsby, Major, 106

Irish, 59-6I, 67

Iroquois, $12,48,53,77-8,82$; Indian alarm in Massachusetts, $85^{-8}$

Jamaica, at the revolution, 39 ; French war, 63, 68, 73, 92-3; under Albemarle, 139; Inchiquin, 140; Beeston, I40-2; trade in, 164

James II, Colonial policy of, 11,42 , 98

Jesuits, 76

Johnson, Sir Nathaniel, 39

Jones, Cadwallader, 145, 167

Justice, state of, in the Colonies, 121 , 138

Kendall, James, Governor of Barbados, $38,59,62-7,72,136-7$

Larkin, George, 164

Leeward Islands, at the revolution, 39 ; and the war, 59-65, 72-3, 945 ; trade laws, 167

Leisler, Jacob, in New York, 27; accession to power, 30 ; and Albany, 3I; war measures, 48; Senectady, 49; Quebec expedition, $5 \mathrm{I}$; arrest and execution, 32

Leislerite party, 32, 79, I I0, I I9, I 27-8

Le Roux, Bartholomew, 28

Lillingston, Colonel, 70

Linen manufacture, 177

Livingston, $30,49,84,89$

Locke, John, soo

Lords Justices, 89

Magna Carta, referred to, I I 5, I36

Maine, 90

Manikin Town, Huguenots at, I I 2-3

Manufactures, 1 76-8

Maquas, 49

Markham, William, I07-9, I 62

Martinique, attacks on, $63-4,67$

Maryland, revolution in, 32 ; and quotas, 58, 77-9; Copley in, I I4; Nicholson in, I14; constitutional affairs in, 11 4-6; illegal trade in, 158; manufactures, I 77

Massachusetts, under Charles I, 7; revolution in, I4 et seq.; charter, 22 et seq., 122; Quebec expedition, $5 \mathrm{I}$; attitude in defence, $75,78,90$, 92,95 ; appeals to the King, $81-2$; French claims in Nova Scotia, 84 ; under Phips, 103-7; illegal trade in, 156

Mather, Cotton, 19, 23

Methuen, John, IO I

Milborne, 32

Mohawks, 48

Molesworth, Governor of Jamaica, 40

Monmouth rebels, 165

Montgomery, Sir Thomas, 38

Montserrat, 59, 95, I33 
Nanfan, Lieut.-Governor of New York, 91

Naval officer, 10

- stores, 174

Navigation Laws, I50-173; beginnings, 3 ; during the revolution, 21 ; under William III, I52-4; illegal trade, I 56-68

Nevill, Admiral, 73-4

Nevis, 6o-1, 63, 132-6

Newichewarnock, 49

New England, united under Andros, I I ; under Bellomont, I I 8-9; copper mines in, I74

Newfoundland, 46

New Hampshire, 25, 56, 75, 8I, 90, 123-5

New Jersey, at the revolution, 37; defence in, $8 \mathrm{I}$; proprietors of, 128 et seq.

New York, revolution in, 26 et seq.; beginning of war, 48; Quebec expedition, $5 \mathrm{I}$; defence in, 82,88 ; illegal trade in, 160

Nicholson, Francis, Lieut.-Governor of New York, 26; at the revolution, 26 et seq.; Lieut.-Governor of Virginia, 37, 52, I1 2; Governor of Maryland, 80, 159 ; inquiry into conduct of, III; Governor of Virginia, 91, II3; fight with pirates, 164

Nova Scotia, 84

Onondagas, $48,86-7,89$

Oyster river, 77

Partridge, Lieut.-Governor, 124

Pemaquid, 47, 57, 90

Penn, William, at the revolution, 32 ; warns Fletcher, 56, 107; and defence, 9I ; proprietorship, 108, I 29

Pennicooks, 87

Pennsylvania, at the revolution, 37 ; protests against condition of New York, 53 ; defence in, 53,8I ; under Fletcher, 56 ; and quotas, 58,76 , 89,91 ; illegal trade in, I 59, I6 1

Perth Amboy, 128 et seq.

Petit Guavos, 92

Phips, Sir William, early life, 26, 103; in England, 23; Governor of Massachusetts, 15, 26; expedition to Port Royal, 50; and Quebec, 51 ; suggests another expedition, 53; and Usher, 57, 105; and Wheler, 74, 102; relations with Fletcher, 75 , 104; his governorship, 103-7, I 57
Pirates, 162-4

Piscataqua country, $5 \mathrm{I}, \mathrm{I} \circ 5$

Political situation in the colonies, I 46-9

Pollexfen, John, 101, I 38

Port Royal, 50, 84

Powle, Henry, roo

Proprietary governments, 128-3 I, 148

Quakers, in Pennsylvania, 37-8, 97, I08

Quary, Colonel, 129, I6I

Quebec, expedition of $1690,22,26$, 5I, 74-5

Quotas, system of, 56, 77, 91-2

Randolph, Edward, Surveyor of Customs, II, 169; imprisoned at the revolution, 14; gives reasons for revolt, 18 ; describes preparations for war, 45 ; imprisoned in Bermuda, 144, 168; on illegal trade, I 56, I 58 et seq.; Scottish proposals, I7I; on naval stores, 175

Revolution, English, its importance in the Colonies, $40-3$

Revolutions in the Colonies, 13 ; in Boston, 13 ; in New York, 26; in Maryland, 32

Rhode Island, 27, 57, 79; appeals to the King, 82; and Phips, 105; under Bellomont, I 26-7; illegal trade in, 157

Richier, Isaac, I43-5, 168

Robinson, Governor of Bermuda, 143

Russell, Edward, 100

Russell, Governor of Barbados, 73, I 37

Ryswick, Peace of, 74, 82-3

Sacraments Act, in Barbados, $136-7$

St Eustatia, 62

St Kitts, 59-61, 63, 65, 92-5

St Lucia, 93

Salmon Falls, 49

Scotland, and illegal trade, 160,170 ; Darien scheme, $17 \mathrm{I}-3$

Selwyn, William, Governor of Jamaica, 94, 142

Senectady, 31, 49, 80, 89

Sharp, William, I69-70

Sloughter, Colonel, Governor of New York, 28, 31, 52-4

Spain, relations with, I52, I72

Stede, William, Deputy-Governor of Barbados, 38, 59, 6I 
Tankerville, Earl of, 100

Thornhill, Sir Timothy, 63-5

Tobago, French claims on, 93

Trott, Nicholas, Governor of the Bahamas, 145

Usher, James, 56, 76, 81, 124

Virginia, at the revolution, $36,4 \mathrm{I}$; defence in, $52,76-9,91,1$ I 2 ; under Andros, III -3 ; illegal trade in, I 59

Watson, Sir Francis, I 39

Webb, Governor of the Bahamas, 146

Weems, Lieutenant, 47

West Indies, at the revolution, 40; war in, 59-74; during peace, $92-5$ political affairs in, 131-46; trade laws in, 164-70

Wheler, Admiral, 65-8, 74-5, 102

William III, proclamation to the Colonies, I $_{3}$; appoints governor of Massachusetts, 24; his colonial position in 1689,42 ; declares war on France, 46; war policy in America, 95-8; Committees of Trade, 100

William and Mary College, II 2

Wilmot, Admiral, 70-1

Winthrop, Colonel, 5 I

Witchcraft, $103-4$

Woollen industry, $177-8$

Wrenn, Captain, 66

Wright, Captain, 62, 64-5 


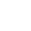





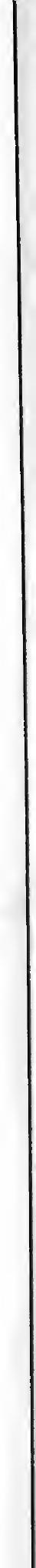






\section{University of Teronto Library}

\section{DO NOT}

\section{REMOVE}

THE

GARD

\section{FROM}

THIS

POGKET

Acme Library Card Pocket

Under Pat. "Ref. Index Fuls" Made by LIBRARY BUREAU 
